\title{
Comparison of heavy-duty diesel engine emissions between an on-road route and engine dynamometer simulated on-road cycle
}

John Curtis Gibble

West Virginia University

Follow this and additional works at: https://researchrepository.wvu.edu/etd

\section{Recommended Citation}

Gibble, John Curtis, "Comparison of heavy-duty diesel engine emissions between an on-road route and engine dynamometer simulated on-road cycle" (2003). Graduate Theses, Dissertations, and Problem Reports. 1349.

https://researchrepository.wvu.edu/etd/1349

This Thesis is protected by copyright and/or related rights. It has been brought to you by the The Research Repository @ WVU with permission from the rights-holder(s). You are free to use this Thesis in any way that is permitted by the copyright and related rights legislation that applies to your use. For other uses you must obtain permission from the rights-holder(s) directly, unless additional rights are indicated by a Creative Commons license in the record and/ or on the work itself. This Thesis has been accepted for inclusion in WVU Graduate Theses, Dissertations, and Problem Reports collection by an authorized administrator of The Research Repository @ WVU. For more information, please contact researchrepository@mail.wvu.edu. 
Comparison of Heavy-Duty Diesel Engine Emissions Between an On-Road Route and Engine Dynamometer Simulated On-Road Cycle

John Curtis Gibble

Thesis submitted to

The College of Engineering and Mineral Resources at

West Virginia University

In partial fulfillment of the requirements

for the degree of

Master of Science

In

Mechanical Engineering

Advisory Committee Members:

Gregory J. Thompson, Ph.D., Chair

Nigel N. Clark, Ph.D.

Mridul Gautam, Ph.D.

Department of Mechanical and Aerospace Engineering

West Virginia University

2003

Keywords: In-use Emissions, Engine Testing, Diesel Engines, Mobile Emissions, Fuel Properties, Operating Conditions 


\section{Abstract \\ Comparison of Heavy-Duty Diesel Engine Emissions Between an On-road Route and Engine Dynamometer Simulated On-road Cycle}

\section{John Curtis Gibble}

Heavy-duty diesel engines are known to emit concentrations of harmful compounds of oxides of nitrogen $\left(\mathrm{NO}_{\mathrm{x}}\right)$ and particulate matter $(\mathrm{PM})$. As a means of emissions control, engine dynamometer certification is currently employed. Current certification cycles provide for standardized comparisons, but may not be indicative of real-world emissions. Accurate in-use emissions testing would provide more realistic engine emissions values.

To examine the accuracy of the West Virginia University Mobile Emissions Measurement System (MEMS), on-road emissions tests were performed with six different diesel-powered vehicles. Exhaust species measured by MEMS were $\mathrm{NO}_{\mathrm{x}}$ and $\mathrm{CO}_{2}$, reported on a brake-specific basis. Information obtained during on-road emissions tests was implemented in the creation of a simulated in-use engine dynamometer cycle, and the system was compared against an engine dynamometer laboratory.

The ability to accurately generate an in-use driving cycle for an engine dynamometer was studied, and variables affecting route repeatability were measured. Testing on an engine dynamometer found fuel and operating conditions can independently vary $\mathrm{NO}_{\mathrm{x}}$ emission by $10 \%$, and $\mathrm{PM}$ emission by $30 \%$. In-use route variation of inferred work was $2.8 \%, 6.0 \%$ for $\mathrm{NO}_{\mathrm{x}}$, and $1.8 \%$ for $\mathrm{CO}_{2}$.

The ability of MEMS to measure emissions was determined by comparison with laboratory grade analyzers. The MEMS system was on average within $0.4 \%$ of laboratory measured work, $5.3 \%$ of laboratory measured emissions of $\mathrm{NO}_{\mathrm{x}}$, and $6.1 \%$ of laboratory measured $\mathrm{CO}_{2}$ concentrations. 


\section{Table of Contents}

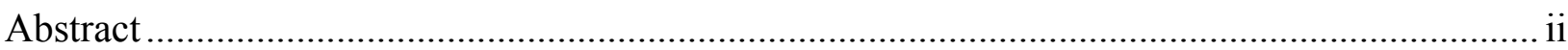

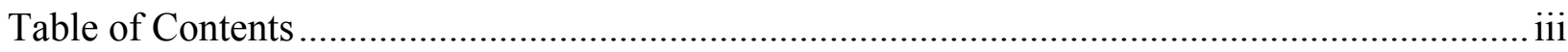

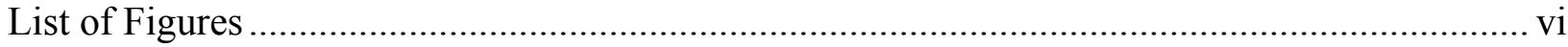

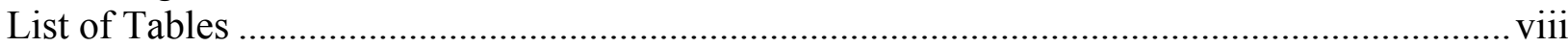

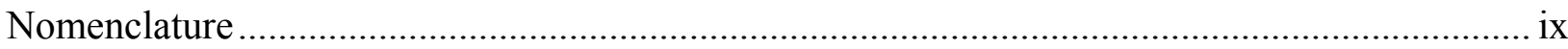

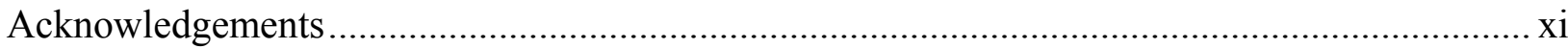

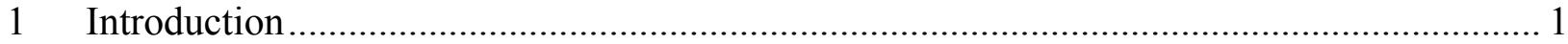

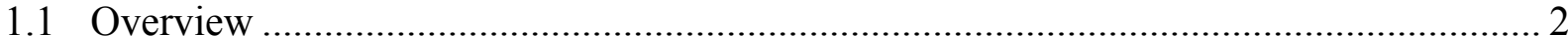

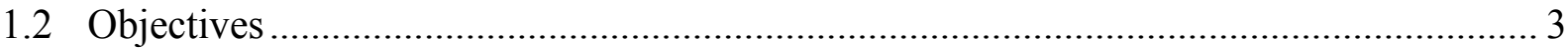

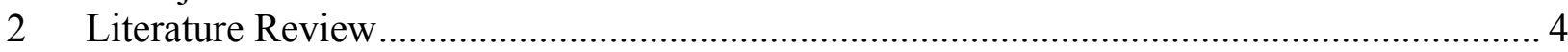

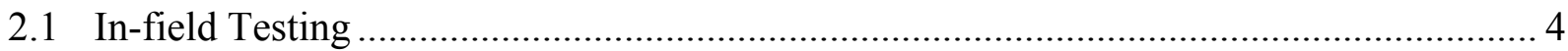

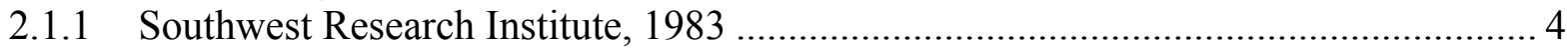

2.1.2 Michigan Technical University, 1992 ................................................................... 4

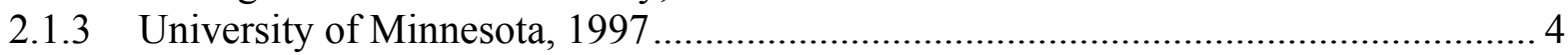

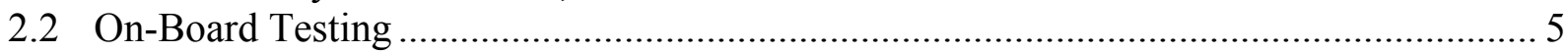

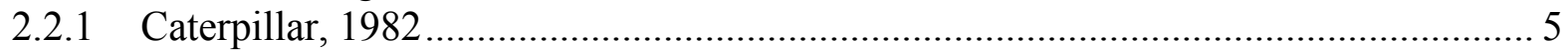

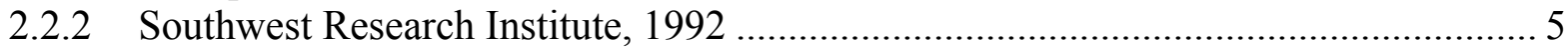

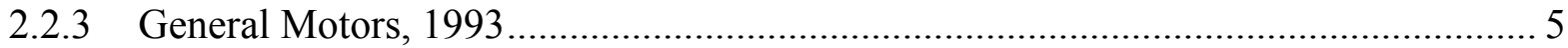

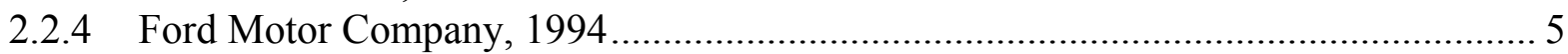

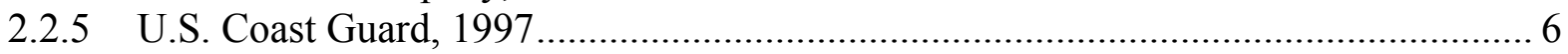

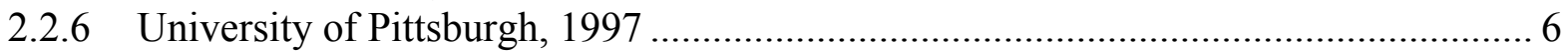

2.2.7 The Flemish Institute for Technological Research (VITO), 1997 ………….............. 6

2.2.8 Northeast States for Coordinated Air Use Management (NESCAUM), 1998_............. 7

2.2.9 Office of Mobile Sources: US-EPA, 1999 …………............................................. 7

2.2.10 Ford Motor Company and WPI-Microprocessor Systems, Inc., 1999 .......................... 7

2.2.11 Horiba, Ltd. and NGK Insulators, 2000 ……….................................................. 7

2.2.12 University of California, Riverside, and Honda R\&D, 2000 ……............................ 8

2.2.13 EPA - On-Road Diesel Emissions Characterization (ODEC), 2002 ………................. 8

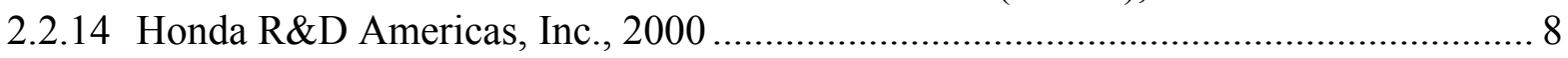

2.2.15 Technical Research Center of Finland (VTT Energy), 2001 ..................................... 9

2.2.16 Clean Air Technologies International, 2001 ........................................................ 9

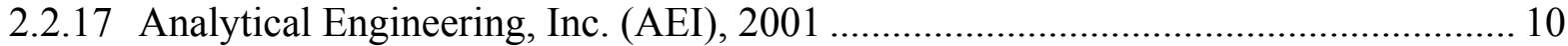

2.2.18 Engine, Fuel, and Emissions Engineering, Inc., 2001............................................ 11

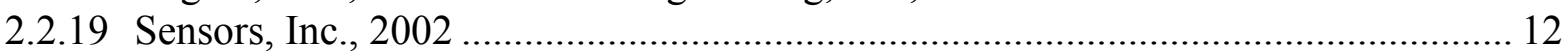

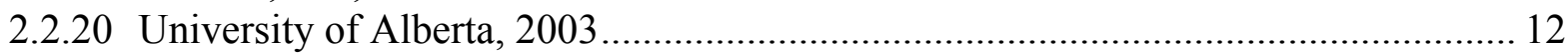

2.3 Previous Assessments of the Impact of Fuel and Operating Conditions on Emissions and

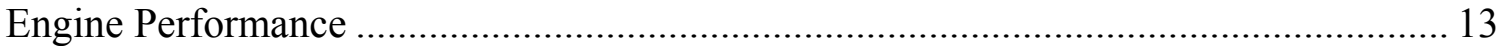

3 Experimental Procedures and Equipment .................................................................. 16

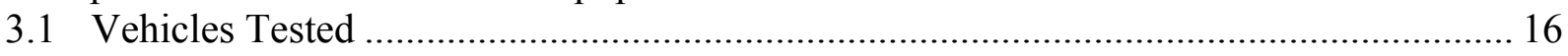

3.2 Engine and Emissions Research Laboratory …………................................................. 16

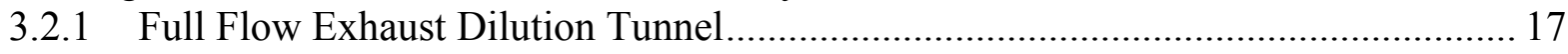

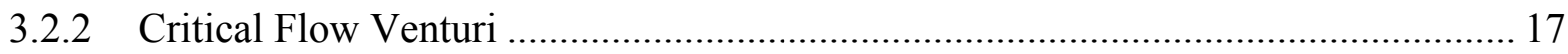

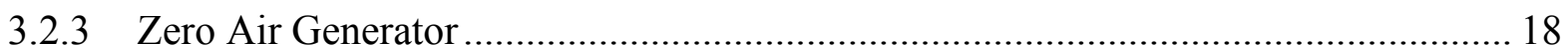




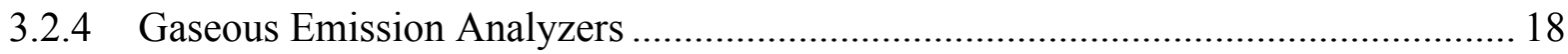

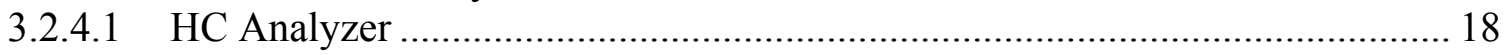

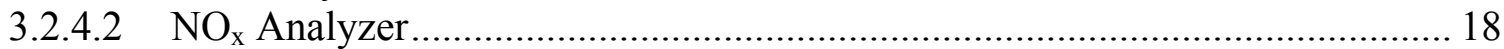

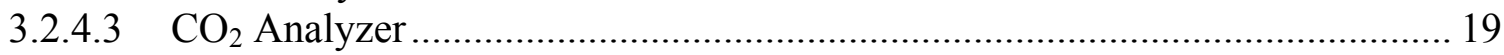

3.2.4.4 Carbon Monoxide (CO) Analyzer ........................................................... 19

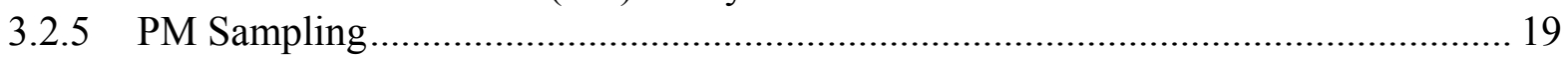

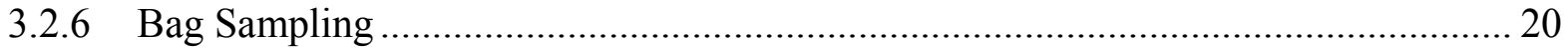

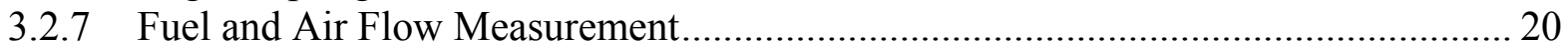

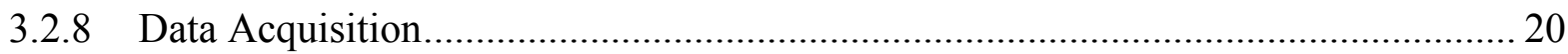

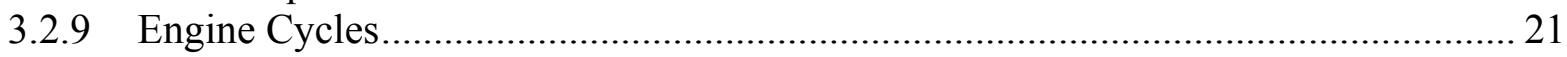

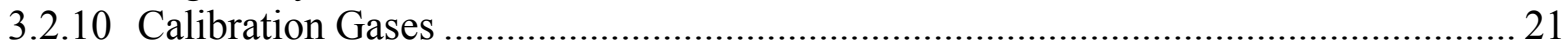

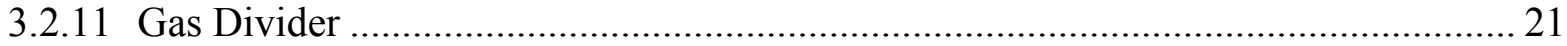

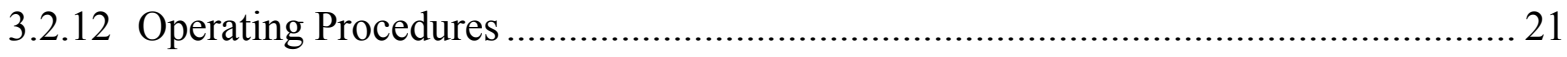

3.3 Mobile Emissions Measurement System (MEMS) ………………............................. 22

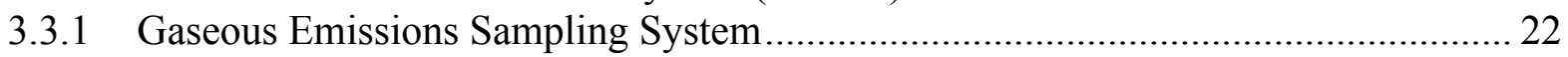

3.3.1.1 Probe and Heated Sampling Line ………............................................... 23

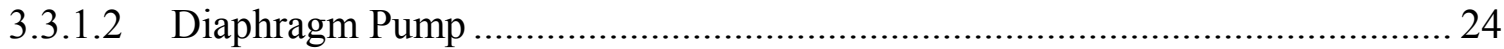

3.3.1.3 Sampling System Temperature Measurements................................................ 24

3.3.1.4 Calibration and Calibration Gasses............................................................ 24

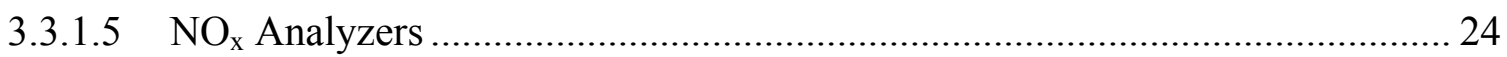

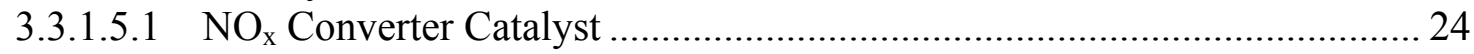

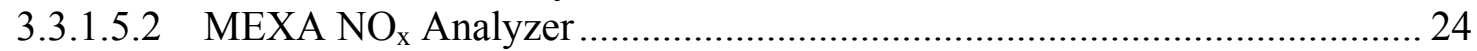

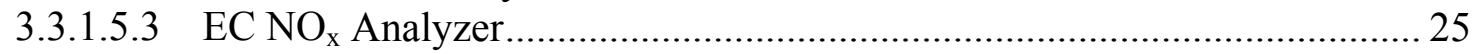

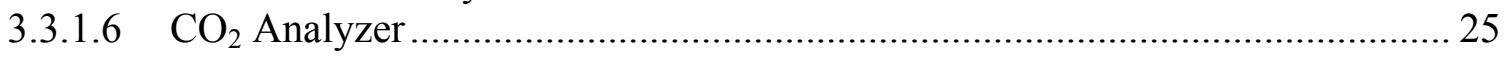

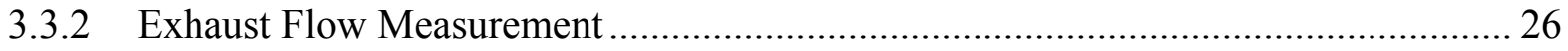

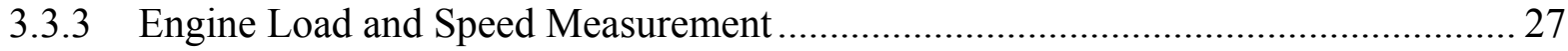

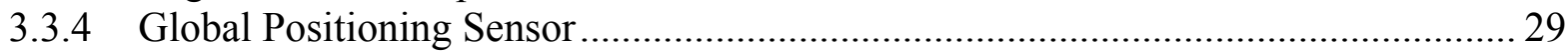

3.3.5 Ambient Condition Measurement ......................................................................... 29

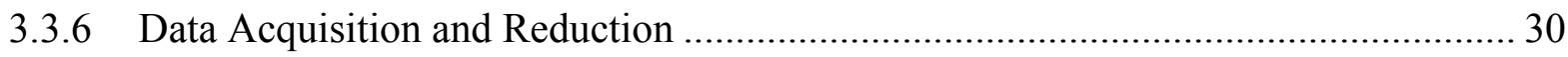

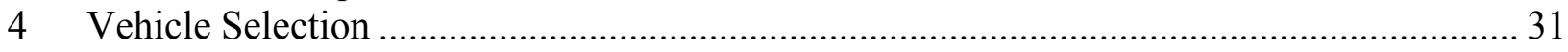

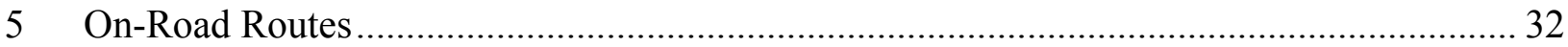

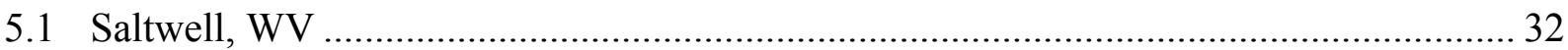

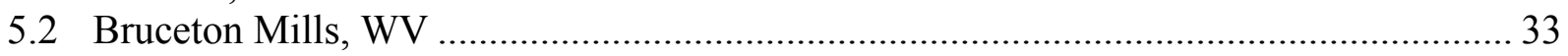

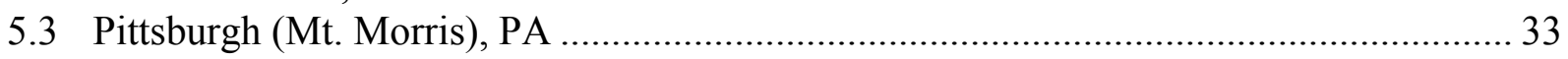

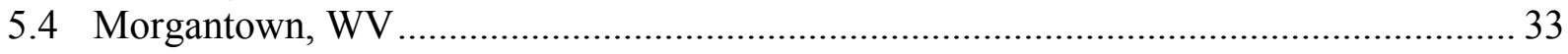

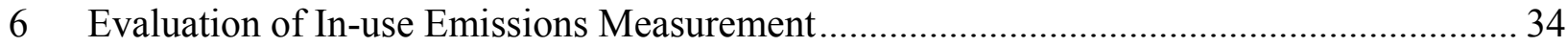

6.1 Variation of Vehicle Emissions for On-road Driving Cycles .......................................... 34

6.2 Dynamometer Cycles and Corresponding On-Road Cycles ……………........................ 35

6.3 Comparison of Engine Dynamometer and Mobile Emissions Measurement System...... 36

6.4 Factors Effecting Engine Performance and Emissions ……………................................... 37

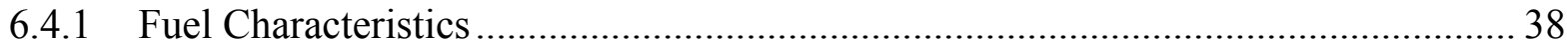

6.4.1.1 Olefins, Aromatics, and Saturates................................................................ 39

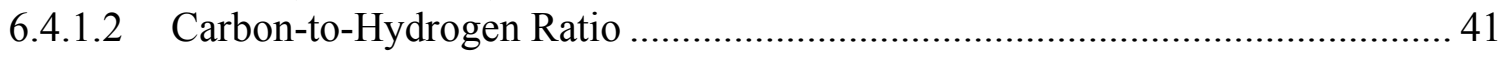

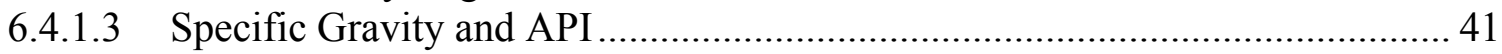

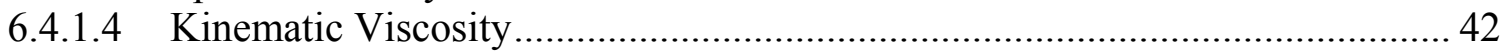

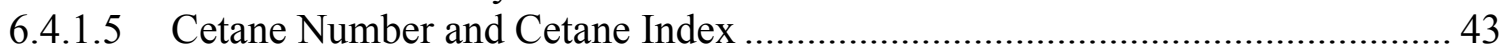




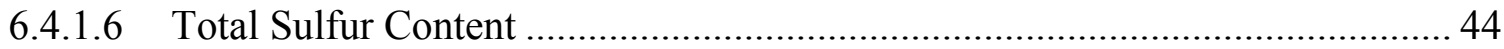

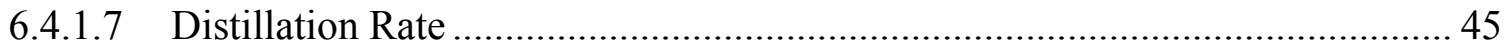

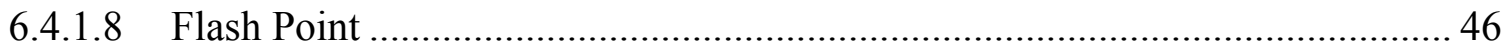

6.4.2 Effects of Fuel Properties on Performance and Emissions ........................................ 46

6.4.2.1 Fuel Property Emissions Variance................................................................ 46

6.4.2.1.1 Fuel Specific Carbon-Oxide Emissions ................................................... 46

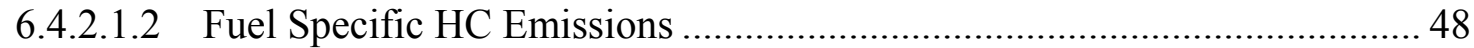

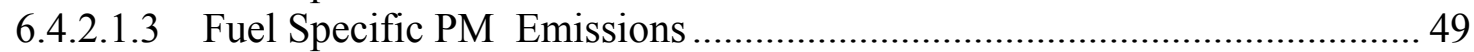

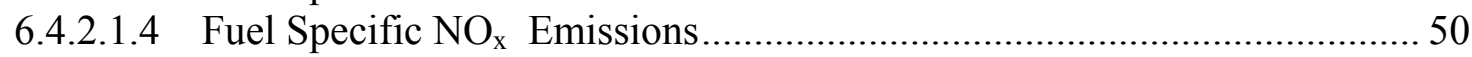

6.4.2.1.5 Fuel Specific Work Output ...................................................................... 50

6.4.2.2 Relationships Between Fuel Property and Emissions........................................5 51

6.4.3 Effects of Engine Operating Conditions on Performance and Emissions................... 55

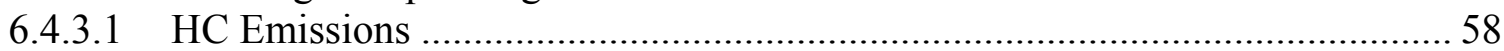

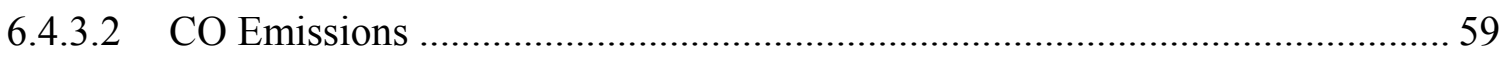

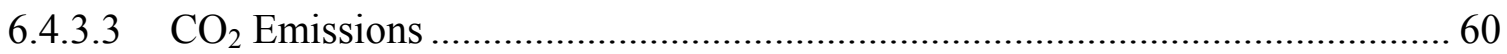

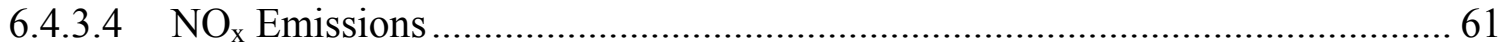

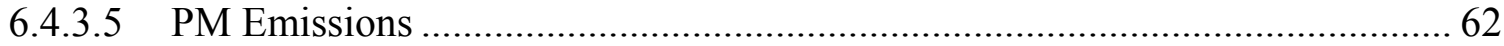

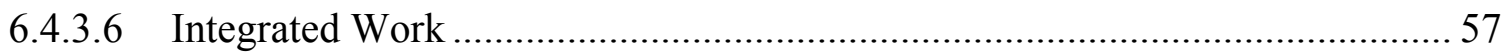

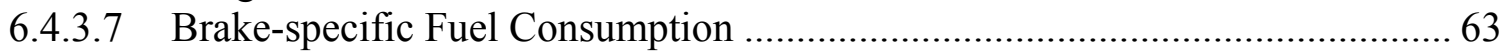

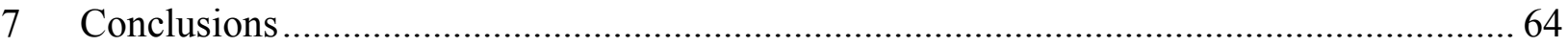

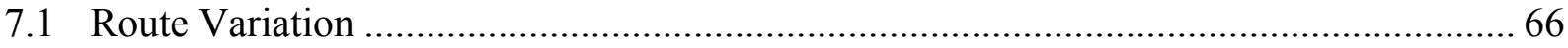

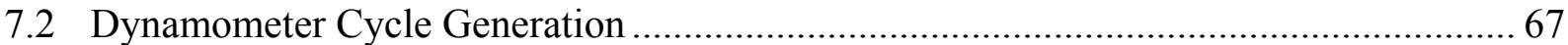

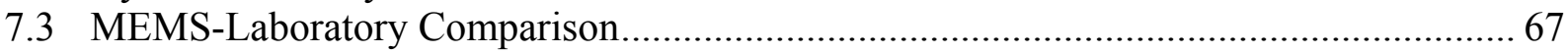

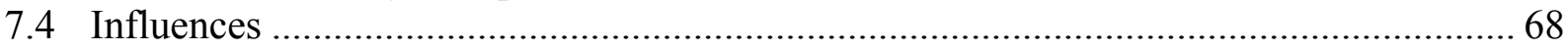

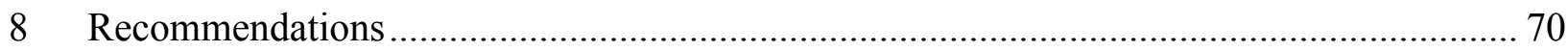

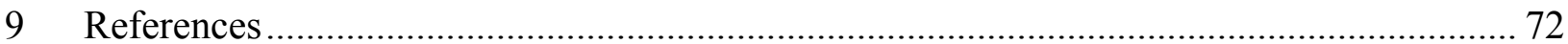

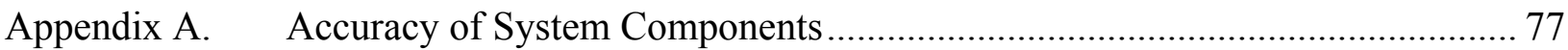

Appendix B. WVU EERC HDDE Emissions Laboratory Schematic....................................... 78

Appendix C. Results of Analytical Fuel Property Tests .......................................................... 79

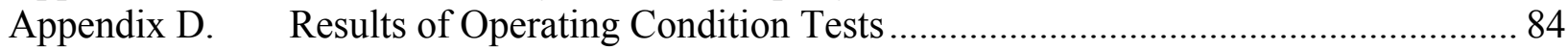

Appendix E. Data Correlation Analysis.............................................................................. 88

Appendix F. Continuous On-Road and Test Cell Data .......................................................... 94 


\section{List of Figures}

Figure 3-1: MEMS Data Acquisition and Emissions Measurement Components. Left

Hand Module is the Data Acquisition System; Right Hand Module is the Emission

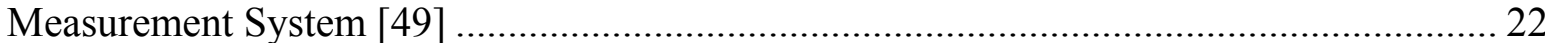

Figure 3-2: MEMS Sample Flow Schematic [49] …............................................................ 23

Figure 3-3: Raw Exhaust Gas Sampling Probe [2] .............................................................. 23

Figure 3-4: Annubar Flow Measurement Device [52] ....................................................... 26

Figure 3-5: Example of Generated Engine Lug Curve ...................................................... 28

Figure 3-6: Graphical Definition of NTE Zone for Gaseous Emissions [3] ............................. 29

Figure 6-1 Example of Continuous Diesel Engine $\mathrm{NO}_{\mathrm{x}}$ Emission Measurement From

MEXA, EC, and Laboratory Analyzers for SAB2BM Dynamometer Cycle ..................... 37

Figure 6-2: Aromatic Content of Fuels Tested ..................................................................... 41

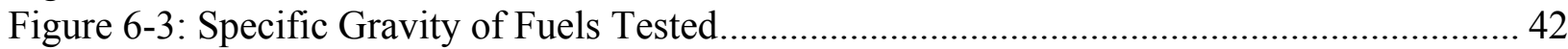

Figure 6-4: Cetane Number and Cetane Index of Fuels Tested............................................ 43

Figure 6-5: Total Sulfur Content in of Fuels Tested........................................................... 44

Figure 6-6: Temperature for Multiple Distillation Recovery Points of Fuels Tested................. 45

Figure 6-7 Effects of Fuel on Sample Diesel Engine Average Brake-specific HC

Emissions for SAB2BM Cycle on WVU DC Dynamometer ............................................ 48

Figure 6-8: Effects of Fuel on Sample Diesel Engine Average Brake-specific PM

Emissions for Simulated SAB2BM Cycle on WVU DC Dynamometer ........................... 49

Figure 6-9: Effects of Fuel on Sample Diesel Engine Average Brake-specific $\mathrm{NO}_{\mathrm{x}}$

Emissions for SAB2BM Cycle on WVU DC Dynamometer ......................................... 50

Figure 6-10: Sample Diesel Engine $\mathrm{NO}_{\mathrm{x}}$ Emission as a Function of Aromatic Content for

SAB2BM Cycle on WVU DC Dynamometer .................................................................. 52

Figure 6-11: Sample Diesel Engine CO, HC, and PM Emission as a Function of Specific

Gravity for SAB2BM Cycle on WVU DC Dynamometer ................................................ 53

Figure 6-12: Sample Diesel Engine $\mathrm{HC}, \mathrm{CO}, \mathrm{PM}$, and $\mathrm{NO}_{\mathrm{x}}$ Emissions as a Function of

Cetane Number for SAB2BM Cycle on WVU DC Dynamometer .................................. 54

Figure 6-13: Sample Diesel Engine $\mathrm{HC}, \mathrm{NO}_{\mathrm{x}}$, and PM Emissions as a Function of $\mathrm{T} 95$

Distillation for SAB2BM Cycle on WVU DC Dynamometer.......................................... 55

Figure 6-14: Effects of Operating Conditions on Sample Diesel Engine Brake-specific

HC Emissions for SAB2BM Cycle on WVU DC Engine Dynamometer ......................... 58

Figure 6-15: Effects Operating Conditions on Sample Diesel Engine Brake-specific CO

Emissions for SAB2BM Cycle on WVU DC Engine Dynamometer................................. 59

Figure 6-16: Effects of Engine and Ambient Conditions on Brake-specific CO2

Emissions for Simulated Bruceton Mills On-Road Cycle on WVU DC Engine

Dynamometer....

Figure 6-17: Effects of Engine and Ambient Conditions on Brake-specific NOx

Emissions for Simulated Bruceton Mills On-Road Cycle on WVU DC Engine

Dynamometer

Figure 6-18: Effects of Engine and Ambient Conditions on Brake-specific PM Emissions

for Simulated Bruceton Mills On-Road Cycle on WVU DC Engine Dynamometer ........... 62

Figure 6-19: Effects of Engine and Ambient Conditions on BSFC for Simulated Bruceton

Mills On-Road Cycle on WVU DC Engine Dynamometer. 
Figure 7-1: Method for Calculation of Values in Comparison Analysis 64

Figure 7-2: Average Variance in Diesel Engine Work and Emission Measurement for

SAB2BM Cycles for Engines Tested on Dynamometer. 65

Figure 7-3: Maximum Variance in Diesel Engine Work and Emission Measurement for

SAB2BM Cycles for Engines Tested on Dynamometer. 66

Figure 7-4: Influence of ECU on Engine $\mathrm{NO}_{\mathrm{x}}$ Emissions During Sample HDDE Engine Dynamometer SAB2BM Cycle 69

Figure B-1: WVU EERC HDDE Emissions Laboratory Schematic [3].................................... 78

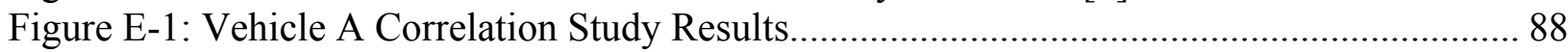

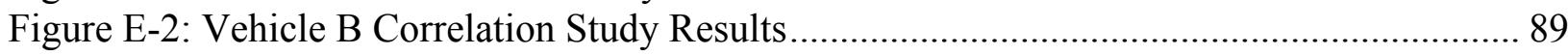

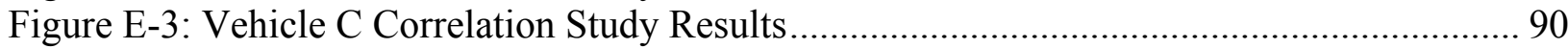

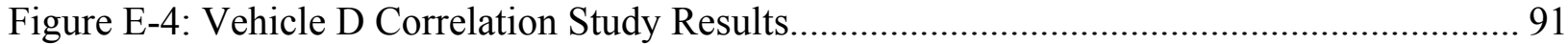

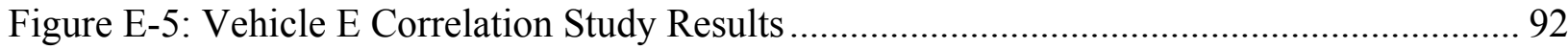

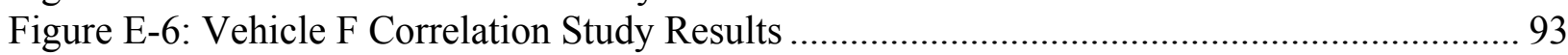

Figure F-1: Continuous Torque In-use Versus In-cell Sab2BM Comparison ............................... 94

Figure F-2: Continuous Power In-use Versus In-cell Sab2BM Comparison ................................. 95

Figure F-3: Continuous $\mathrm{CO}_{2}$ In-use Versus In-cell Sab2BM Comparison..................................... 96

Figure F-4: Continuous Engine Speed In-use Versus In-cell Sab2BM Comparison...................... 97

Figure F-5: Continuous Exhaust Flowrate In-use Versus In-cell Sab2BM Comparison................ 98

Figure F-6: Continuous Exhaust Temperature In-use Versus In-cell Sab2BM Comparison ....... 99

Figure F-7: Uncorrected Continuous $\mathrm{NO}_{\mathrm{x}}$ Emission In-use Versus In-cell Sab2BM ................. 100

Figure F-8: Corrected Continuous $\mathrm{NO}_{\mathrm{x}}$ Emission In-use Versus In-cell Sab2BM ..................... 101 


\section{List of Tables}

Table 1-1: HDDE On-road Emission Standards (g/Bhp-Hr) [1] ........................................... 1

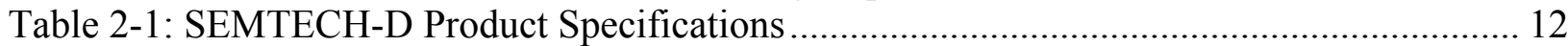

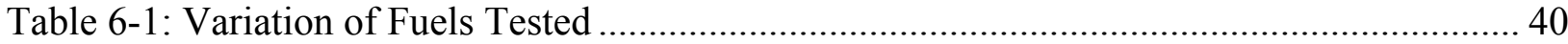

Table 6-2: Integrated Results and Variation Analysis of Fuel Type Experiment for

Sample Diesel Engine on SAB2BM Dynamometer Cycle .............................................. 47

Table 6-3: Operating Condition Study Test Ranges Set Points................................................. 56

Table 6-4: Average Measured Air Mass, Intake Air Temperature and Manifold

Temperature for Operating Condition Study ............................................................ 57

Table 6-5: Integrated Results and Variation Analysis of Operating Condition Experiment

for Sample Diesel Engine on SAB2BM Dynamometer Cycle ........................................ 57

Table 7-1: Effects of 60 Second Idle Present in MEMS on Work and Emissions

Measurements for Sample Diesel Engine SAB2BM Dynamometer Cycle......................... 68

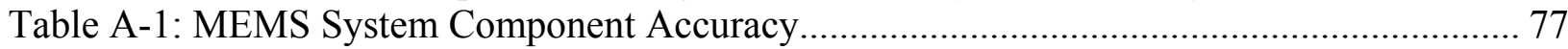

Table A-2: Laboratory Test Cell Component Accuracy ..................................................... 77

Table C-1: CARB Fuel Analytical Report.............................................................................. 79

Table C-2: Mt. Morris Citgo Fuel Analytical Report .......................................................... 80

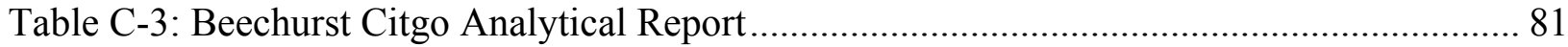

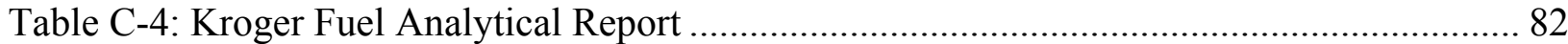

Table C-5: Guttman Fuel Analytical Report................................................................. 83

Table D-1: Results of Diesel Engine Work and Emission Measurements for Fuel

Temperature Study on SAB2BM Cycles on WVU DC Dynamometer ............................. 84

Table D-2: Results of Diesel Engine Work and Emission Measurements for Intercooler

Temperature Study on SAB2BM Cycles on WVU DC Dynamometer .............................. 85

Table D-3: Results of Diesel Engine Work and Emission Measurements for Intake Air

Temperature Study on SAB2BM Cycles on WVU DC Dynamometer ............................. 86

Table D-4: Results of Diesel Engine Work and Emission Measurements for Engine

Restriction Study on SAB2BM Cycles for on WVU DC Dynamometer ........................... 87

Table E-1: Vehicle A Integrated Data From Test Record ................................................ 88

Table E-2: Vehicle B Integrated Data From Test Record..................................................... 89

Table E-3: Vehicle C Integrated Data From Test Record.................................................... 90

Table E-4: Vehicle D Integrated Data From Test Record ..................................................... 91

Table E-5: Vehicle E Integrated Data From Test Record.................................................. 92

Table E-6: Vehicle F Integrated Data From Test Record ................................................... 93 


\section{Nomenclature}

\begin{tabular}{|c|c|}
\hline$\eta$ & Efficiency \\
\hline$\Delta \mathrm{P}$ & Differential Pressure \\
\hline $\mathrm{A} / \mathrm{F}$ & Air-to-Fuel Ratio \\
\hline AEI & Analytical Engineering, Inc. \\
\hline API & American Petroleum Institute \\
\hline Bhp & Brake-horsepower \\
\hline BSFC & Brake Specific Fuel Consumption \\
\hline CAI & California Analytical Instruments \\
\hline CARB & California Air Resources Board \\
\hline CE-CERT & $\begin{array}{l}\text { College of Engineering-Center for Environmental Research and } \\
\text { Technology }\end{array}$ \\
\hline CFR & Code of Federal Regulations \\
\hline $\mathrm{CI}$ & Compression Ignited \\
\hline CLA & Chemiluminescent Analyzer \\
\hline $\mathrm{CNC}$ & Condensation Nucleus Counter \\
\hline $\mathrm{CNG}$ & Compressed Natural Gas \\
\hline $\mathrm{CO}$ & Carbon Monoxide \\
\hline $\mathrm{CO}_{2}$ & Carbon Dioxide \\
\hline $\mathrm{COV}$ & Coefficient of Variation \\
\hline CVS & Constant Volume Sampling \\
\hline $\mathrm{D}$ & Inner Pipe Diameter \\
\hline EAMP & Emissions-assisted Maintenance Procedure \\
\hline EC & Electrochemical \\
\hline ECU & Electronic Control Unit \\
\hline EERC & Engine and Emissions Research Center \\
\hline EPA & Environmental Protection Agency \\
\hline $\mathrm{F}_{\mathrm{AA}}$ & Thermal Expansion Correction Factor \\
\hline $\mathrm{F}_{\mathrm{G}}$ & Specific Gravity Factor \\
\hline FID & Flame Ionization Detector \\
\hline $\mathrm{F}_{\mathrm{L}}$ & Location Correction Factor \\
\hline $\mathrm{F}_{\mathrm{M}}$ & Manometer Correction Factor \\
\hline $\mathrm{F}_{\mathrm{NA}}$ & Unit Conversion Factor \\
\hline $\mathrm{F}_{\mathrm{PB}}$ & Temperature Correction Factor \\
\hline $\mathrm{F}_{\mathrm{RA}}$ & Reynolds Number Correction Factor \\
\hline $\mathrm{F}_{\mathrm{TF}}$ & Flowing Temperature Correction Factor \\
\hline FTIR & Fourier Transform Infrared \\
\hline FTP & Federal (Transient) Test Procedure \\
\hline $\mathrm{g}$ & Grams \\
\hline GPS & Global Positioning Sensor \\
\hline GVWR & Gross Vehicle Weight Restricted \\
\hline $\mathrm{HC}$ & Hydrocarbon \\
\hline HDDE & Heavy-Duty Diesel Engine \\
\hline HEPA & High Efficiency Particulate Arresting \\
\hline
\end{tabular}




\begin{tabular}{|c|c|}
\hline HFID & Heated Flame Ionization Detector \\
\hline $\mathrm{Hr}$ & Hour \\
\hline I & Current \\
\hline $\mathrm{K}$ & Flow Coefficient \\
\hline $\mathrm{k}$ & Isentropic Gas Constant \\
\hline LFE & Laminar Flow Element \\
\hline NDIR & Non-dispersive Infrared \\
\hline NDUV & Non-dispersive Ultraviolet \\
\hline NESCAUM & Northeast States for Coordinated Air Use Management \\
\hline NIST & National Institute of Standards and Technology \\
\hline NMHC & Non-Methane Hydrocarbon \\
\hline NO & Nitric Oxide \\
\hline $\mathrm{NO}_{2}$ & Nitrogen Dioxide \\
\hline $\mathrm{NO}_{\mathrm{x}}$ & Oxides of Nitrogen \\
\hline NTE & Not-to-Exceed \\
\hline $\mathrm{O}_{2}$ & Oxygen \\
\hline OBD & On Board Diagnostic \\
\hline ODEC & On-Road Diesel Emissions Characterization \\
\hline PAH & Polycyclic Aromatic Hydrocarbon \\
\hline $\mathrm{P}_{\mathrm{F}}$ & Absolute Pressure \\
\hline PM & Particulate Matter \\
\hline PREVIEW & $\begin{array}{l}\text { Portable Real-Time Emission Vehicular Integrated Engineering } \\
\text { Workstation }\end{array}$ \\
\hline$Q$ & Volumetric Flow Rate \\
\hline$\dot{Q}$ & Mass Flow Rate \\
\hline $\mathrm{QA} / \mathrm{QC}$ & Quality Assurance/ Quality Control \\
\hline RAVEM & Ride Along Vehicle Emissions Measurement System \\
\hline ROVER & Real-time On-road Vehicle Emissions Reporter \\
\hline SAB2BM & Sabraton to Bruceton Mills \\
\hline SI & Spark-Ignited \\
\hline $\mathrm{SO}_{2}$ & Sulfur Dioxide \\
\hline S-HDDE & Settling Heavy-Duty Diesel Engine Manufacturers \\
\hline SRM & Standard Reference Material \\
\hline $\mathrm{T}$ & Temperature \\
\hline TEOM & Tapered Element Oscillating Microbalance \\
\hline THC & Total Hydrocarbons \\
\hline ULEV & Ultra-Low Emission Vehicle \\
\hline $\mathrm{V}$ & Voltage \\
\hline VITO & Flemish Institute for Technological Research \\
\hline VOEM & Vito's On-the-road Emission and Engine Measurement \\
\hline WVU & West Virginia University \\
\hline $\mathrm{Y}_{\mathrm{A}}$ & Gas Expansion Factor \\
\hline $\mathrm{ZrO}_{2}$ & Zirconium Oxide \\
\hline
\end{tabular}




\section{Acknowledgements}

I would like to take the chance to thank those who have helped to guide both this work and my life. The foundation of this thesis was laid by my advisor, Greg Thompson. Your technical advice and guidance are unparalleled, and you have taught me how to be an efficient and effective engineer. Dr. Gautam, you have not only helped teach me how to be successful, but how to enjoy what I do. And Dr. Clark, you have made an extreme impact on my professional and personal development. You are well respected by all who meet you, and your generosity knows no bounds.

I also want to thank my friends and co-workers without whom it would have been impossible to complete this work in only one years time: Dan Carder and Wes Riddle, Tom Spencer, Ron Jarrett, and all other graduate students and hourly workers who make things happen at the EERC; especially Axel Radermacher. Hopefully this work will be as much help to future grad students as past works were of aide to me.

My family has installed in me good faith and ethics; which have led to my current and future accomplishments. To my mother, father, and brother: you are the reason I am who I am today.

To my beautiful wife, Lauren: I thank you for letting me work the long hours, and supporting my dreams. The picture of you on my desk will always remind me what is important in life. I thank you for the lunches you prepare, and for the check-in phone calls. I will always love you, and I will always find time to be with you.

Opportunity is missed by most people because it is dressed in overalls and looks like work.

-Thomas Edison 


\section{Introduction}

Diesel engines have a significant negative impact on the environment, producing several toxic and carcinogenic substances. Exhaust constituents of particular interest are the nitrogenoxygen compounds nitric oxide (NO) and nitrogen dioxide $\left(\mathrm{NO}_{2}\right)$ (together identified as $\mathrm{NO}_{\mathrm{x}}$ ), and particulate matter (PM). The U.S. Environmental Protection Agency (EPA) and the California Air Resources Board (CARB) were charged with the task of regulating emissions to protect the environment, and continue refining and tightening their legislations to the stringent levels accepted for 2007 [1]. The history and future of heavy-duty diesel emissions standards are displayed in Table 1-1, with emissions defined in grams per brake-horsepower hour (g/BhpHr). The proposed 2004 and 2007 heavy-duty diesel engine (HDDE) emission standards are identical for the EPA and CARB.

Table 1-1: HDDE On-road Emission Standards (g/Bhp-Hr) [1].

\begin{tabular}{|c|c|c|c|c|c|c|}
\hline \multirow[t]{6}{*}{ EPA\&CARB } & Year & HC & $\mathrm{CO}$ & $\mathbf{N O}_{\mathrm{x}}$ & $\mathbf{P M}$ & \\
\hline & 1988 & 1.3 & 15.5 & 10.7 & 0.6 & \\
\hline & 1990 & 1.3 & 15.5 & 6 & 0.6 & \\
\hline & 1991 & 1.3 & 15.5 & 5 & 0.25 & \\
\hline & 1994 & 1.3 & 15.5 & 5 & 0.1 & \\
\hline & 1998 & 1.3 & 15.5 & 4 & 0.1 & \\
\hline \multirow[t]{4}{*}{ Additional CARB } & Year & NMHC & $\mathrm{CO}$ & $\mathbf{N O}_{\mathrm{x}}$ & $\mathbf{P M}$ & THC \\
\hline & 1987 & - & 15.5 & 6 & 0.6 & 1.3 \\
\hline & 1991 & 1.2 & 15.5 & 5 & 0.25 & 1.3 \\
\hline & 1994 & 1.2 & 15.5 & 5 & 0.1 & 1.3 \\
\hline \multirow[t]{5}{*}{ EPA/CARB } & \multirow[t]{3}{*}{2004} & Option & $\mathbf{N M H C}+\mathrm{NO}_{\mathrm{x}}$ & NMHC & & \\
\hline & & 1 & 2.4 & $\mathrm{n} / \mathrm{a}$ & & \\
\hline & & 2 & 2.5 & 0.5 & & \\
\hline & \multirow[t]{2}{*}{2007} & PM & NOx & NMHC & & \\
\hline & & 0.01 & 0.2 & 0.14 & & \\
\hline
\end{tabular}

The engine certification testing procedure involves exercising an engine on a preset series of speed and torque points selected to represent a typical in-use driving pattern. The heavy-duty Federal Test Procedure (FTP) cycle is the present certification standard in the United States [1]. Since the onset of certification, several other attempts have been made to quantify the average characteristics of in-use operation, and other cycles have been produced and put into practice in 
Europe and the United States.

The complex nature of vehicle operation makes it difficult to reproduce an average cycle, and the cycles are often not representative of real in-use operation. Chassis dynamometer testing more closely involves in-use emissions. Though a more realistic attempt at measuring in-use engine operational emissions, there still exist several fallacies in the method. Vehicle altitude changes, humidity fluctuations, driving style, and vocation are some examples of the nearly infinite number of variables which may affect engine performance and emissions. These factors, along with the difficulties associated with generating a driving cycle representative of real-world use, lead to the need for an on-road testing system.

\subsection{Overview}

The funding and focus of this study comes in part from WVU's contribution to the settling heavy-duty engine manufacturers (S-HDDE) efforts towards satisfying Consent Decrees signed between several governmental agencies and engine manufacturers, with summarized requirements described in the following excerpt [1]:

In October, 1998, a court settlement was reached between the EPA, Department of Justice, California ARB and engine manufacturers (Caterpillar, Cummins, Detroit Diesel, Volvo, Mack Trucks/Renault and Navistar) over the issue of high $\mathrm{NO}_{\mathrm{x}}$ emissions from heavy-duty diesel engines during certain driving modes. Since the early 1990s, the manufacturers used engine control software that caused engines to switch to a more fuel-efficient (but higher $\mathrm{NO}_{\mathrm{x}}$ ) driving mode during steady highway cruising. The EPA considered this engine control strategy an illegal "emission defeat device".

Provisions of the Consent Decree[s] included the following:

- Civil penalties for engine manufacturers and requirements to allocate funds for pollution research

- Upgrading existing engines to lower $\mathrm{NO}_{\mathrm{x}}$ emissions

- Supplemental Emission Test (steady-state) with a limit equal to the FTP standard and NTE limits of $1.25 \times$ FTP (with the exception of Navistar [International])

Meeting the 2004 emission standards by October 2002, 15 months ahead of time.

The civil penalties discussed include allocation of funding for the research of in-use emissions testing. It is apparent future emissions certification procedures may include the implementation of in-use testing apparatus. 


\subsection{Objectives}

The primary objective of this research effort was to assess the repeatability of in-use emissions testing, and the degree to which an on-road cycle could be faithfully simulated on an engine dynamometer. The MEMS system and engine dynamometer test cell were studied for system repeatability. A correlation between MEMS and test cell emissions measurements was performed to quantify the MEMS system accuracy, noting the test cell measurements are accepted as the benchmark for correlation studies and certification tests.

Beyond the system variation and accuracy, it was necessary to perform analysis to determine the effects of fuel properties on diesel engine performance and emissions; specifically the fuels utilized during the MEMS Phase III testing. Also explored were the effects of operating conditions on engine performance and emissions. Intake depression, exhaust backpressure, fuel temperature, intercooler temperature and air inlet temperature were all quantified in terms of their influence on the engine and its emissions. 


\section{Literature Review}

This chapter contains a review of previous and existing in-use emissions measurement systems; with an emphasis placed on compression ignition engines. A more in-depth analysis of some of the systems is available elsewhere $[1,2,3]$. A portion of this review was summarized from the White paper of the Phase I Consent Decrees work [4]. Systems not discussed in these references are covered in detail in this thesis.

\subsection{In-field Testing}

The earliest attempts of field-testing generally were applied in immobile environments such as mines and stationary engines. Most systems focused on inspection and maintenance procedures or experimental research.

\subsubsection{Southwest Research Institute, 1983}

Southwest Research Institute developed a system in 1983 for diesel engine testing in a mine for inspection and maintenance procedures [5]. The system was comprised of laboratory grade analyzers for emissions measurement including $\mathrm{HC}$, carbon monoxide $(\mathrm{CO})$, carbon dioxide $\left(\mathrm{CO}_{2}\right), \mathrm{NO}_{\mathrm{x}}$, and $\mathrm{O}_{2}$. The system included an engine dynamometer and a mini-dilution tunnel for PM examination. The system had a low level of portability.

\subsubsection{Michigan Technical University, 1992}

In 1992 Michigan Technical University developed a method of emissions measurement for underground mining equipment [6]. The system used heated sample lines and a dilute bag sampling system. It also was capable of analyzing PM through a mini-dilution tunnel. The portable gas analyzers were capable of measuring $\mathrm{CO}, \mathrm{CO}_{2}$, and $\mathrm{NO}$ within $10 \%$ of laboratory grade analyzers. The system was large, and not conducive to on-board vehicle measurement.

\subsubsection{University of Minnesota, 1997}

A portable system was designed with the capability of measuring emissions and detecting engine faults for maintenance procedures by the University of Minnesota in 1997 [7]. The Emissions-Assisted Maintenance Procedure (EAMP) had a good level of portability, and loaded engines by stalling torque converters or hydrostatic transmissions. The system utilized an nondispersive infrared (NDIR) analyzer, Fourier transform infrared (FTIR) spectrophotometer, and electrochemical gas sensors. The system had an error on the order of 5\% when compared to 
laboratory grade analyzers.

\subsection{On-Board Testing}

The advent of on-board testing began with a desire to test engine emissions without removing them from service, a costly and time consuming process. Governmental actions, particularly the 1998 Consent Decrees, have led to the development of systems with the intention of monitoring and possibly as a means of future certification. Several systems are now commercially available, and technology continues to achieve significant advances each year.

\subsubsection{Caterpillar, 1982}

An in-use $\mathrm{NO}_{\mathrm{x}}$ emissions testing system was developed by Caterpillar in 1982, consisting of a bag sampling system, able to remove water from the sample [8]. The system was self powered and the size of a small suitcase. It was also easy to operate and highly portable, yielding results within $10 \%$ of laboratory grade equipment.

\subsubsection{Southwest Research Institute, 1992}

Designed to test automatic transmission busses, in 1992 the Southwest Research Institute's emissions unit employed a multiple gas analyzer for $\mathrm{CO}, \mathrm{NO}_{\mathrm{x}}, \mathrm{O}_{2}$, and $\mathrm{CO}_{2}$ integrated emissions measurements [9]. PM was collected through a mini dilution tunnel. The vehicles were tested at idle no-load tests, with loading accomplished by working the engine against the transmission while in a stationary position. The emissions were measured within $5 \%$ of laboratory grade equipment. The tests do not represent normal operating conditions and were integrated bag results, not continuous brake-specific data.

\subsubsection{General Motors, 1993}

Designed for gasoline passenger vehicles, in 1993 General Motors produced a 400lbs system consisting of two $\mathrm{CO}$ and two $\mathrm{HC}$ analyzers, as well as instruments for $\mathrm{NO}$ and $\mathrm{CO}_{2}$ measurement [10]. Redundant analyzers were used to cover several levels of concentration. The system inferred exhaust flowrate through the vehicle's mass airflow sensor. A slow sample rate of $1 \mathrm{~Hz}$ was unable to accurately capture transient measurements. Power for the system was provided by batteries stored in the trunk of the vehicle.

\subsubsection{Ford Motor Company, 1994}

A mobile emissions measurement system was developed by Ford Motor Company in 1994 to test gasoline vehicle in-use emissions [11-14]. An FTIR was combined with a dilution 
tunnel on an Aerostar van, and compared to laboratory grade analyzers on a chassis dynamometer. The results yielded a difference of $2 \%$ for $\mathrm{CO}_{2}, 3 \%$ for $\mathrm{CO}, 10 \%$ for $\mathrm{NO}_{\mathrm{x}}$, and $7 \%$ for HC. The response of the FTIR system was slow and did not accurately capture transient activity.

Infrared analyzers were fitted to a Ford Taurus, monitoring $\mathrm{CO}, \mathrm{HC}, \mathrm{O}_{2}$, and $\mathrm{CO}_{2}$, and a fast response non-dispersive ultraviolet (NDUV) for CO measurement. A correlation of 0.97 and a slope of 0.8 was the resultant of a comparison between conventional chemiluminescent (CLA) methods and the NDUV device.

\subsubsection{U.S. Coast Guard, 1997}

On-board testing of U.S Coast Guard Cutters in 1997 achieved brake-specific mass emissions measurements of $\mathrm{CO}, \mathrm{NO}, \mathrm{NO}_{2}$, sulfur dioxide $\left(\mathrm{SO}_{2}\right), \mathrm{O}_{2}$, and $\mathrm{HC}[15,16]$. A multiple gas analyzer was used to perform the analysis, and $\mathrm{CO}_{2}$ was inferred through the measured emission levels. Air and fuel measurements were recorded, and strain gauges on the output shafts of the motor allowed measurement of torque. The system was bulky but effective in measuring in-use brake-specific emissions.

\subsubsection{University of Pittsburgh, 1997}

A vehicle emissions analyzer was designed for inspection and maintenance of a fleet of compressed natural gas (CNG) vans in 1997 at the University of Pittsburgh [17]. A multiple gas analyzer measured raw gas concentrations of $\mathrm{HC}, \mathrm{CO}, \mathrm{CO}_{2}, \mathrm{NO}$, and $\mathrm{O}_{2}$. Engine data was broadcasted via an on-board diagnostic (OBD) II adaptor, and recorded by third party diagnostic equipment. The $\mathrm{HC}$ results were biased because the emissions equipment was designed for measuring gasoline engine emissions. Issues arose concerning mass emission rates, time alignment of data, and analyzer response times. The system had a fair level of portability.

\subsubsection{The Flemish Institute for Technological Research (VITO), 1997}

Vito's On-the-road Emission and Energy Measurement (VOEM) was developed to report distance specific gaseous emissions. NDIR analyzers were used to measure $\mathrm{CO}_{2}$, with a flame ionization detector (FID) measuring $\mathrm{HC}$ concentrations, a CLA to measure $\mathrm{NO}_{\mathrm{x}}$. A heated sample line prevented loss of heavy hydrocarbons, drawing exhaust from an nitrogen driven ejector. Fuel consumption, engine speed, and a derivation of exhaust flow from a lambda value were used for calculation of distance and time specific emissions. The unit was heavy at $500 \mathrm{lbs}$, and was battery powered with an operation time of one hour [18]. 


\subsubsection{Northeast States for Coordinated Air Use Management (NESCAUM), 1998}

Focused on the in-use emissions of off-road diesel vehicles, in 1998 NESCAUM studied emissions with a mini dilution tunnel and a five gas analyzer, as well as a bag sampling system [19]. The exhaust sample was fed to the dilution tunnel through heated lines. PM was collected with $70 \mathrm{~mm}$ filters. The gaseous emissions measured included $\mathrm{NO}_{\mathrm{x}}, \mathrm{CO}$, total hydrocarbons (THC), and $\mathrm{CO}_{2}$. Fuel rate was inferred from $\mathrm{CO}_{2}$ levels. The system was unreliable and inaccurate, with $27 \%$ difference from laboratory grade analyzers for CO, $12 \%$ difference for $\mathrm{NO}_{\mathrm{x}}$, and $22 \%$ difference for $\mathrm{HC}$.

\subsubsection{Office of Mobile Sources: US-EPA, 1999}

The EPA Office of Mobile Sources developed a light-duty gasoline emissions measurement system, named Real-time On-road Vehicle Emissions Reporter (ROVER) [4]. The ROVER system measured exhaust flowrate with an Annubar flow meter, and uses a multi-gas analyzer for gaseous emissions of $\mathrm{CO}, \mathrm{CO}_{2}, \mathrm{HC}, \mathrm{O}_{2}$, and $\mathrm{NO}$. Engine speed and air-to-fuel ratio $(\mathrm{A} / \mathrm{F})$, and fueling rate were measured for implementation in emission rate calculations.

The ROVER system did not implement a heated sample line or filter, necessary to avoid water and $\mathrm{HC}$ condensation. The ROVER did not contain catalyst for conversion of $\mathrm{NO}_{2}$ to $\mathrm{NO}$. The relationship between $\mathrm{NO}$ and $\mathrm{NO}_{2}$ was not easily predicted, and without a converter catalyst $\mathrm{NO}_{\mathrm{x}}$ could not be correctly reported. Another point of concern in the ROVER design was the alteration of exhaust flow when the sampling system was added. The natural flow and pressure of the exhaust was modified for each vehicle and does not reproduce normal operating conditions. The impact of such restrictive alterations is discussed in section 6.4.3.

\subsubsection{Ford Motor Company and WPI-Microprocessor Systems, Inc., 1999}

A Portable Real-Time Emission Vehicular Integrated Engineering Workstation (PREVIEW) was developed by Ford Motor Company in 1999 to measure mass concentrations of $\mathrm{CO}, \mathrm{CO}_{2}, \mathrm{NO}$, and $\mathrm{HC}$ for gasoline-fueled vehicles [20]. The system was able to measure engine parameters through the electronic control unit (ECU) readout. The system was compared to a chassis dynamometer and yielded measurement differences of $1.5 \%$ for $\mathrm{CO}_{2}, 3.4 \%$ for $\mathrm{CO}$, $12.3 \%$ for $\mathrm{HC}$, and $0.4 \%$ for $\mathrm{NO}$.

\subsubsection{Horiba, Ltd. and NGK Insulators, 2000}

An on-board measurement system was designed to evaluate $\mathrm{NO}_{\mathrm{x}}$ emissions of diesel vehicles by Horiba, Ltd. and NGK Insulators in 2000 [21]. The system used a zirconium oxide 
$\left(\mathrm{ZrO}_{2}\right)$ sensor to measure $\mathrm{NO}_{\mathrm{x}}$ in a $0-1000 \mathrm{ppm}$ range. The system had the capability of measuring air flow rate with a Karman vortex volumetric flow meter. It was also capable of measuring intake air pressure, intake air temperature, intake air relative humidity, boost pressure, vehicle speed, engine speed, coolant temperature, and ambient pressure and temperature. It was small enough to sit on the passenger seat of a vehicle and required no external power. A relationship to laboratory grade analyzers was found to be $4 \%$ for $\mathrm{NO}_{\mathrm{x}}$ and $3 \%$ fuel recovery measurements and $1 \%$ for distance measurements.

\subsubsection{University of California, Riverside, and Honda R\&D, 2000}

A study was performed by the University of California, Riverside to validate the portable low-emission in-use measurement system created by Honda [22]. The system was found to accurately measure the in-use emissions of ultra-low emission vehicle(s) (ULEV), and was able to measure ambient roadway concentrations of $\mathrm{MNHC}, \mathrm{CO}$, and $\mathrm{NO}$.

\subsubsection{EPA - On-Road Diesel Emissions Characterization (ODEC), 2002}

The EPA Office of Research and Development researched the characteristics of heavyduty diesel exhaust stack and emissions and plume development $[23,24]$. The ODEC facility consisted of a trailer with laboratory grade emissions analyzers and an "ejector dilutor" dilution air system. The analyzers were a Tapered Element Oscillating Microbalance (TEOM) capable of PM measurement, a Polycyclic Aromatic Hydrocarbon (PAH) analyzer detecting aromatic hydrocarbons on a photoelectric ionization principle, and a Condensation Nucleus Counter (CNC), which detected 1 to 3 micron particles, for particulate counting or sizing.

The system was capable of results in a mass or energy specific basis, and made novel strides to quantify in-use exhaust plume characteristics. Some difficulties arose during testing, with unrealistic PM emissions and difficulties in understanding the dilution requirements for plume sampling. Since publication of the referenced sources, the authors replaced several analyzers, and redesigned the system to refine their plume measurement process.

\subsubsection{Honda R\&D Americas, Inc., 2000}

Honda, in cooperation with Nicolet Instrumentation Corporation, designed an FTIR system for measuring emissions from advanced low emission vehicles [25]. The on-board system was capable of measuring gasoline vehicle emissions at ULEV levels and below. System correlation was performed with gas bottles of known concentrations and laboratory grade analyzers, yielding measurement results within 5\%. Measured emissions were non-methane 
hydrocarbons (NMHC), $\mathrm{NO}_{\mathrm{x}}$, and $\mathrm{CO}$.

\subsubsection{Technical Research Center of Finland (VTT Energy), 2001}

In 2001 transit busses powered by a variety of fuels were tested by VTT Energy using an on-road emissions measurement system [26]. An NDIR 4-gas analyzer of repair shop quality measured $\mathrm{HC}$ (poor accuracy), $\mathrm{CO}( \pm 0.005 \%), \mathrm{CO}_{2}( \pm 0.2 \%)$, and $\mathrm{O}_{2}( \pm 0.4 \%)$. Accuracy reported was from manufacturer's specifications. An Echophysics CLD $700 \mathrm{RE} \mathrm{NO}_{\mathrm{x}}$ analyzer yielded $5 \mathrm{~Hz}$ measurements. The $\mathrm{NO}_{\mathrm{x}}$ analyzer measured a range of 0 to $2500 \mathrm{ppm}$ with a reported accuracy of $2 \%$.

The exhaust flowrate was measured using a hot film Sensyflow VT2 flow meter. The manufacturer's reported accuracy of the hot film was $\pm 1 \%$, and required 6.5 feet of straight exhaust section prior to measurement. The speedometer signal was used to measure vehicle

speed, which was unreliable and inaccurate. A gasoline generator was used to power the system, which did not provide a dependable power supply. Installation of the emissions measurement and data acquisition system was difficult and time consuming.

Fuel consumption was calculated by weighing the fuel before and after the tests for the diesel engines, and for gaseous fuel engines consumption was also derived from $\mathrm{CO}_{2}$ emission values. A correlation of the system to laboratory grade analyzers was not completed.

\subsubsection{Clean Air Technologies International, 2001}

A real-time in-use $\mathrm{NO}_{\mathrm{x}}, \mathrm{CO}, \mathrm{CO}_{2}$, and $\mathrm{PM}$ system was developed by Clean Air Technologies in 2001 [27]. An NDIR analyzer was used to measure $\mathrm{CO}$ and $\mathrm{CO}_{2}$ emissions. $\mathrm{NO}_{\mathrm{x}}$ was estimated from $\mathrm{NO}$ emission levels obtained from an electrochemical (EC) cell. PM was measured using a photo detector and two laser beams. Exhaust flow was inferred using engine intake and fueling information obtained from the diagnostic port. If the vehicle was incapable of reporting engine information and intake mass air flow, temporary sensors were installed on the engine to obtain these values.

Unheated, raw exhaust was sampled directly from the tailpipe using a 1/4 inch diameter sample line. The water in the exhaust was condensed in a separation bowl. Difficulty arose in measuring the engine characteristics from the OBD port, invalidating a large portion of the tests. Error was also generated in misaligned flow data. Significant noise was experienced in the data acquisition system. Poor quality control nullified a portion of the tests, as well as incorrect calibration gas concentrations. 
The relationship between $\mathrm{NO}$ and $\mathrm{NO}_{2}$ was not easily predicted, and the condensation of water in exhaust and the cooling of exhaust gas may have altered the concentrations of $\mathrm{NO}$ and $\mathrm{NO}_{2}$. These factors, in conjunction with the unreliability and slow time response of the EC cells used, generated error in measurement of $\mathrm{NO}_{\mathrm{x}}$. $\mathrm{CO}$ and $\mathrm{NO}_{\mathrm{x}}$ were not correlated to research grade analyzers on a percentage basis, but the trends of emissions measured by the mobile system were comparable to those seen in the laboratory grade analyzers. PM data was not correlated with standard measurement methods, and the validity of measurements was inconclusive. Flowrate measurement errors presented up to $25 \%$ discrepancy with laboratory data.

The system was small and unobtrusive, and easily installed on vehicles with OBD ports. The system drew power from the vehicle at a potential (V) of 12 Volts and a current (I) of 15 Amperes. No analysis was performed on the effects of emission parasitic losses as a result of the load on the engine seen from powering the system from the vehicle's battery, but assuming an maximum efficiency of $50 \%$ in the alternator ( $\left.\eta_{\text {alternator }}\right)$ and $95 \%$ efficiency in the belt system $\left(\eta_{\text {belt }}\right)$ [28], the load on the engine was $1 / 2 \mathrm{hp}$, calculated in Equation 1.

$$
\text { Power Consumed }=V * I * \frac{1 H p}{745.7 \text { Watt }} * \eta_{\text {alternator }} * \eta_{\text {belt }}
$$

Equation 1

\subsubsection{Analytical Engineering, Inc. (AEI), 2001}

AEI designed an emissions measurement system in 2001, the Simple Portable On-vehicle Testing (SPOT) [29]. Partially funded by the EPA, SPOT was designed to measure $\mathrm{NO}_{\mathrm{x}}$ and $\mathrm{O}_{2}$. $\mathrm{CO}_{2}$ was calculated from the obtained value of $\mathrm{O}_{2}$. Exhaust mass flow was calculated, and measured ambient conditions included relative humidity and ambient temperature, as well as a variety of ECU broadcast engine conditions. The emissions were reported in estimated brakespecific mass and distance-specific mass values. Location was recorded via global positioning sensor (GPS), and the unit was monitored remotely through a cellular data link. The system was small and portable, and the wireless transmission of data to the acquisition system removed the hazard of vehicle vibration and extreme ambient conditions, as well as reducing the amount of on-board equipment necessary. 
SPOT was upgraded following the initial design phase. To measure exhaust flow rate a converging nozzle was placed in the center of the flow. The nozzle caused the fluid velocity to increase, decreasing the pressure. The pressure drop created a vacuum which drew air from a meter, the metered air measurement being a linear relation to the velocity of the fluid. $\mathrm{A} \mathrm{ZrO}_{2}$ sensor was placed next to the nozzle to measure the $\mathrm{NO}_{\mathrm{x}}$ levels in the raw exhaust. Testing was not yet completed for validation of the system accuracy.

\subsubsection{Engine, Fuel, and Emissions Engineering, Inc., 2001}

The Ride Along Vehicle Emissions Measurement System (RAVEM) was a constant volume sampling (CVS) system designed in 2001 by the Engine, Fuel, and Emissions

Engineering, Inc. to test in-use diesel, gasoline, and alternative fuel vehicles [30]. Measurements of $\mathrm{CO}$ and $\mathrm{CO}_{2}$ concentrations were performed with an California Analytical Instruments (CAI) ZRH-2 NDIR analyzer, and $\mathrm{NO}_{\mathrm{x}}$ was measured with an CAI 400S-HCLD heated chemiluminescent analyzer. PM was measured through a sample line from the primary dilution tunnel and deposited on a $37 \mathrm{~mm}$ Teflon-coated borosilicate glass fiber. Dilution air entered the tunnel following a High Efficiency Particulate Arresting (HEPA) filtration system, and was evacuated by means of a CVS pump. Work for the brake-specific emissions calculations were inferred from the CARB estimate of $18.5 \mathrm{Bhp}-\mathrm{Hr}$ /gallon of diesel fuel for modern diesel engines. It is noted the average for tests performed for this thesis was approximately $2.4 \mathrm{Bhp}$ $\mathrm{Hr} /$ gallon. A valid correlation of data to proven analysis methods was not reported, however the brake-specific levels of gaseous emissions were significantly higher than vehicle certification levels. It is also noted the sampling probe for the extraction of exhaust stack emissions was a single inlet probe facing upstream flow, which did not yield a true representation of developed exhaust flowrate conditions. The system was portable but bulky, and was not designed to perform in inclement weather.

Improvements were made to the system for in-use ferry boat testing performed in California [31]. Concentrations of NO were measured on an integrated basis by bypassing the $\mathrm{NO}_{2}$ to $\mathrm{NO}$ converter on the chemiluminescent analyzer. Methane and total NMHC were measured by off-board gas chromatographic analyzers and FID technology, drawing samples from Tedlar bag samples taken during in-use testing. Speciated NMHC were analyzed by an offboard gas chromatographic / mass spectrometer analyzer. Speciated carbonyls were collected by injection integrated samples into di-nitro phenyl hydrazine cartridges, analyzed off-board by high 
performance liquid chromatography. Integrated $\mathrm{SO}_{2}$ was measured by FTIR spectroscopy, and integrated $\mathrm{NO}_{2}$ and $\mathrm{NH}_{3}$ concentrations were measured by FTIR analyzers.

\subsubsection{Sensors, Inc., 2002}

Sensors developed a system in 2002 capable of testing in-use diesel emissions [32,33].

Dubbed SEMTECH-D, the system used SAE J1587 or J1939 ECU interface protocols to calculate emissions on a g/Bhp-Hr and g/mile basis. A FID was used for THC analysis. CO and $\mathrm{CO}_{2}$ were measured with an NDIR analyzer, and $\mathrm{NO}_{\mathrm{x}}$ was measured using a proprietary garagegrade NDUV analyzer. Data was sampled at a speed of $1 \mathrm{~Hz}$. Accuracy, range, and resolution of the system is reported in Table $2-1$.

Table 2-1: SEMTECH-D Product Specifications

\begin{tabular}{|l|l|l|l|}
\hline & Range & Resolution & Accuracy \\
\hline $\mathrm{CO}_{2}$ & $0-20 \%$ & $0.10 \%$ & $200 \mathrm{ppm}$ or $\pm 3 \%$ of $\mathrm{rdg}$ \\
\hline $\mathrm{CO}$ & $0-5000 \mathrm{ppm}$ & $1 \mathrm{ppm}$ & $\pm 50 \mathrm{ppm}$ or $\pm 3 \%$ of $\mathrm{rdg}$ \\
\hline & $0-8 \%$ & $0.001 \%$ & $\pm 0.02 \%$ or $\pm 3 \%$ of $\mathrm{rdg}$ \\
\hline $\mathrm{THC}$ & $0-1000 \mathrm{ppm}$ & $0.1 \mathrm{ppm}$ & $5 \mathrm{ppm}$ or $\pm 1 \%$ of $\mathrm{rdg}$ \\
\hline & $0-10000 \mathrm{ppm}$ & $1 \mathrm{ppm}$ & $\pm 25 \mathrm{ppm}$ or $\pm 1 \%$ of rdg \\
\hline $\mathrm{NO}$ & $0-5000 \mathrm{ppm}$ & $1 \mathrm{ppm}$ & $\pm 15 \mathrm{ppm}$ or $\pm 3 \%$ of rdg \\
\hline $\mathrm{NO}_{2}$ & $0-500 \mathrm{ppm}$ & $1 \mathrm{ppm}$ & $\pm 10 \mathrm{ppm}$ or $\pm 3 \%$ of rdg \\
\hline
\end{tabular}

\subsubsection{University of Alberta, 2003}

Distance specific $\mathrm{HC}, \mathrm{CO}, \mathrm{CO}_{2}$, and $\mathrm{NO}_{\mathrm{x}}$ mass emissions were measured by the University of Alberta in 2003 for a study on the effects of ambient conditions on emissions factors [34]. A five gas Vetronix PXA -1100 analyzer drew a sample from the tailpipe outlet. The system was based on NDIR technology.

Intake flow rate was measured using a hot wire mass air flow sensor, and instantaneous fuel rate was inferred from a fast response lambda sensor. Other parameters measured included coolant temperature, intake air temperature, ambient air temperature, vehicle and engine speed. Barometric pressure was measured with a barometer following each test sequence.

Some sources of error were found in the equipment and methods described. Alberta reported calibration inaccuracies of 2.1 and $4.9 \%$ for $\mathrm{CO}$ and $\mathrm{NO}_{\mathrm{x}}$, and NDIR methods were known to be inaccurate for measurement of hydrocarbons other than n-alkanes. The sample line 
was insulated, but unheated. If an exhaust sample dropped below the dew point, there may have been condensation of heavy hydrocarbons, and other chemical reactions may have occurred to alter the emissions concentrations once they reached the analyzers. Insulation alone did not insure the sample maintained a condition above the dew point; consequently errors in data may have been present. Brake-specific mass emissions were not reported, and testing was performed only on gasoline powered vehicles.

\subsection{Previous Assessments of the Impact of Fuel and Operating Conditions on Emissions and Engine Performance}

Attempts have been made to examine the effects of operating conditions and fuel characteristics on engine performance, gaseous emissions and particulate emissions. Most studies on operating conditions were based on coolant temperature control.

Many studies focused on the effect of diesel fuel properties on engine emission and performance. Most studies found it difficult to accurately predict the response of emissions and performance due to changes in fuel properties without direct control of injection timing, boost pressure, and air temperature [35]. Some general trends, however, were noticed. A 1975 study performed by Cummins Engine Co. concluded decreasing $\mathrm{CO}$ and $\mathrm{NO}_{\mathrm{x}}$ emissions occurred with increases in cetane number [36]. American Petroleum Institute (API) gravity of the fuel was also analyzed, with little correlation drawn to emission impact. It was noted an increase in API gravity resulted in a reduction of brake specific fuel consumption (BSFC), yet an increase in volumetric fuel consumption (gal/Bhp-Hr). Increases in ambient temperature were found to decrease starting time of the engine.

Navistar completed a study in 1988 relating the effects of sulfur content on diesel emissions [37]. The study found similar trends for direct and indirect injection engines, with and without turbocharger apparatus. The sulfur content was varied from 0.05 to $0.29 \%$ by weight, and an increase in sulfur content increased the brake-specific PM emission from 0.06 to 0.07 $\mathrm{g} / \mathrm{Bhp}-\mathrm{Hr}$. Increases in fuel sulfur content also increased the percent sulfate in TPM.

Southwest Research Institute performed an extensive analysis of cetane number and aromatic content on diesel engine emissions [38]. It was determined cetane number increases reduced $\mathrm{HC}$ emissions, and $\mathrm{HC}$ was unrelated to aromatic content. Emissions of $\mathrm{CO}$ concentrations were found to reduce with cetane number increases, and $\mathrm{CO}$ emissions were 
found to have no relation to aromatics. Reductions of $\mathrm{NO}_{\mathrm{x}}$ emission was apparent with increases of cetane and decreases of aromatic content. All relationships decreased in significance when high values of cetane number were approached.

A 1992 study performed by Nissan Diesel Motor Co., Ltd discovered enriching aromatic content in diesel led to an increase in $\mathrm{NO}_{\mathrm{x}}, \mathrm{CO}$, and $\mathrm{THC}$ emissions [39]. It was also found that an increase in aromatic content increased the PM production. It was concluded that the optimal fuels for emission reduction were low sulfur and low aromatic content fuels.

PM-fuel relations were analyzed by Shell Research Ltd in 1994 [40]. It was reported an increase in density and aromatic content increased brake-specific PM, and increasing cetane number generally decreased PM emission. Lowering the sulfur content of fuel from $0.037 \%$ weight to $0.023 \%$ weight reduced PM emission up to $12 \%$, decreasing density reduced PM by $13 \%$, and cetane increases reduced PM emission by $5 \%$ in a Euro- 1 cycle.

Texaco, Inc. performed a study regarding the effects of diesel fuel on emissions [41]. It was concluded fuels with higher cetane number generated lower $\mathrm{NO}_{\mathrm{x}}$ emission levels than lower cetane number fuels when aromatic content was held constant. It was also noted there was little or no $\mathrm{NO}_{\mathrm{x}}$ reduction when high cetane number fuels had their cetane numbers increased naturally or through additives. $\mathrm{HC}$ emissions were found to be unrelated to cetane number. PM emissions were not affected by cetane number fluctuations when under light and medium load, but under high load the PM emissions of higher cetane number fuels were greater than that of low cetane number fuels.

Shell oil conducted a 1996 study on a low $\mathrm{NO}_{\mathrm{x}}$ fuel [42]. A variance analysis found fuel had significant impact on $\mathrm{HC}, \mathrm{NO}_{\mathrm{x}}$, and $\mathrm{PM}$ emissions of a heavy-duty diesel. The low $\mathrm{NO}_{\mathrm{x}}$ fuel was found to reduce brake-specific $\mathrm{NO}_{\mathrm{x}}$ and $\mathrm{PM}$ emission by as much as $14 \%$, and $\mathrm{HC}$ emission by $6 \%$.

An analysis of synthetic fuel blending was performed in a section of a 1997 paper presented by Sasol Oil [43]. A Sasol fuel blend was found to have $49 \% \mathrm{HC}$ emission reduction, $33 \% \mathrm{CO}$ reduction, $27 \% \mathrm{NO}_{\mathrm{x}}$ reduction, and $21 \% \mathrm{PM}$ reduction over conventional 2-D rated diesel fuel. CARB fuel was also found to lower $\mathrm{HC}, \mathrm{CO}$, and $\mathrm{NO}_{\mathrm{x}}$ when compared to 2-D fuels.

WVU performed extensive studies relating to alternative fuels and their impact on engine emissions [44,45]. Fuels included low sulfur pump diesel, California pump diesel, Malaysian Fischer-Tropsch fuel, soy fuels and bio-diesels. Emission reductions were as high as $60 \%$ for 
$\mathrm{HC}$. $\mathrm{NO}_{\mathrm{x}}$ was reduced in some instances by over $25 \%$ from low sulfur pump fuel, and increases from low sulfur were as high as 11\%. A Fischer-Tropsch fueled emission analysis found CO was reduced up to $46 \%$, and PM as much as $42 \%$.

In 2000 the University of Tokushima conducted research on the effects of fuel properties on direct-injection diesel engines [44]. Cetane number and aromatic content were varied independently. It was shown for fuels of like aromatic content, decreasing the cetane number increased ignition delay, decreasing $\mathrm{PM}$ and increasing $\mathrm{NO}_{\mathrm{x}}$ emission. High cetane number fuels were found to increase PM due to an increase in combustion duration. Aromatic content had little effect on combustion quality, but high aromatic content increased both $\mathrm{NO}_{\mathrm{x}}$ and $\mathrm{PM}$ emissions. It was also concluded a raise in injection pressure made the effects of cetane number and aromatic content less significant.

A 2003 study performed by the Japan Automobile Research Institute tested 9 fuels, focusing on density and viscosity correlations [46]. The engine of focus was a common rail direct injection diesel, turbocharged and after-cooled. It was found that an increase in density increased brake-specific PM, and decreased brake specific $\mathrm{NO}_{\mathrm{x}}$. An increase in density was also found to lower CO and THC emissions. Little conclusion was drawn on the effects of viscosity, other than an increase lead to an increase in Sauter mean diameter of the fuel spray, increasing PM.

It should be noted the combustion events in modern electronically controlled diesel engines are not only influenced by temperatures, pressures, heat transfer, etc. (as in mechanically controlled engines) but also by the injection control strategy (start of injection, injection duration, rate shaping, etc.). It can be difficult to differentiate differences in engine performance and emissions without proper diagnostic tools or knowledge of the control strategy. Though some studies reviewed had access to injection control strategy data, the experiments conducted for this research were performed without knowledge of these strategies. 


\section{Experimental Procedures and Equipment}

Engine dynamometer and laboratory equipment calibration at the WVU Engine and Emissions Research Center (EERC) were performed in accordance to the standards set by the Code of Federal Regulations (CFR) 40, Part 86 [47]. MEMS system calibration was performed in accordance to the requirements specified in Phase II of the Consent Decree Testing [48]. Both the EPA and the S-HDDE approved MEMS equipment and testing procedures. Tests that contained gross error(s) on account of known system failures were removed from the test sample to insure unbiased results. Errors in data may include faulty RTD temperature sensors, incorrect laboratory valve settings, or other mechanical or operator errors. Continuous data was analyzed to determine sources of error. Data containing significant variation in comparison to similar cycles was closely scrutinized, and if no mechanical or operational errors were discovered, the data remained in the test set. Accuracies of system components of interest for the EERC and MEMS are available in Appendix A.

\subsection{Vehicles Tested}

Thirty-six vehicles were tested in field during Phase III of the program. Vehicles ranged in model year from 1994 to 2001. All were electronically controlled and turbocharged, and none had EGR or aftertreatment technology. Engines ranged in displacement from 7.3 to 14.6 liters, and vehicle weight ranged from 15,000 to 80,000 GVWR. Each vehicle traveled through predefined routes consisting of highway and urban driving [48]. The six settling engine manufacturers affected by the Consent Decrees were required to validate on road data by correlating MEMS units to laboratory grade analyzers on an engine dynamometer. One engine from each manufacturer was installed on the WVU EERC engine dynamometer for such purposes. Due to the sensitivity of the data from these studies, individual results, vehicle, and engine specifications were not presented.

\subsection{Engine and Emissions Research Laboratory}

The WVU EERC was capable of conducting emissions research for medium and heavyduty engines. The EERC employed several eddy current dynamometers, water dynamometers, an AC and a DC dynamometer. The laboratory was constructed in 1993, in accordance to the 
specifications of the CFR 40, Part 86, Subpart N, and was maintained and tested in compliance with these specifications [47]. The components of the test cell and dynamometer equipment employed for data related to this study are described in the following sections, and a schematic is available in Appendix B.

\subsubsection{Full Flow Exhaust Dilution Tunnel}

The dilution tunnel was an 18 inch diameter stainless steel duct, 40 feet in length. A 75 hp blower pulled temperature controlled dilution air through a combination of up to four venturis for a nominal flow rate range of 400 to $3400 \mathrm{cfm}$. A five inch pipe directed exhaust midstream of the tunnel entrance. Three feet past the entrance of the tunnel, an orifice was placed in the tunnel to aide in mixing of the exhaust gas with the dilution air. Sample probes for analyzers were located 15 feet downstream of the exhaust inlet.

\subsubsection{Engine Dynamometer}

A General Electric DYC-243 DC dynamometer was used to apply loading to the engines. The dynamometer was capable of absorbing a maximum of $550 \mathrm{hp}$, and $500 \mathrm{hp}$ while motoring. The torque output was measured via a load cell attached to the stator. The dynamometer speed was digitally reported by the dynamometer control system. The engine was coupled to the dynamometer shaft via a driveshaft system.

\subsubsection{Critical Flow Venturi}

A CVS system, as described in the CFR 40, Part 86, Subpart N [47], is governed by critical flow venturi. The laboratory implements three venturis rated at nominal flow of 1000 $\mathrm{cfm}$ and one venturi rated at a nominal flow of $400 \mathrm{cfm}$. The venturis volumetric flow rate is given in Equation 2 and is described in terms of absolute pressure and absolute temperature at the venturi:

$$
\dot{Q}=K_{V} \frac{P}{\sqrt{T}},
$$

Equation 2

Where $\dot{Q}$ is the mass flow rate in scfm, $\mathrm{K}_{\mathrm{V}}$ is the calibration coefficient, $\mathrm{P}$ is the absolute pressure at the throat of the venturi, and $\mathrm{T}$ is the absolute temperature at the inlet. This equation was intended for choked sonic flow, with a calculated constant $\mathrm{K}_{\mathrm{V}}$. In some instances (a relatively high tunnel temperature), the $3400 \mathrm{scfm}$ tunnel was not be capable of maintaining sonic flow at the throat of the venturi and was not used. 


\subsubsection{Zero Air Generator}

Zero air was generated in-house, feeding the CLA NO analyzer, zero air for the FID HC analyzer, as well as zero air for other applications. A Balston 75-52 purge gas generator supplied purge air to a Balston 75-87 zero air generator. The zero air was stored in a Balston 72-012 pressure vessel. The zero air was drawn through a Balston A963-107 filter element to insure air cleanliness. Manufacturer air quality claimed $<1 \mathrm{ppm}$ THC.

\subsubsection{Gaseous Emission Analyzers}

Laboratory grade analyzers were used for all gaseous emissions and background air measurement. The analytical bench at WVU as comprised of heated sample probes and lines, heated pumps and filters, and a chiller for condensing water to protect $\mathrm{CO}$ and $\mathrm{CO}_{2}$ analyzers. The dilute exhaust mixture was maintained at temperatures greater than the mixture dew point.

Although the dew point of the mixture was relatively low (approximately $120^{\circ} \mathrm{F}$ ), the CFR 40, Part 86 requires the primary sampling lines for non-methanol fuels be maintained at 235 $\pm 15^{\circ} \mathrm{F}$, sample lines for heated flame ionization detector (HFID) analyzers be maintained at 375 $\pm 20^{\circ} \mathrm{F}, \mathrm{NO}_{\mathrm{x}}$ analyzers be maintained greater than $140^{\circ} \mathrm{F}$ and less than $446^{\circ} \mathrm{F}$, and the $\mathrm{CO}$ and $\mathrm{CO}_{2}$ analyzers were maintained at $235 \pm 15^{\circ} \mathrm{F}$ prior to the chiller unit [47]. The temperatures for the analyzers were significantly higher than the dew point, especially in the instance of the HC analyzer. The increased temperature for $\mathrm{HC}$ analysis also insures the heavy hydrocarbons do not condense in the sample line.

\subsubsection{HC Analyzer}

A Rosemont Analytical Model 402 analyzer implemented HFID technology for measuring $\mathrm{HC}$ concentrations. A flame, fueled by a combination of $40 \%$ helium and $60 \%$ hydrogen, burned elemental hydrogen-carbon molecules in the sample, forming positively charged ions and electrons. The ions and electrons were attracted to a respective cathode and anode. A small current was created which was proportional to the amount of carbon atoms in the sample gas. An amplified analog voltage was output proportional to the current generated by this process.

\subsubsection{NO $_{\mathrm{x}}$ Analyzer}

A Rosemount Analytical Model 955 CLA detected concentrations of NO. For measurement of $\mathrm{NO}_{\mathrm{x}}, \mathrm{NO}_{2}$ was converted in an internal catalyst to form $\mathrm{NO}$. This process occurred in a heated environment inside the analyzer. The NO was reacted to form ozone, 
emitting an ultraviolet radiation in a quartz tube. A photo-multiplier tube enhanced the light intensity, which a photo-detector converted into a voltage proportional to the number of NO molecules in the sample. An analog 0-5 V signal was output representing a zero to full-scale calibration gas concentration.

\subsubsection{3 $\mathrm{CO}_{2}$ Analyzer}

A Horiba AIA-210 NDIR analyzer was used to report $\mathrm{CO}_{2}$ concentrations. NDIR instruments use the principle of light spectrum absorption characteristics of a gas. Two cells, one containing sample gas and another containing a reference gas with differing and preset light absorption properties (commonly nitrogen), were inundated with light. The light output was measured for each cell, and the ratio of the absorption yielded a concentration value of $\mathrm{CO}_{2}$.

\subsubsection{Carbon Monoxide (CO) Analyzer}

A HORIBA AIA-210LE NDIR analyzer was used to measure CO concentrations. The principles governing measurement were identical to that of the $\mathrm{CO}_{2}$ analyzer, with the exception of the light bands corresponding to $\mathrm{CO}$ are measured.

\subsubsection{PM Sampling}

A proportional sampling system diluted exhaust through a filter housing containing a primary and a secondary T60A20 70mm Pallflex fluorocarbon coated glass filter. The sample was drawn from the same location in the dilution tunnel as the gaseous emissions lines. The maximum filter face temperature was maintained below $125^{\circ} \mathrm{F}$ during testing per the requirements of the CFR 40, Part 86 [47]. Filters were preconditioned for a minimum of six hour in a temperature and humidity controlled environment with a target temperature of $71.6 \pm 5$ ${ }^{\circ} \mathrm{F}$, and relative humidity of $45 \pm 8 \%$.

A Cahn model C-32 microbalance with a resolution of $1 \mu \mathrm{g}$ was used for filter weighing. Prior to each weighing session, a calibration was performed and reference filters were weighed. Two reference filters were changed at least once per month, each with a maximum weight change of 40 micrograms.

Following each test, the filters were conditioned to chamber conditions. Background PM data was collected at the conclusion of each day testing occurred, and background PM weight was subtracted from the total PM weight for each cycle.

For steady state cycles, a solenoid controlled bypass system was employed to maintain a constant sample flow through the secondary dilution tunnel for the duration of the test. During 
the stabilization phase, a large replaceable fibrous filter was used to collect PM. During the collection phase, PALL in-line T60A20 Pallflex 70mm filters collected PM for analysis.

\subsubsection{Bag Sampling}

Exhaust and background gasses were collected in separate 80 liter Tedlar bags for integrated emissions analysis. The dilute samples were drawn at the same location in the tunnel as the continuous emissions sample probes, through the ambient temperature Teflon tubing. The background bag emissions were drawn through ambient temperature Teflon tubing from the dilution air prior to the introduction of exhaust in the dilution tunnel. The background emissions were subtracted from total emissions measured to yield engine out emission levels. The dilute sample was used as a comparison with integrated continuous sampling for Quality Assurance/ Quality Control (QA/QC).

\subsubsection{Fuel and Air Flow Measurement}

Fuel flow rate was measured using a MAX Machinery 710 portable fuel flow measurement system. A pressure regulated pump and water-to-fuel heat exchangers supplied fuel through a rotary vane measurement device. Included in the MAX 710 measurement system was a 284-512 flow transmitter, which converted the rotary motion of the fuel meter to a 5V TTL square wave pulse output, at a frequency of 100 pulses/revolution. Fuel temperature was also broadcast for calculation of flowrate. A secondary water-to-fuel heat exchanger with temperature control prepares the fuel to the temperature required for testing as described in the CFR 40, Part 86 requirements [47].

Fuel consumption was also measured through the carbon balance method from the gaseous emissions. Integrated concentrations of $\mathrm{HC}, \mathrm{CO}$, and $\mathrm{CO}_{2}$ were used to calculate fuel consumption given known background carbon levels and hydrogen-to-carbon fuel ratio.

Airflow was measured using a Meriam Instrument Laminar Flow Element (LFE) Model 50MC2-6. The LFE recorded a maximum flow rate of $1007.0 \mathrm{cfm}$ at a temperature of $70^{\circ} \mathrm{F}$ and 29.97 inHg of absolute air pressure. The pressure drop across the LFE was measured with transducers, and measurements were also taken for absolute pressure and temperature. Meriam reported a manufacturer's calibration of $\pm 0.7 \%$ accuracy.

\subsubsection{Data Acquisition}

A data acquisition program developed by WVU was used to process digital codes sent from multiple Analog Devices 3B ADC modules, which received data from the analyzers. A 
WVU developed reduction program performed regression analysis, yielding continuous results and summary forms for each test performed [3].

\subsubsection{Engine Cycles}

Engine cycles were input to the dynamometer control system, created from in-use routes. Input parameters include time in seconds, set engine speed and torque in at a $1 \mathrm{~Hz}$ rate. $\mathrm{A} 5 \mathrm{~Hz}$ linear interpolation was used in the control of the engine. Engine maps were created on the dynamometer when possible. If not created on the dynamometer, engine maps from the manufacturer were implemented. Steady state tests were performed at rated power and rated torque basis. Three hot start FTP tests were reported; this is a deviation of the CFR 40, Part 86 certification protocol, which also suggests cold FTP operation [47]. Engine operating parameters were set according to the manufacturers' specifications unless specified in the CFR 40, Part 86., unless the test focus required otherwise These conditions include intake and ambient air temperature, fuel temperature, intake depression and exhaust backpressure, and intercooler temperature.

Continuous data from in-use routes was converted to $1 \mathrm{~Hz}$ data of speed, torque, and power, and input into the dynamometer control system. Time between cycles was minimized to facilitate maximum repeatability of ambient and operation conditions. The reduced time also aided in recreating the in-use testing in the laboratory, as in-use routes were completed uninterrupted when viable.

\subsubsection{Calibration Gases}

Concentrations of calibration gas were set to insure maximum analyzer resolution while avoiding analyzer over-ranging during tests. Standard Reference Material (SRM) bottles and gas chromatography equipment was used to specify more accurate measurements of several gas bottle concentrations, when difficulty arose in properly calibrating analyzers.

\subsubsection{Gas Divider}

A STEC Inc. model SGD-710C capillary gas divider was used in analyzer calibration. Calibration was performed according to CFR 40 Part 86 instructions; with $0 \%$ to $100 \%$ span gas bottle concentrations in $10 \%$ increments [47].

\subsubsection{Operating Procedures}

Dynamometer emission testing was performed in accordance with CFR 40 [47]. Test procedures for in-use cycle testing followed procedures for FTP certification cycles when 
applicable. MEMS calibration was performed according to standards reached in agreement between the EPA and settling manufacturers for Phase II testing [48].

\subsection{Mobile Emissions Measurement System (MEMS)}

Five in-use emissions measurement systems, one of which is pictured in Figure 3-1, were developed to fulfill the requirements for the settling manufacturer Consent Decrees, the units identical in hardware and software construction. The systems were capable of measuring brakespecific mass emissions from HDDEs. The systems were able to measure $\mathrm{NO}_{\mathrm{x}}, \mathrm{CO}_{2}$, and fuel consumption. Engine parameters were recorded as well as ambient conditions.

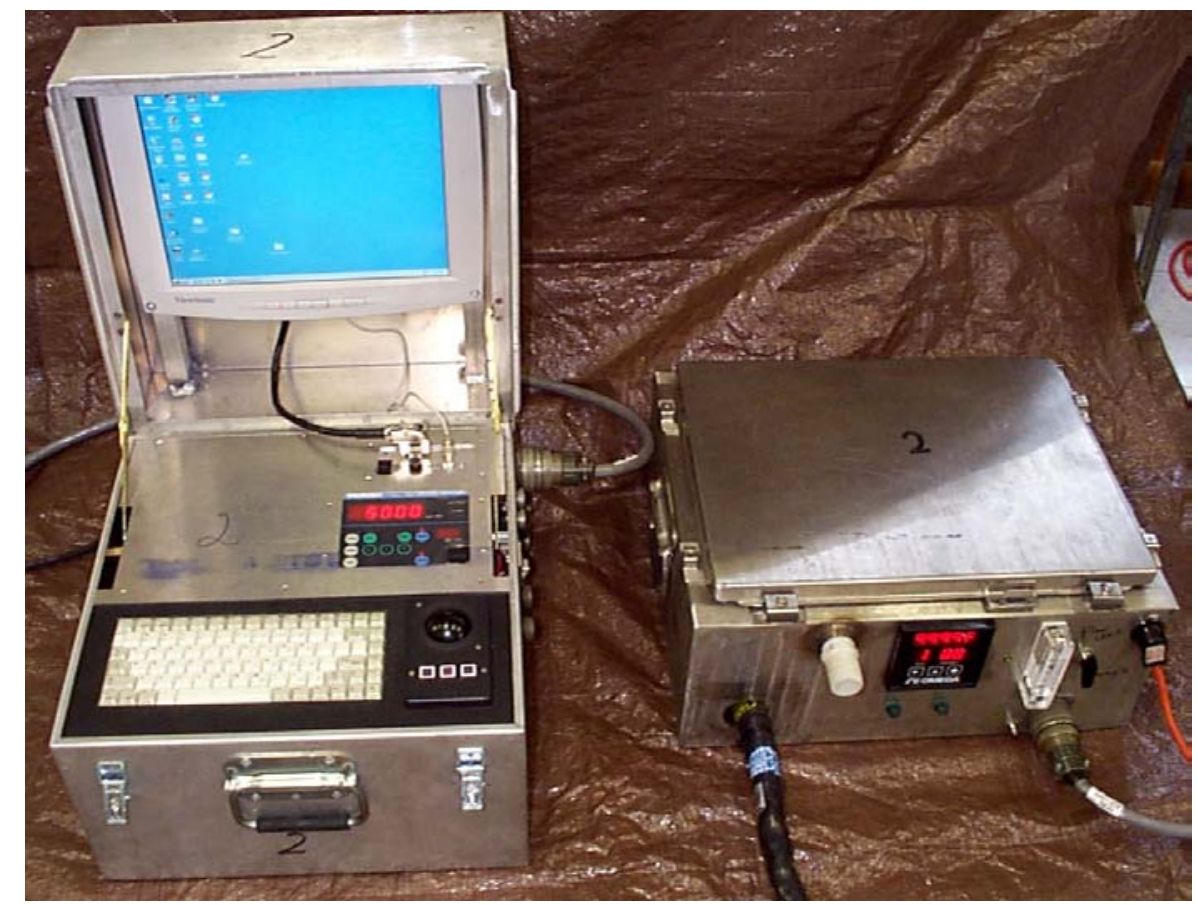

Figure 3-1: MEMS Data Acquisition and Emissions Measurement Components. Left Hand Module is the Data Acquisition System; Right Hand Module is the Emission Measurement System [49]

The systems used for on-road measurement were also used in engine dynamometer correlation and system validation tests. No changes were made from the system for test cell implementation, with the exception of deactivation of the GPS unit in the engine dynamometer tests, and any of the five units may have been employed at any given time. Variance measured in cycle generation is therefore inherently inclusive of the variance from module to module.

\subsubsection{Gaseous Emissions Sampling System}

The gaseous sampling system operated under principles consistent with engine certification testing. A diagram of system components is displayed in Figure 3-2. The sample 
was maintained above dew point temperatures and transported in non-reactive environments.

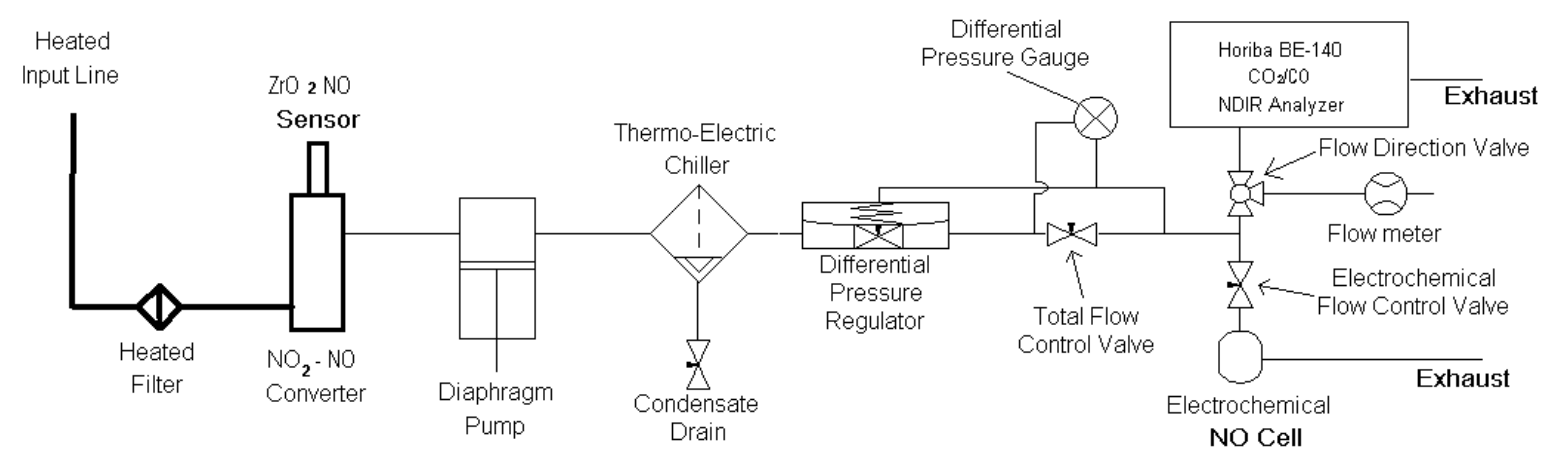

Sample Line Legand

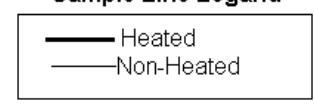

Figure 3-2: MEMS Sample Flow Schematic [49]

\subsubsection{Probe and Heated Sampling Line}

An exhaust sample probe was placed in the exhaust pipe in accordance to the CFR Part 89 probe specifications [2]. A 1/4 inch outside diameter stainless steel tube was drilled with three sets of three 5/64 inch sample holes located every 120 degrees radially, as seen in Figure 3-3. The center set of holes was located in the center of the flow, with the other two sets of sampling holes located $1 / 4$ exhaust pipe diameters from the wall of the pipe.

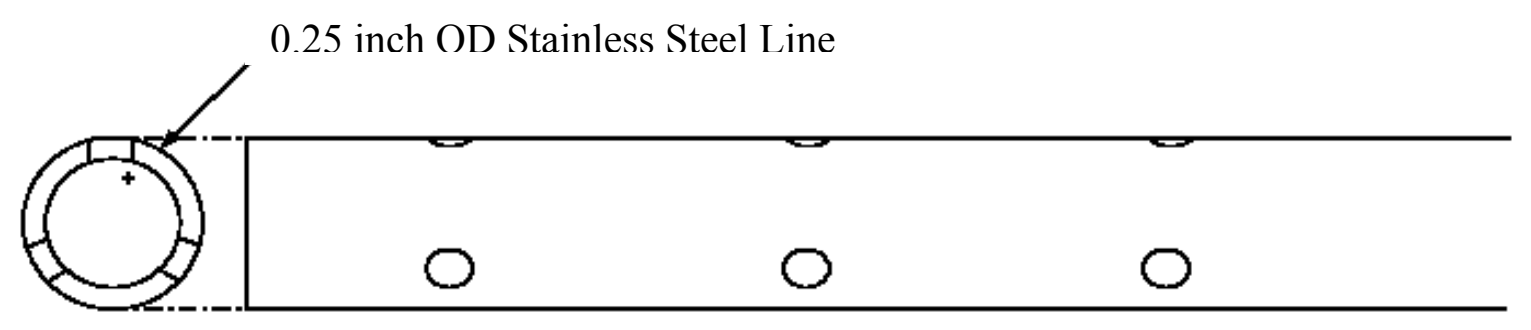

Figure 3-3: Raw Exhaust Gas Sampling Probe [2]

The probe outlet led to a three-way stainless steel valve via insulated stainless steel tubes. The second input to the valve was a Teflon tube from calibration gas bottles. Following the valve, a heated 1/4 inch Teflon line transported the sample to a heated filter. The filter used replaceable $2.5 \mathrm{x}$ 1inch high temperature cartridges to remove PM from the sample to protect the 
analyzers and diaphragm pump. The sample was heated above the dew point to avoid condensation and $\mathrm{NO}_{\mathrm{x}}$ reactions that occur with differing thermal conditions.

\subsubsection{Diaphragm Pump}

The exhaust sample was directed to the analyzers by an Air Dimensions Inc. Micro Dia$\operatorname{Vac} \AA$ oil free sample pump. The pump requires 115 volts and 1.9 amperes of current. The pump was unheated and located downstream of the MEXA $\mathrm{NO}_{\mathrm{x}}$ sensor.

\subsubsection{Sampling System Temperature Measurements}

Temperature was also measured in order to monitor and control the emission sampling system. An Omega CN616 temperature controller maintained a heated sample line temperature of $250{ }^{\circ} \mathrm{F}$, a heated filter temperature of $300^{\circ} \mathrm{F}, \mathrm{NO}_{\mathrm{x}}$ converter temperature of $400{ }^{\circ} \mathrm{F}$, a chiller temperature of $45^{\circ} \mathrm{F}$, and air temperature of $100^{\circ} \mathrm{F}$ in the area neighboring the chiller unit and sample pump. The controller also reported air temperature of the emissions box adjacent to the heated filter.

\subsubsection{Calibration and Calibration Gasses}

Nitrogen gas was used as a balance for both the $\mathrm{NO}_{\mathrm{x}}$ and the $\mathrm{CO}_{2}$ bottles. $\mathrm{NO}_{\mathrm{x}}$ span concentrations were approximately $2000 \mathrm{ppm}$. $\mathrm{CO}_{2}$ span gas was approximately $12 \%$. Gasses concentrations were regulated via a capillary gas divider, with increments of ten percent from zero to span. Calibration gasses entered the analytical system upstream of the heated Teflon line. An atmospheric bleed off line was used to insure positive pressure in the calibration gas line, moreover to avoid over pressuring the diaphragm pump inlet.

\subsubsection{NO $_{\mathrm{x}}$ Analyzers}

Two methods of $\mathrm{NO}_{\mathrm{x}}$ measurement were employed in the MEMS system. An EC cell and $\mathrm{Z} \mathrm{ZrO}_{2}$ sensor both reported concentration levels. The EC was installed as a QA/QC device in the event of $\mathrm{ZrO}_{2}$ failure.

\subsection{NO Converter Catalyst}

Proprietary $\mathrm{NO}_{2}$ to $\mathrm{NO}$ catalyst was placed downstream of the heated filter. Though the MEXA $\mathrm{NO}_{\mathrm{x}}$ manufacturer claims effective $\mathrm{NO}_{\mathrm{x}}$ measurement, laboratory tests have shown inaccuracies in conversions as high as $75 \%$ at high $\mathrm{NO}_{2}$ levels [2]. The catalyst, placed upstream of the sensors, encouraged accurate $\mathrm{NO}_{\mathrm{x}}$ measurement.

\subsection{MEXA NO Analyzer}

The $\mathrm{ZrO}_{2}$ based MEXA NO${ }_{\mathrm{x}}$ sensor was capable of concentration measurements from 0 
to $5000 \mathrm{ppm} \mathrm{NO}_{\mathrm{x}}$. Sample gas was passed through the sensor, which was approximately the size of an automotive oxygen sensor. The sample gas traveled through two chambers in the sensor. The first chamber removed free oxygen molecules in the sample, passing the molecules through a section of the chamber wall that was energized $\mathrm{ZrO}_{2}$.

The sample then entered the secondary internal cavity and was dissociated into $\mathrm{N}_{2}$ and $\mathrm{O}_{2}$. An energized $\mathrm{ZrO}_{2}$ plate pumped the generated $\mathrm{O}_{2}{ }^{-}$ions out of the second chamber. The current required to remove the oxygen from the second chamber was proportional to the amount of NO in the chamber. To insure effectiveness of the dissociation and mitigation in the chambers, the sensor was maintained at $1292^{\circ} \mathrm{F}\left(700^{\circ} \mathrm{C}\right)$. The average life of a sensor under normal operating conditions is 100,000 vehicle miles [50].

Some limitations in the sensor were its vulnerability to ammonia contamination and the possible erroneous NO measurement under high $\mathrm{CO}$ and $\mathrm{HC}$ concentrations. The ammonia response was not an issue, but problems may arise in systems with high ammonia concentrations such as urea injection aftertreatment devices. The $\mathrm{CO}$ and $\mathrm{HC}$ emissions from diesel engines are generally low due to their lean burn nature, reducing the risk of contamination.

\subsection{EC NOx Analyzer}

EC cells operate on the principle of membrane diffusion, where the current output from the sensor was proportional to the concentration of the target gas in the sample. The EC cell in the MEMS unit was a Cititech AMBII $\mathrm{NO}_{\mathrm{x}}$ cell, with a range of 0 to 5000ppm. The cell was placed downstream of the NO catalyst, since the cell did not readily recognize $\mathrm{NO}_{2}$. The response time of the sensor was approximately 5 seconds, and the relative humidity of the sensor was required to remain above $15 \%$ to avoid EC depletion [2]. This was not achieved, as maintaining a higher humidity would require passing a hot sample gas through the system, and the required sample temperature of $250^{\circ} \mathrm{F}$ would deplete the cell.

\subsubsection{6 $\mathrm{CO}_{2}$ Analyzer}

An NDIR Horiba Model BE-140 measured $\mathrm{CO}_{2}$ emissions. The analyzer was capable of evaluating levels of $\mathrm{CO}, \mathrm{HC}$, and $\mathrm{CO}_{2}$ and transmitting results at a nominal rate of $5 \mathrm{~Hz}[51]$. Hydrocarbons of a raw sample may condense in the lines, which may harm or bias this analyzer. To avoid HC bias, a chiller was placed upstream of the EC and NDIR analyzers. Due to these factors and the fact that $\mathrm{NO}_{\mathrm{x}}$ and $\mathrm{CO}_{2}$ were the species of primary concern, $\mathrm{HC}$ and $\mathrm{CO}$ measurements were not reported. 


\subsubsection{Exhaust Flow Measurement}

An Annubar Diamond flow model DCR device was placed in the exhaust stream to measure instantaneous exhaust flow rate. The Annubar requires 8 diameters upstream and 4 diameters downstream of straight pipe for accurate flow measurement. The device was a diamond shaped probe with edges aligned parallel and perpendicular to the flow field, as seen in Figure 3-4 [52]. The flow differential was measured from the stagnation point and the suction point, the upstream and downstream ports respectively.

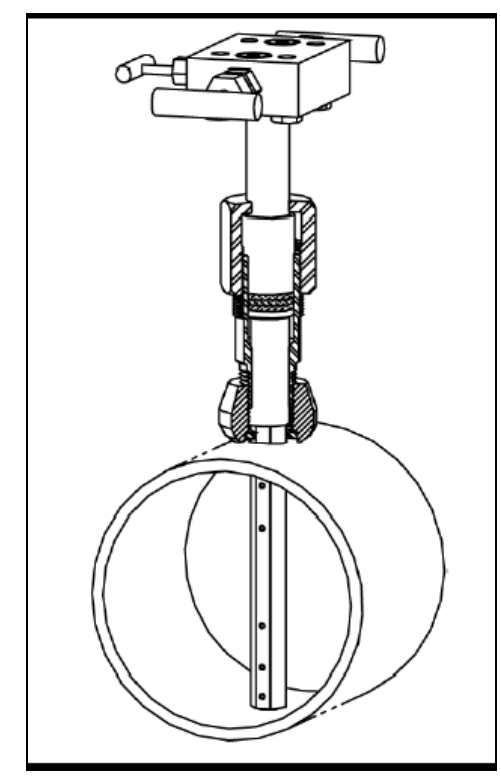

Figure 3-4: Annubar Flow Measurement Device [52]

The differential flow ports were connected to a pressure transducer, Validyne model P55D. The transducer returned a voltage proportional to pressure differential, which was mathematically converted into a velocity flow rate. Corrections to standard conditions were necessary. An Omega model PX213 transducer measured absolute pressure. Equation 3 describes the Annubar flow equation [53].

$$
Q=F_{N A} * K * D^{2} * F_{R A} * Y_{A} * F_{P B} * F_{t b} * F_{T F} * F_{G} * F_{P V} * F_{M} * F_{A A} * F_{L} * \sqrt{h_{w}} * \sqrt{\rho_{F}}
$$

\section{Equation 3}

Where $\mathrm{Q}$ is the volumetric flow rate, which was converted to mass flow rate by multiplying by fluid density; $\mathrm{F}_{\mathrm{NA}}$ is a unit conversion factor, 5.6362; $\mathrm{K}$ is a flow coefficient, 0.6264; $\mathrm{D}$ is the inner pipe diameter in inches; $\mathrm{F}_{\mathrm{RA}}$ is the Reynolds number correction factor, equal to $1 ; \mathrm{Y}_{\mathrm{A}}$ is the gas expansion factor, equal to $1-0.00585^{*}\left[\Delta \mathrm{P} /\left(\mathrm{P}_{\mathrm{F}} * \mathrm{k}\right)\right]$, where $\Delta \mathrm{P}$ is the differential pressure; $\mathrm{P}_{\mathrm{F}}$ is the absolute pressure; and $\mathrm{k}$ is the isentropic gas constant. $\mathrm{F}_{\mathrm{PB}}$ is the 
pressure base correction factor, 1.0023; $\mathrm{F}_{\mathrm{TB}}$ is the temperature correction factor, 1.0154; $\mathrm{F}_{\mathrm{TF}}$ is the flowing temperature correction factor, calculated as $\left[520 /\left(\right.\right.$ Temperature Base $\left.\left({ }^{\circ} \mathrm{F}\right)+460\right] ; \mathrm{F}_{\mathrm{G}}$ was the specific gravity factor, set as $1 ; F_{M}$ was the manometer correction factor, also $1 ; F_{A A}$ is the thermal expansion correction factor, found empirically from the following equation, where $\mathrm{T}$ is the temperature in degrees Fahrenheit: $\mathrm{F}_{\mathrm{AA}}=2.9786^{-9} * \mathrm{~T}^{2}+1.2620^{-5}(\mathrm{~T})+0.99912$; the location correction factor, $\mathrm{F}_{\mathrm{L}}$, was set as 1 ; the $\mathrm{h}_{\mathrm{w}}$ term is the square root of differential pressure measured by the pressure transducers; the $f$ term is the square root of the fluid density, both previous terms appearing in the equation due to the fundamental Bernoulli's principle.

Two J-type thermocouples measured exhaust temperature, one upstream and one downstream of the Annubar in the raw exhaust flow. The pre-Annubar thermocouple range was 0 to $500{ }^{\circ} \mathrm{F}$, and the range of the post-Annubar thermocouple was 0 to $750^{\circ} \mathrm{F}$. A higher temperature range for the post-thermocouple was selected in the case of over-ranging the prethermocouple, at a sacrifice of resolution. The temperature in the exhaust was employed in flow rate correction equations.

\subsubsection{Engine Load and Speed Measurement}

Engine percent load and engine speed were acquired via the diagnostic port of the engine ECU via a Dearborn or T6 protocol adaptor. These two parameters allowed for the calculation of engine torque given a known torque vs. speed lug curve [54]. The lug curve was supplied by the engine manufacturer with the exception of the engines tested on the dynamometer, for which the lug curve was generated.

No-load was set as measured percent load rate under engine idle conditions, determined by running the engine through a prescribed set of engine speeds with the transmission in neutral. Figure 3-5 displays an example lug curve used in torque inference equations. The upper most boundary is the maximum engine percent load available at the speed described by the x-axis. The bell shaped curve in the center of the plot is the maximum available torque at 100 percent load for each engine speed. The lower curve is the broadcast percent load necessary to operate the engine at idle for the given engine speed, which defines the no-load during torque calculations. This was set as the no-load point for each engine speed, accounting for engine accessories and fuel required to overcome engine friction at the particular speed. 


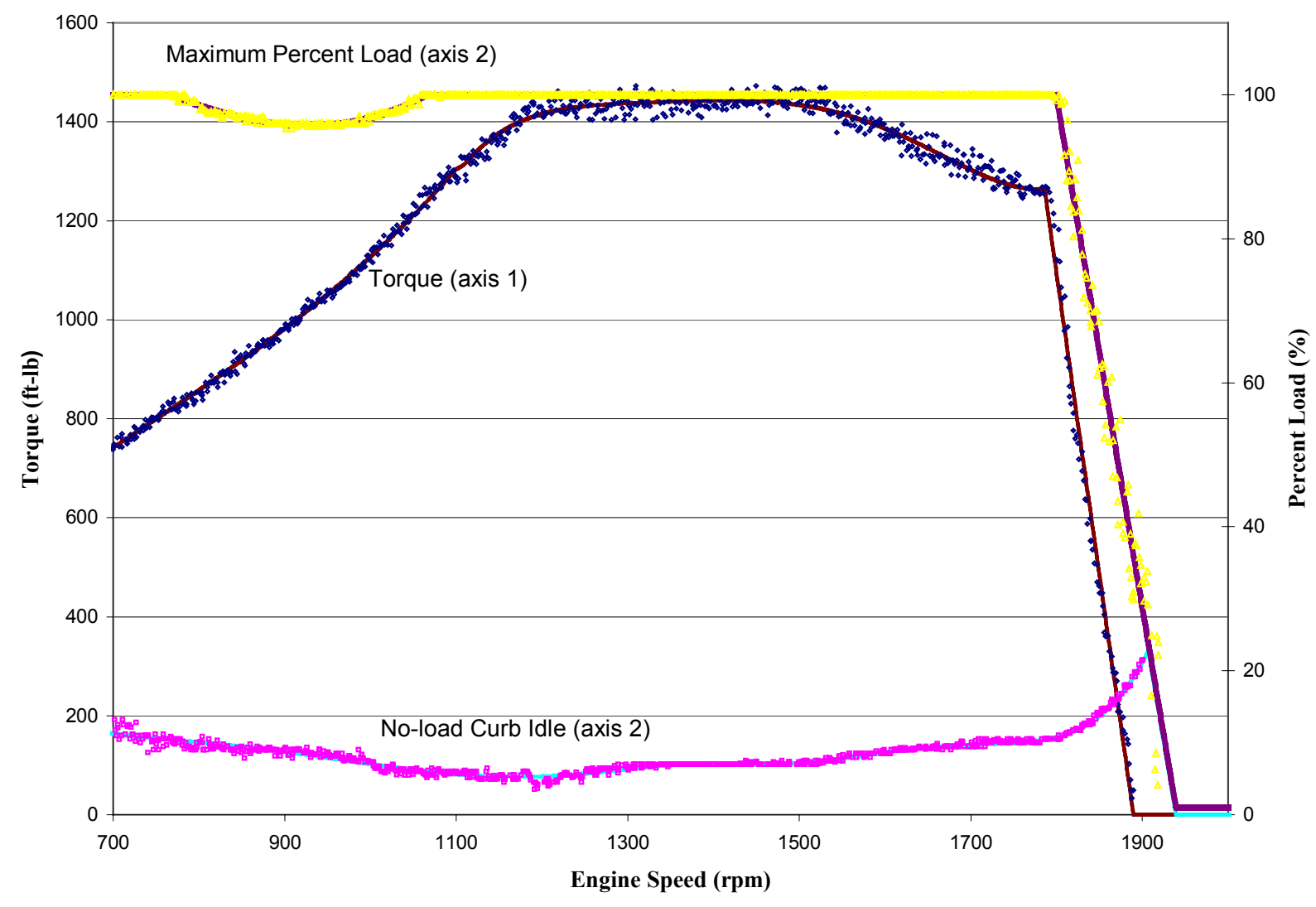

Figure 3-5: Example of Generated Engine Lug Curve

Failure to use the curb idle during torque calculations resulted in higher energy specific emissions results, as the power inferred would decrease. Thompson et. al [54] describe the procedure for inference of torque at any level of operation by implementing Equation 4, where $\mathrm{T}^{\mathrm{rpm}}$ is the torque at a given engine speed, and $\mathrm{ECU}^{\mathrm{rpm}}{ }_{\mathrm{j}}$ is the rpm broadcast by the ECU at $\mathrm{j}$ condition. This equation overestimated the actual load as it assumed that friction is a function of engine speed only, whereas in actuality it was also a function of engine load.

$$
T^{r p m}(t)=\left(\frac{E C U_{\%}^{r p m}-E C U_{\text {no-load }}^{r p m}}{E C U_{\% \max }^{r p m}-E C U_{n o-l o a d}^{r p m}}\right) * T_{\text {max }}^{r p m}
$$

Equation 4

The US EPA and CARB defined Not-To-Exceed (NTE) zones of operation for future certification, displayed in Figure 3-6. The 15\% ECS speed was calculated as $n_{10}+0.15\left(n_{h i}-n_{l o}\right)$. 
Where $n_{l o}$ is the lowest engine speed where $50 \%$ maximum power is available, and $n_{h i}$ is the highest speed where $70 \%$ maximum power is available. In 2007, emissions limits in this zone are to never surpass a value of 1.5 times the certification limit achieved during the FTP cycle. MEMS records windows of 30 second or more of NTE zone operation.

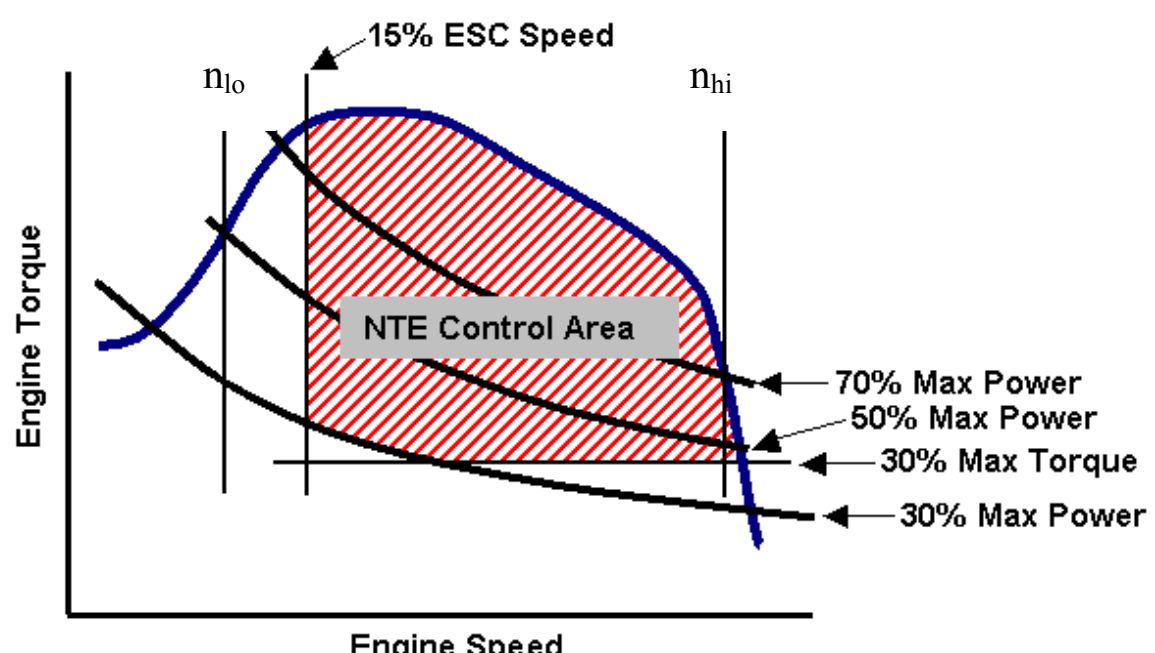

Figure 3-6: Graphical Definition of NTE Zone for Gaseous Emissions [3]

\subsubsection{Global Positioning Sensor}

A Garmin GPS 35/36 was mounted on each vehicle during MEMS equipment installation. The GPS served as a redundant method for measurement of vehicle speed, and was used in the absence of broadcasted ECU speed. The GPS unit also allowed for tracking the vehicle in route.

\subsubsection{Ambient Condition Measurement}

Ambient conditions including temperature, pressure, and humidity were measured to covert test measurements to standard conditions in accordance with the requirements of the CFR 40, PART 86 [47]. Temperature in the "ambient box" was measured using a solid state sensor. A relative humidity sensor reported humidity, and a pressure transducer measured ambient pressure. The ambient box was included to record trends of conditions as a test progressed. Future MEMS units may use this continuous data for reduction purposes, provided accuracy and reliability improvements are achieved.

For reduction and analysis purposes more reliable and accurate methods were implemented for ambient condition measurements. Temperature was recorded using a dry bulb 
mercury thermometer or a digital weather station. Relative humidity was recorded from a sling psychromoter or digital station, and ambient pressure was read from a HEISE Model PTE-1 handheld digital calibrator, with pressure transducer modules with a manufacturer claimed accuracy of $\pm 0.06 \%$. This data was input into $\mathrm{NO}_{\mathrm{x}}$ dry-wet correction equations.

\subsubsection{Calibration Procedures}

MEMS calibration was performed in accordance to the agreements made in Phase II of the Consent Decree in-use testing [48]. Gaseous analyzers and pressure transducers were calibrated prior to SAB2BM, SAB2SW, Morgantown, WASHPA1 and WASHPA3 routes. Additional calibrations were performed when deemed necessary by operators to insure the validity of data. When dynamometer testing, calibrations were performed prior to the initial tests and following two consecutive cycles.

\subsubsection{Data Acquisition and Reduction}

WVU developed a data acquisition system as well as reduction software for efficient handling of data. The user interface for the data acquisition system consisted of a common flat panel monitor, keyboard, and mouse. Data was collected via a National Instruments modular signal conditioning system. A standard $30 \mathrm{~GB}$ laptop hard drive recorded files, operating MS Windows on an Advantech PCM 95705 mother board, capable of $800 \mathrm{MHz}$ processing with 128 MB of RAM. The data was conditioned by a National Instruments SC-2345 unit with 6024-E cards. 


\section{Vehicle Selection}

Vehicles were selected in accordance to the stipulations of Phase III of the Consent Decrees, as a representation of typical fleet vehicles in operation which meet the Phase III criteria. Vehicles were rented, borrowed, or leased from dealerships and rental companies. Vehicles were approved by the EPA and the manufacturer of the engine, and loaded to within $95 \%$ of the GVWR. One vehicle from each manufacturer was selected for engine dynamometer testing for validation purposes.

A total of 36 vehicles were tested for this study. Caterpillar, Detroit Diesel Corporation, Cummins, International/Navistar, Mack, and Volvo manufactured the engines in the vehicles. The vehicles ranged in weight from 15,000lbs to $80,000 \mathrm{lbs}$ Gross Vehicle Weight Restricted (GVWR).

The engines ranged in size from 7.3 to 15.8 liters, and had a wide range of transmissions. Fuel used in testing was drawn from local public pumps as the vehicles arrived. All vehicles were inspected for safety prior to testing, and certified operators conducted driving. Due to the sensitivity of the data from these studies, individual results, vehicle, and engine specifications were not presented. 


\section{On-Road Routes}

The in-use testing conducted in this research was performed by WVU as a fulfillment of Phase III of the Consent Decrees signed by the EPA and the settling HDDE manufacturers. Four routes were defined following Phase II by WVU in conjunction with the settling manufacturers and the EPA. The routes were meant to represent typical in-use vehicle applications, and consisted of both urban and highway segments. Two of the routes were comprised of primarily urban driving, while two routes were principally highway cycles. The following paragraph is a subsection of the Consent Decrees describing the route criteria [55]:

In Phase II of the In-Use Testing Program, the manufacturer shall develop in-use testing procedures to be used in connection with Phases III and IV of the In-Use Testing Program. The development of in-use testing procedures shall be based on testing of HDDEs engaged in a variety of typical on-road emissions, and in a variety of seasonal conditions, and shall utilize engines extending over various stages of their Useful Life. The testing procedures shall include the identification of candidate driving routes representing typical urban, suburban, and highway driving. The candidate routes shall be of sufficient length to take 45 minutes when driven at posted speeds. At least one (1) candidate driving route shall include a portion where at least 15 minutes of operation at $65 \mathrm{mph}$ or greater is permitted and generally attained by trucks.

One objective in using the routes was to remain in NTE zones for a minimum of 30 seconds [49]. It was determined some of the selected routes may have been unable to achieve 30 second NTE zones, due to low power demand during low-speed cruise and loss of engine shaft power when the clutch is disengaged. The urban routes generally yielded few NTE operation zones, while freeway driving typically includes NTE zones under sustained hill climbs or highspeed operation. Further details on routes, including street maps, are available in the report

presented to the EPA and settling manufacturers for the fulfillment of Phase III requirements [49]. The following route descriptions are excerpts from the aforementioned report.

\subsection{Saltwell, WV}

This route was split into outbound and return journeys. The route originated at the WVU Sabraton facility (Greater Morgantown Area) close to an entrance ramp accessing I-68 west. The route proceeded to I-79, and followed I-79 south to the turnaround point at the I-79 Saltwell Rd. Exit (near Clarksburg, WV). The total distance was 58.7 miles. The 
interstate was posted at $70 \mathrm{mph}$, but there were two curves with advisory signs below that speed. The outbound leg was designated SAB2SW and the return leg was designated SW2SAB [49].

\subsection{Bruceton Mills, WV}

This route was divided into outbound and return journeys. The route originated at the WVU Sabraton facility close to the Sabraton entrance ramp on I-68 east, and continued on I-68 where a climb of a sustained 5\% grade existed, followed by transient road grades to the turnaround point at Bruceton Mills, WV. The total distance was 39.7 miles. The interstate was posted at $70 \mathrm{mph}$, but the $5 \%$ descent on the return journey was posted at $50 \mathrm{mph}$ for trucks and was preceded by a mandatory truck stop for checking brakes. In the high-speed freeway operation, dramatic reductions in vehicle speed were encountered as the vehicle climbed the hills along the route. In the case of this route, truck speed restrictions and necessary precautions during the steep descent on the return leg of the journey reduced the operating speed on I-68 westbound. The outbound leg was designated SAB2BM, and the return leg was designated BM2SAB [49].

\subsection{Pittsburgh (Mt. Morris), PA}

This route originated in Washington, PA, which is located near the intersection of I-70 and I-79. The route proceeded from Washington on US Rte. 19 north through suburban areas toward Pittsburgh, followed PA State Rte. 51 (US truck Rte. 19) to I-279 south, to I-79 south, and then returned to the first rest area in West Virginia. For the first and second leg, the interstate speed limit was $55 \mathrm{mph}$, and the suburban road speed limits varied from 25 to $45 \mathrm{mph}$. The final leg consisted of all highway driving with a transition from $55 \mathrm{mph}$ to $65 \mathrm{mph}$. The total distance was 87.4 miles. The first leg was designated WASHPA1, the second leg as WASHPA2, and the third leg as WASHPA3 [49].

\subsection{Morgantown, WV}

This route originated at the WVU Sabraton facility and proceeded through suburban and urban settings on two and four lane roads, then joined I-79 south to I-68 east, to return to the starting point. The total distance was 20.4 miles. Posted speeds of 35, 40, and 50 mph existed on the urban and suburban routes, and the interstate sections were posted at $70 \mathrm{mph}$. Test vehicles with GVW in excess of $60,000 \mathrm{lb}$. were not operated over this route due to weight limitations associated with the Star City bridge that were imposed by the WV Department of Transportation during the time lapse between Phases II and III of this study [49]. 


\section{Evaluation of In-use Emissions Measurement}

In-use route measured engine speed and inferred torque data were used to create an engine dynamometer cycle to evaluate the MEMS system as described in the Consent Decrees. The variation of measured parameters was computed for the selected in-use routes and for the engine dynamometer generated cycles. Correlations were performed to analyze the variation in measurement from test cell data to MEMS data recorded on engine dynamometer testing, from MEMS test cell cycles to MEMS in-use routes, and between test cell cycles and MEMS in-use routes.

Variation also existed in engine performance and emissions due to performance related, ECU-related, and fuel related parameters. Performance related influences include temperature (air, coolant, oil, etc.) and pressure (barometric, inlet restriction, exhaust backpressure, etc.). ECU-related issues mainly involve fuel injection timing, which may be based on performance characteristics. Though manufacturers have some level of control of performance related and ECU-related parameters, they generally have no influence over the fuel used in the engine.

Inspecting the variation of routes and the ability to properly simulate an in-use route on an engine dynamometer via cycle generation, a perspective is gained which allows a general evaluation of an in-use measurement system.

\subsection{Variation of Vehicle Emissions for On-road Driving Cycles}

Each vehicle was driven on the previously described routes, or driving cycles. An analysis was performed to measure the variability of the on-road tests. Ongoing studies are being performed to measure the overall in-use repeatability in-depth; therefore this study will focus on a subsection of the test matrix, the Sabraton to Bruceton Mills route (SAB2BM). The investigation is performed for all MEMS Phase 3 engines tested on the engine dynamometer. Correlations were performed for work on a Bhp- $\mathrm{Hr}$ basis, and $\mathrm{NO}_{\mathrm{x}}$, and $\mathrm{CO}_{2}$ values on a $\mathrm{g} / \mathrm{Bhp}-$ $\mathrm{Hr}$ basis. To calculate the differences from run to run, the minimum value of a given parameter for a route was subtracted from the maximum value, and was normalized by dividing by the maximum value, as seen in Equation 5. A percentage value was given by multiplying the result by 100 . 


$$
\text { Percent Difference }_{\text {Max-Min }}=\frac{\text { Maximum Value }- \text { Minimum Value }}{\text { Maximum Value }} * 100
$$

Equation 5

It is noted the statistical difference values for the $\mathrm{MEXA} \mathrm{NO}_{\mathrm{x}}$ analyzer were typically lower than that of the EC measurement device, which was expected considering the technological advantage of the MEXA over the EC device. The EC was installed as a QA/QC device, and will not be accounted for in correlation calculations.

\subsection{Dynamometer Cycles and Corresponding On-Road Cycles}

The measurement of difference from generated dynamometer cycles and the corresponding in-use routes was also calculated. As in the in-use variability testing, the work, $\mathrm{NO}_{\mathrm{x}}$, and $\mathrm{CO}_{2}$ measured values were the focal point of the study. For analysis, the emissions and work data were reported on an integrated basis. One in-use cycle for SAB2BM was selected as discussed in the cycle generation section of this thesis. The generated dynamometer cycle was repeated at least three times. Equation 6 measured the difference from the in-use to in-cell MEMS measurements, where road signifies an in-use measurement and cell represents a measurement taken in the test cell. The road measurement was the data from the single run selected for reproduction only.

$$
\text { Difference }_{M E M S_{\text {cell to Road }}}=\text { average }\left(\frac{M E M S_{\text {road }}-M E M S_{\text {cell }}}{M E M S_{\text {road }}}\right) * 100
$$

Equation 6

The difference was also measured between the test cell SAB2BM cycle and the original in-use SAB2BM selected route MEMS data. The variance measurement technique of Equation 7, where Cell represents the test cell data recorded from the dynamometer cycle generated from the corresponding $\mathrm{MEMS}_{\text {road }}$ cycle. The road measurement was the data from the single run selected for reproduction only.

$$
\text { Difference }_{\text {Cell to MEMS On-Road }}=\text { average }\left(\frac{\text { Cell }-M E M S_{\text {road }}}{\text { Cell }}\right) * 100
$$




\subsection{Comparison of Engine Dynamometer and Mobile Emissions Measurement System}

The correlations between the laboratory analyzers and the MEMS analyzers provided a validation of the MEMS systems. The differences was calculated, and may be considered the error in the MEMS system, calculated with Equation 8. The average is the average of the three SAB2BM cycles exercised. All cycles were performed back to back, to minimize variables that may affect the test such as ambient conditions.

$$
\text { Difference }_{\text {Cell }}=\text { average }\left(\frac{\text { Cell }-M E M S_{\text {Cell }}}{\text { Cell }}\right) * 100
$$

Equation 8

An example of the continuous data for $\mathrm{NO}_{x}$ emission mass rate for a generated SAB2BM route engine dynamometer cycle is displayed in Figure 6-1. The data displayed has been time shifted to match emission events. The $\mathrm{NO}_{\mathrm{x}}$ correction factor equation described in CFR 40 Part 86 [47] was used for both measurement systems. The correction factor accounted for ambient conditions which effect the chemical properties such as humidity which contribute to the $\mathrm{NO}_{\mathrm{x}}$ production. Figure 6-1 is an example of continuous $\mathrm{NO}_{\mathrm{x}}$ measurement data, presented to illustrate how the integrated data may vary between different measurement systems due to continuous data variations.

Note the EC measurement was the highest of the three, a trend consistent in the other 6 engines analyzed. The laboratory analyzers and the MEXA analyzer were closer in relation, with the MEXA reading slightly higher than the laboratory. A discussion of the sources of error is given in Chapter 7. 


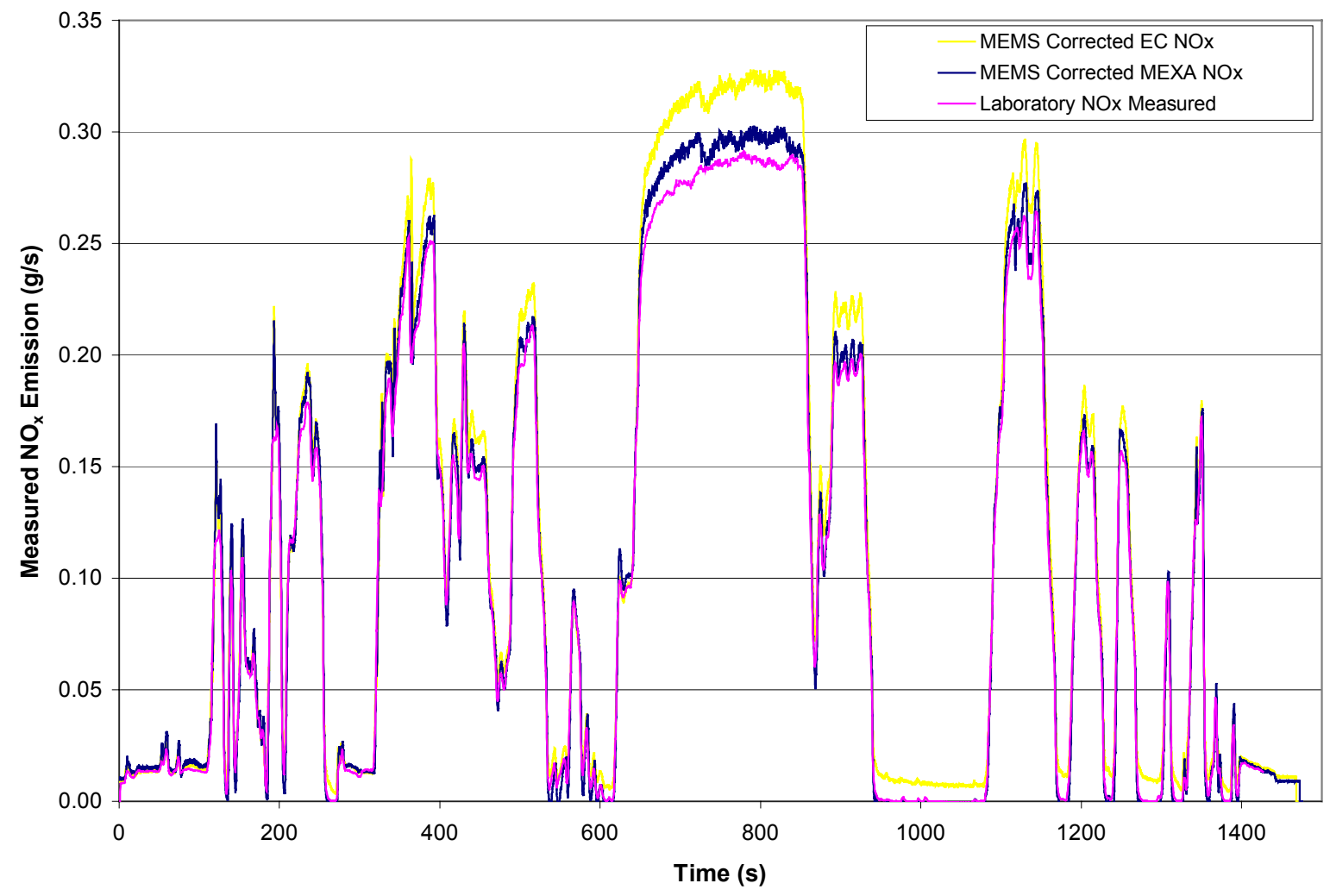

Figure 6-1 Example of Continuous Diesel Engine NO $_{x}$ Emission Measurement From MEXA, EC, and Laboratory Analyzers for SAB2BM Dynamometer Cycle

\subsection{Factors Effecting Engine Performance and Emissions}

Several factors were shown to effect engine emissions and shaft power output. Major factors available for control and analysis at the WVU EERC were fuel type, fuel temperature, intake air temperature, intercooler temperature, intake restriction and exhaust depression.

The shaft power output and emissions are a function of these parameters due to engine control strategy, chemical, and combustion events. The engine's controller may alter injection timing or duration due to measured operating characteristics, such as ambient air temperature. Engine control strategies were not accessible, nor were studies performed to determine algorithms that may depend on operating conditions.

Chemical events closely control combustion events. An increased temperature decreases air density, which may decrease ignition delay. An increase in fuel viscosity will could decrease 
the leakage in the fuel pumps, especially in constant volume pumps used on many light and some medium duty engines [35]. These characteristics, along with other measured conditions, are discussed in latter sections of this thesis.

\subsubsection{Fuel Characteristics}

Fuel quality is known to alter combustion characteristics and subsequently emissions and work out of an engine. Fuels used for in-use testing were drawn from local public filling stations near the selected routes. Though adding variance to the tests, mixing fuels brands was typical of vehicle operation and was necessary to properly quantify in-use vehicular emission. Five fuels were selected for analysis.

Kroger diesel fuel was drawn from a pump in Sabraton, WV, used in several on-road tests. Diesel was also taken from Citgo stations in Mt. Morris, PA and on Beechurst Avenue in Morgantown, WV. Mt. Morris diesel was used in many in-use tests since this was the location where the on-road vehicles were weighed on certified truck scales, and Beechurst was available for some smaller vehicles capable of operating on the Morgantown cycle. The fuels were also selected to show the variance of fuel between two stations with the same affiliation but differing locations. CARB fuel was selected due to its low sulfur and low aromatic content. This fuel was not used for on-road routes, but was chosen to broaden the variance of fuel quality study, since the specification is different from the 49 state diesel fuel. Guttman diesel was typically used in dynamometer testing at the WVU EERC for non-certification testing, and was not used for inuse vehicle testing.

Fuel samples from this study were stored in high-baked epoxy phenolic lined steel pails until analysis. Table 6-1 displays the standard deviation and coefficient of variation (COV) of fuel properties for the five fuels tested. The standard deviation is given by Equation 9 and the COV values are calculated using in Equation 10.

$$
\text { Standard Deviation }=\sqrt{\frac{\sum_{i=1}^{n}\left(x_{i}-\bar{x}\right)^{2}}{n}}
$$

Where $\mathrm{x}_{\mathrm{i}}$ is the value of emission or power at interval $\mathrm{i}, \bar{x}$ is the average value of emission or power, and $\mathrm{n}$ is the number of data points. One standard deviation represents $68.3 \%$ 
of the data represented in the average. Two standard deviations represent $95.4 \%$ of the data in the average. The COV is the standard deviation divided by the average and multiplied by a factor of 100, yielding a percent of variation useful measuring variance.

$$
C O V=\frac{\text { St andard Deviation }}{\text { Average }} * 100
$$

Equation 10

It is noted the COV was a measurement technique for variation of a data model with Gaussian distribution characteristics, which may or may not be the case for individual test sets. The method is presented with the understanding it is not statistically ideal in all situations, and was meant as a method to aide in analysis only. Fuel specific properties and explanations are discussed in the subsequent sections. Fuel properties for the five fuels tested can be found in Appendix C, showing significant variance in several fuel properties. Fuel properties that are known to affect combustion quality are described in more detail below.

\subsubsection{Olefins, Aromatics, and Saturates}

Olefins, aromatics, and saturates were all tested by a third party using the following method. A fuel sample was placed on a column of glass packed with silica gel, of which the top layer was treated with fluorescent dyes. The fuel sample separates into bands of olefin, aromatic, or saturate according to their attraction to the gel. The fluorescent dyes separate and boundaries are measured under ultraviolet light [56].

Olefins are unsaturated double bonded open chained HC molecules [57]. When they are saturated with hydrogen, they form paraffins. Olefins rarely are present in crude oil, but are formed in the early stages of refining. Currently unregulated, Olefins are known to form smog [56]. Olefins ranged from $0.7 \%$ volume for Beechurst Citgo to $1.8 \%$ volume for Mt. Morris Citgo. 
Table 6-1: Variation of Fuels Tested

\begin{tabular}{|c|c|c|c|}
\hline Property & Average & $\begin{array}{c}\text { One Standard } \\
\text { Deviation }\end{array}$ & $\begin{array}{l}\text { Coefficient of } \\
\text { Variation (\%) }\end{array}$ \\
\hline Aromatics (\% volume) & 18.2 & 8.70 & 47.8 \\
\hline Olefins (\% volume) & 1.08 & 0.432 & 40.0 \\
\hline Saturates (\% volume) & 80.7 & 8.47 & 10.5 \\
\hline Hydrogen Content (\% weight) & 13.6 & 0.530 & 3.9 \\
\hline Kinematic Viscosity (cSt) & 2.28 & 0.251 & 11.0 \\
\hline Specific Gravity (-) & 0.832 & 0.0183 & 2.2 \\
\hline Total Sulfur (\%weight) & 0.0354 & 0.0102 & 28.8 \\
\hline API Gravity (deg API) & 38.7 & 3.78 & 9.8 \\
\hline Carbon (\% weight) & 86.3 & 0.520 & 0.6 \\
\hline Cetane Index (-) & 50.3 & 5.29 & 10.5 \\
\hline Cetane Number (-) & 49.5 & 6.23 & 12.6 \\
\hline $\mathrm{IBP}(\operatorname{deg} \mathrm{F})$ & 355 & 4.21 & 1.2 \\
\hline 5\% Recovery (deg F) & 384 & 13.5 & 3.5 \\
\hline 10\% Recovery (deg F) & 398 & 16.7 & 4.2 \\
\hline 20\% Recovery (deg F) & 419 & 19.5 & 4.6 \\
\hline $30 \%$ Recovery (deg F) & 440 & 19.4 & 4.4 \\
\hline $40 \%$ Recovery (deg F) & 462 & 17.7 & 3.8 \\
\hline $50 \%$ Recovery (deg F) & 487 & 13.8 & 2.8 \\
\hline 60\% Recovery (deg F) & 512 & 10.1 & 2.0 \\
\hline $70 \%$ Recovery (deg F) & 540 & 9.43 & 1.7 \\
\hline $80 \%$ Recovery (deg F) & 568 & 11.4 & 2.0 \\
\hline 90\% Recovery (deg F) & 601 & 15.5 & 2.6 \\
\hline 95\% Recovery (deg F) & 626 & 20.7 & 3.3 \\
\hline FBP $(\operatorname{deg} F)$ & 645 & 19.7 & 3.0 \\
\hline Recovery (\%) & 98.1 & 0.336 & 0.3 \\
\hline Residue (\%) & 1.14 & 0.114 & 10.0 \\
\hline Loss $(\%)$ & 0.720 & 0.356 & 49.5 \\
\hline Flash Point (deg F) & 147 & 1.68 & 1.1 \\
\hline
\end{tabular}

Aromatics are defined as carbon atoms arranged in a ring joined by aromatic bonds.

Benzene is the simplest example of this ring. Aromatics are also unsaturated hydrocarbons, and form naphthenes when fully saturated with hydrogen. Partial hydrogen saturation yields cyclic olefins [56].

Figure 6-2 displays the aromatic content of each fuel analyzed. Aromatic content is currently regulated in California, where CARB maximum standards are $10 \%$ by volume. Aromatic content ranged from 9.0\% volume for CARB fuel to $28.2 \%$ volume for Beechurst Citgo diesel, the lowest aromatic content available at local pumping stations tested was $14.3 \%$ for Mt. Morris Citgo. 


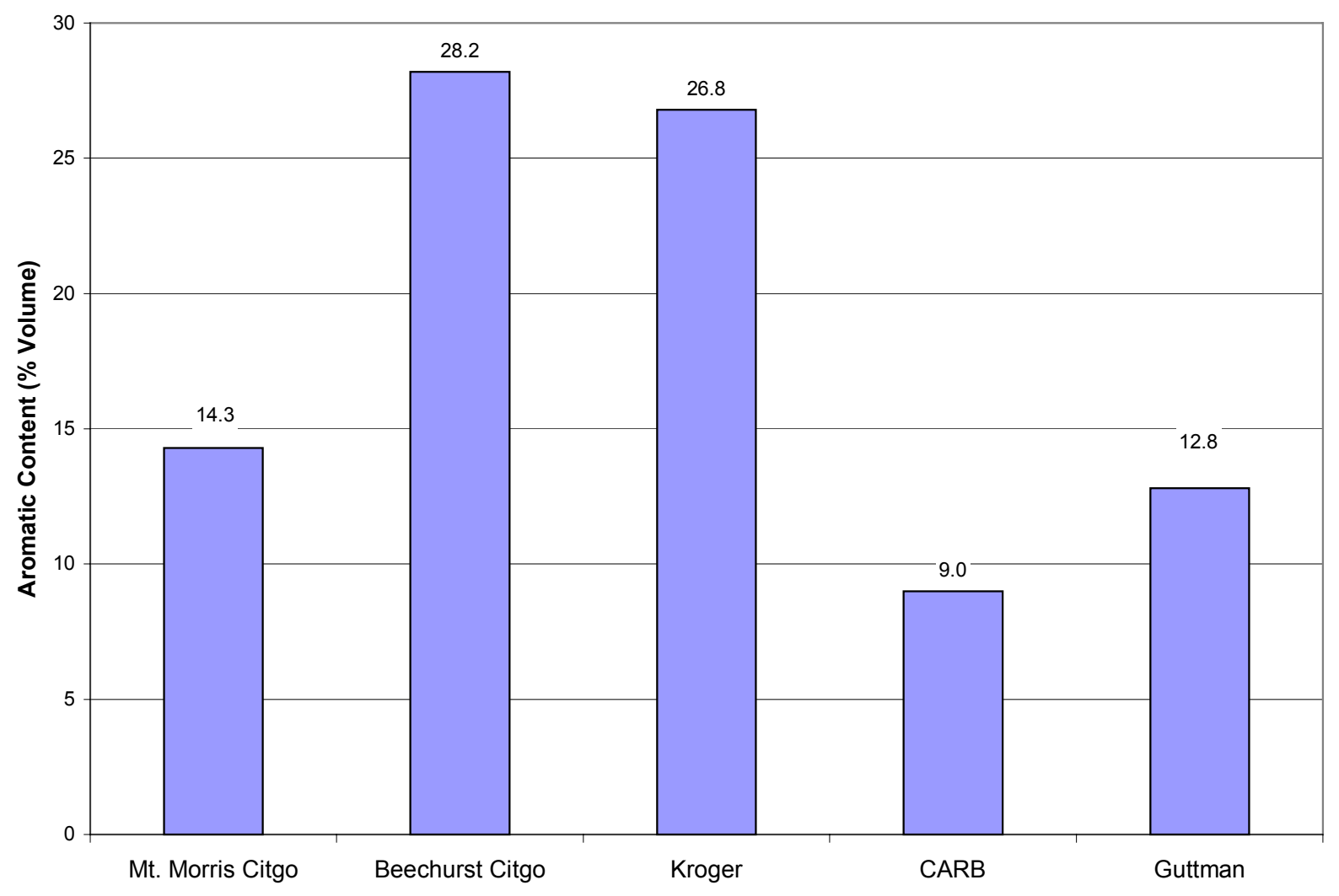

Figure 6-2: Aromatic Content of Fuels Tested

\subsubsection{Carbon-to-Hydrogen Ratio}

The carbon-to-hydrogen ratio of a fuel was necessary in calculating fuel consumption based on carbon content in exhaust. The percent weight of carbon was divided by the percent weight of hydrogen, and corrected to the atomic ratio by dividing the result by 12 . ASTM D 5291 standards were used by a third party for testing, and yielded a minimum C:H ratio of 1.79 for Beechurst Citgo diesel and a maximum value of 1.98 for CARB diesel fuel. The higher the paraffin content of a fuel, and the lower the aromatic content, the higher the $\mathrm{C}: \mathrm{H}$ ratio will be. This corresponds to the low aromaticity and high paraffin content of the CARB fuel.

\subsubsection{Specific Gravity and API}

The specific gravity of a fuel, also called relative density, is the ratio of the density of the fuel divided by the density of water, with both fluid temperatures held constant at $60^{\circ} \mathrm{F}$. Comparisons of fuel specific gravities are shown in Figure 6-3.

API is an arbitrary scale for measuring density. API gravity, in combination with the aniline point, is also used in calculating the diesel index of a fuel. An increase in API gravity 
generally represents low specific gravity and high paraffin content, leading to an increase in ignition quality [57]. As shown in Figure 6-3 and Figure 6-4, the fuel density (thus API) generally correlates to the cetane number.

The lowest specific gravity was found in Guttman fuel, a value of 0.810 . The highest specific gravity fuel was Beechurst Citgo, with a value of 0.849. The API gravity, an inverse relation to the specific gravity, yielded 35.2 degrees API for Beechurst Citgo and 43.2 degrees API for Guttman fuel.

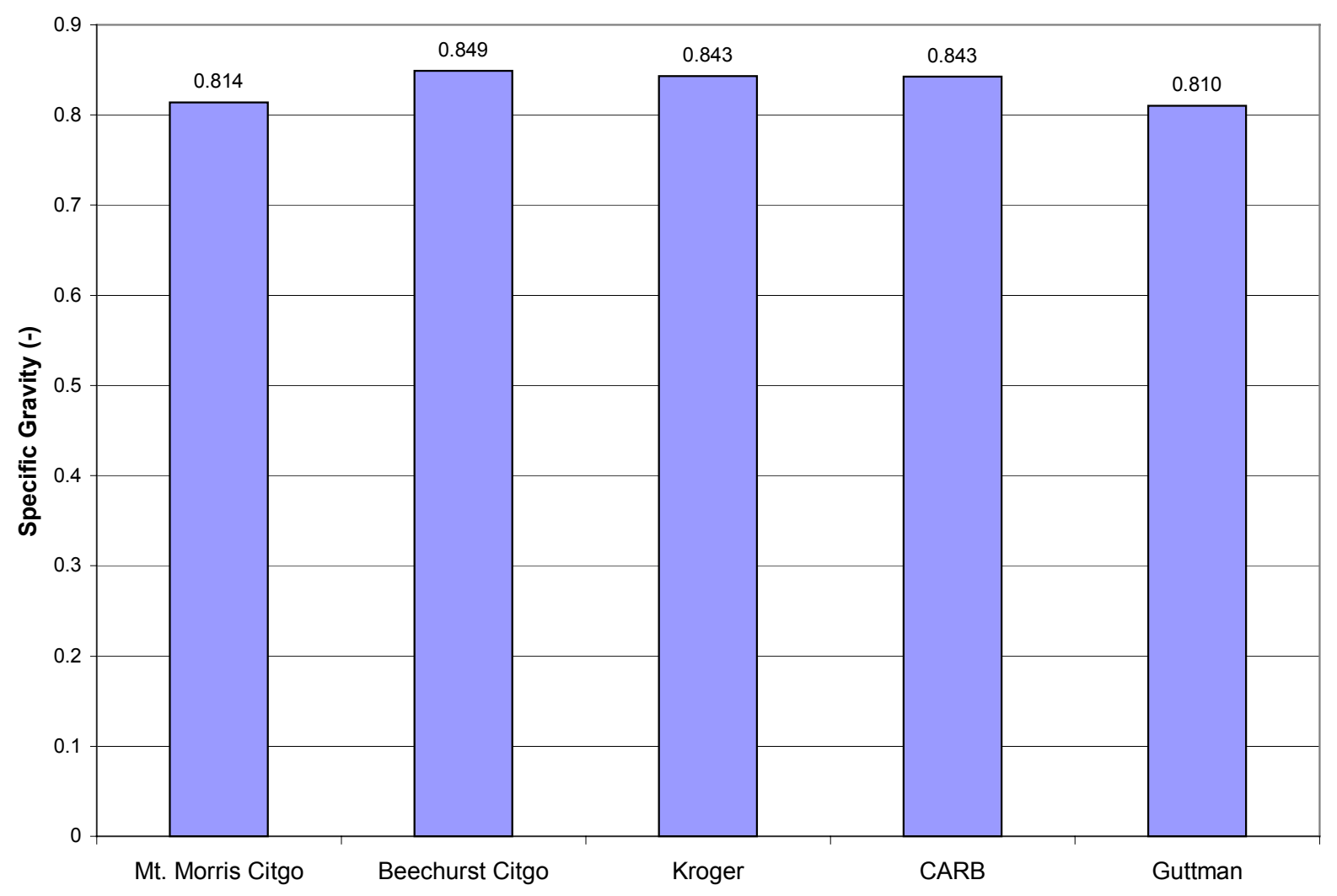

Figure 6-3: Specific Gravity of Fuels Tested

\subsubsection{Kinematic Viscosity}

Viscosity is the measurement of resistance a fluid has to a flow, and directly effects the atomization of fuel and the lubricity of fuel [56]. It is a modulus related to the molecular weight and structure of a substance. The fuels were tested by a third party, using ASTM D 445 kinematic viscosity tests, where the time required for a given volume of the fuel to flow through a viscometer tube is measured.

The ASTM D 975 regulation for kinematic viscosity allows a minimum of $1.9 \mathrm{cSt}$ and a 
maximum of $4.1 \mathrm{cSt}$. The kinematic viscosity ranged from $2.0 \mathrm{cSt}$ for Mt. Morris Citgo and 2.6 for the CARB fuel.

\subsubsection{Cetane Number and Cetane Index}

Cetane number is a representation of the ignition quality of a fuel and is based on the reference value of $n$-hexadecane $\left(\mathrm{C}_{16} \mathrm{H}_{34}\right)$ and heptamethylnonane. The cetane number was tested by a third party using operating procedures and conditions specified in ASTM Method D613 standards. A single cylinder, variable compression ratio CI engine was held at prescribed conditions, and the compression ratio was varied until ignition began at top center, with injection at 13 deg before TDC. [57]. Figure 6-4 displays a graphical comparison of the cetane numbers for the fuels evaluated. The minimum cetane number allowable for ASTM number 2 diesel for on-road use is 40. All fuels tested met this requirement, but significant variation existed, a 13\% COV as seen in Table 6-1. The CFR 40 part 86 requires the cetane number for a diesel-2 fuel to lie between 42 and 50 for certification testing [47]. It is noted the Mt. Morris Citgo and Guttman fuel both lie above this allowable range.

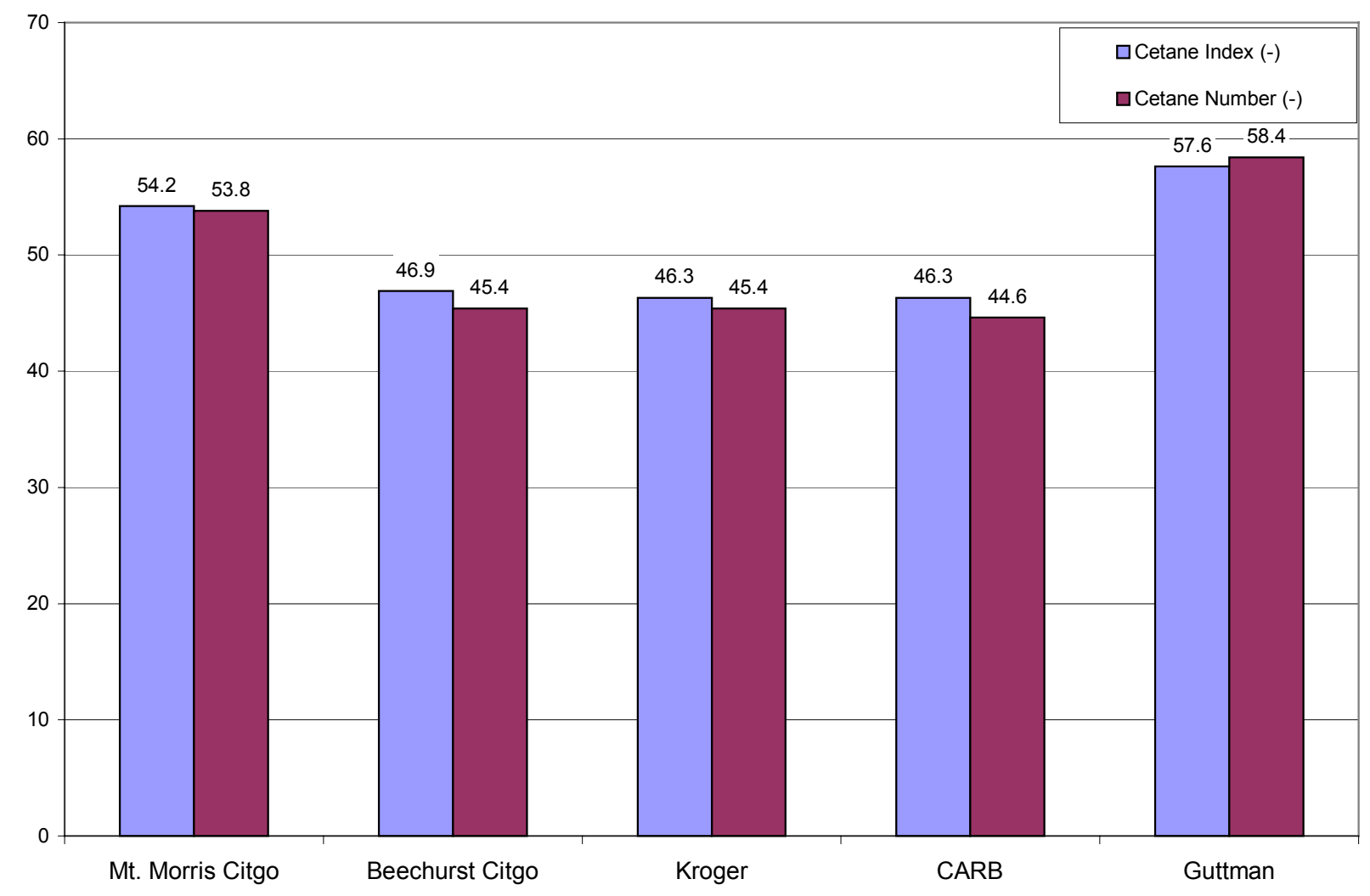

Figure 6-4: Cetane Number and Cetane Index of Fuels Tested 
Cetane index is a less expensive method of determining fuel ignition quality, and is calculated based on the aniline temperature where $50 \%$ of the fuel is evaporated and the API gravity of the fuel [57]. The cetane index is generally a fair representation of cetane number for straight-run fuels and catalytically cracked stocks, and provides a close relation to the cetane number for fuels in this study.

\subsubsection{Total Sulfur Content}

Sulfur is known to poison oxidation catalysts, and low sulfur fuels will be necessary if catalysts are implemented in future emission reduction programs. Also, catalysts designed for $\mathrm{HC}, \mathrm{CO}$, and $\mathrm{PM}$ reduction may form $\mathrm{SO}_{3}$ in exhaust gas, leading to an increase in PM.

Sulfur content was tested by a third party by passing an x-ray through the sample, where the intensity of the x-ray fluorescence was measured. Figure 6-5 illustrates the level of sulfur in the tested fuels. ASTM D 975 standards call for a maximum sulfur content of $0.50 \%$ by weight, met by all fuels tested [56]. CARB regulations are 500 parts per million, or $0.05 \%$ weight, well above the measured value of $0.017 \%$ weight. Little variance is seen between local fuels, and again Mt. Morris Citgo is the lowest of the three at $0.038 \%$ weight.

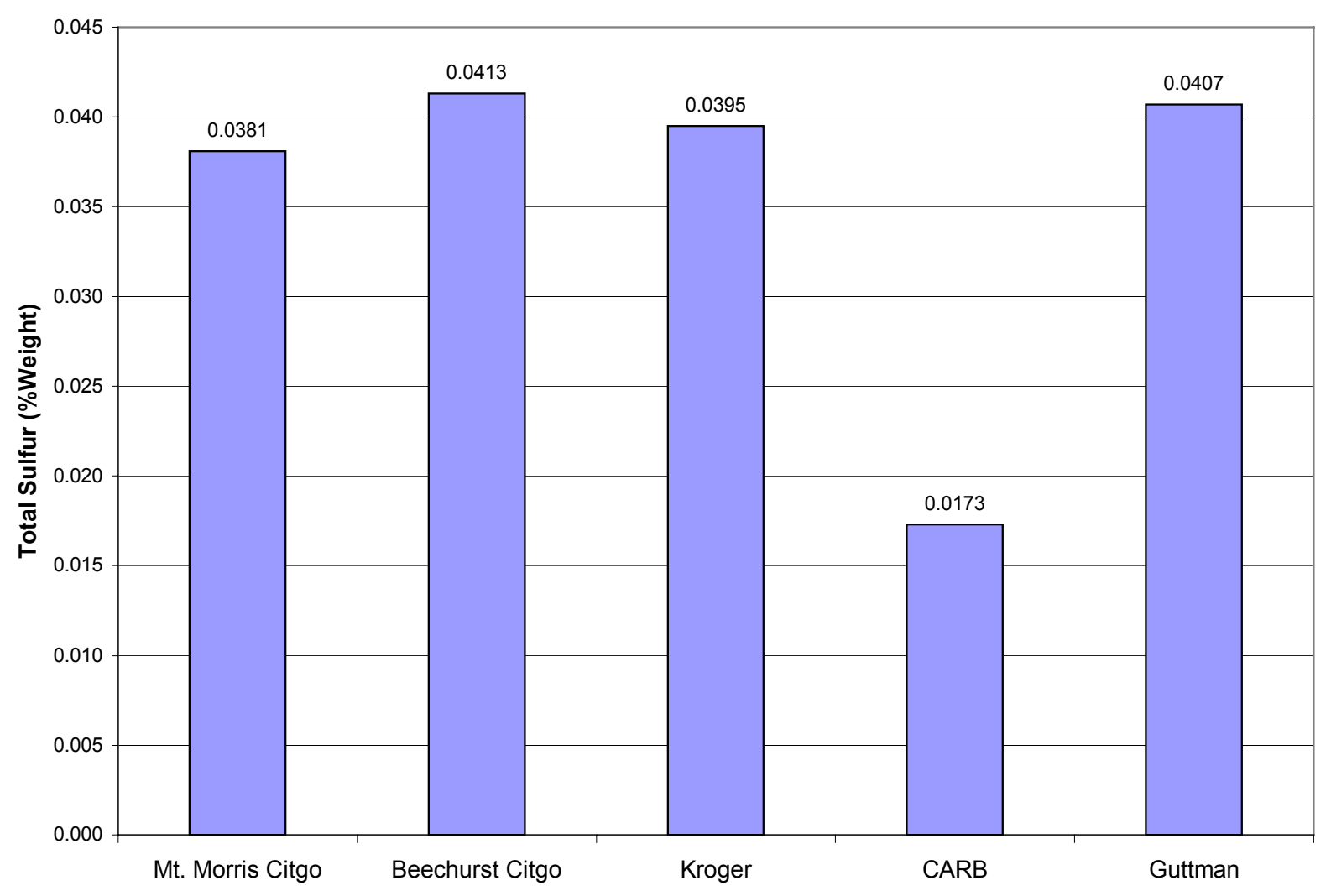

Figure 6-5: Total Sulfur Content in of Fuels Tested 


\subsubsection{Distillation Rate}

The process of distillation occurs in aqueous fuels when hot oil is pumped into a column and the petroleum with lower boiling points will rise to the top of the column and the products with higher boiling points will travel to the lower section of the column [56]. Figure 6-6 displays the distillation temperatures of individual fuels from $5 \%$ to $95 \%$ recovery rates. The minimum distillation $90 \%$ recovery temperature for No. 2 diesel is $539.6^{\circ} \mathrm{F}$, and the maximum $90 \%$ recovery distillation temperature is $640.4^{\circ} \mathrm{F}$. The $90 \%$ recovery temperatures for the fuels analyzed range between $588^{\circ} \mathrm{F}$ and $627^{\circ} \mathrm{F}$. High T90 and T95 temperatures typically indicate high PM levels, and are often used as PM indicators. Lower temperatures at low distillation recovery rates indicates a lower boiling point, which will decrease the ignition delay. CARB fuel had a low temperature at low distillation recovery, and the highest temperature at the 95\% distillation recovery. Beechurst Citgo had the opposite trend, and the Mt. Morris and Guttman fuels had similar distillation trends, with lower temperatures over the distillation curve.

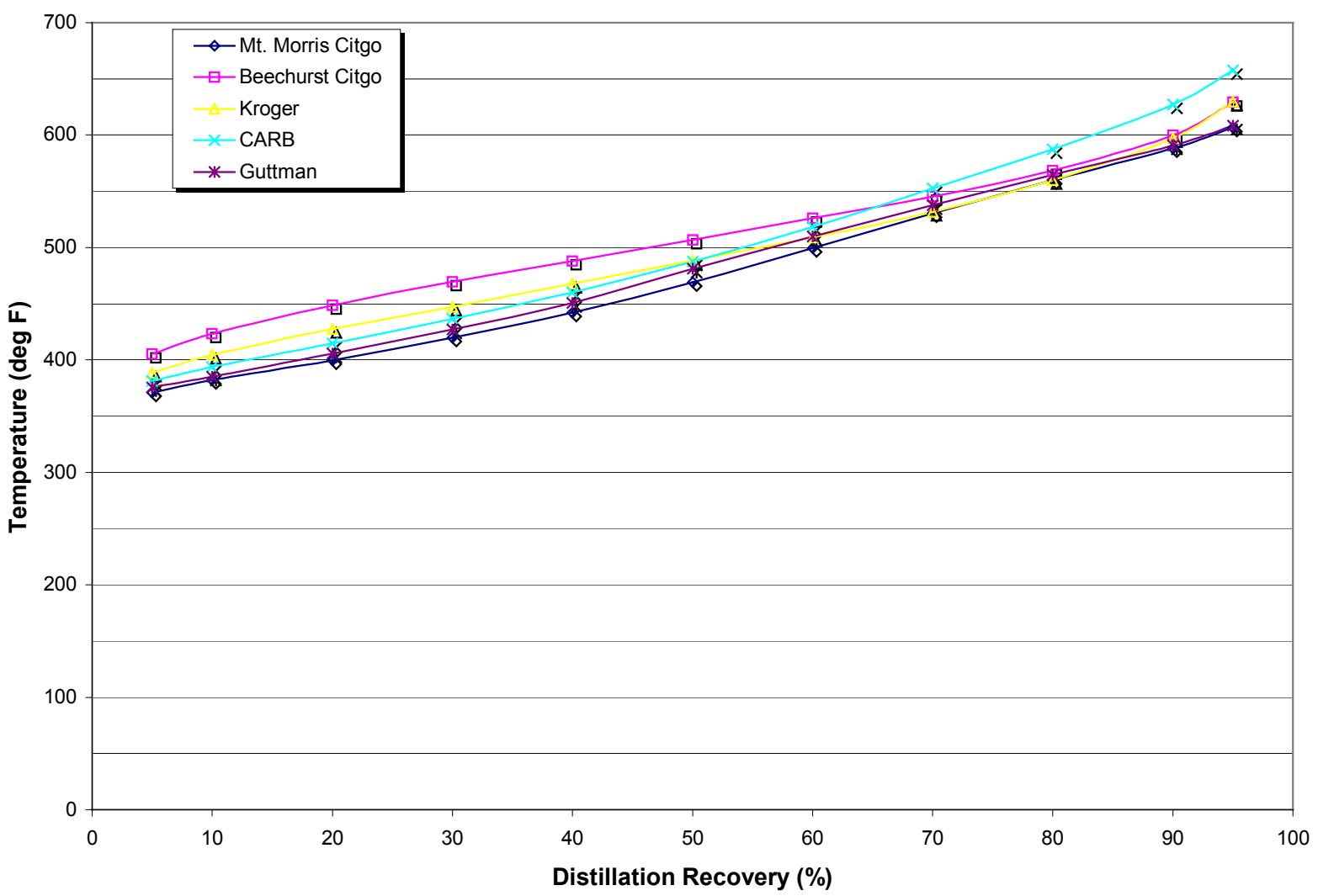

Figure 6-6: Temperature for Multiple Distillation Recovery Points of Fuels Tested 


\subsubsection{Flash Point}

The flash point of a fluid is a measurement of the safety in handling and use of a fuel and is not directly related to performance or emissions in a direct injection CI engine. Flash point was tested by a third party by stirring and heating a sample in a closed cup. The lid was removed and an ignition source was moved over the opening of the cup. The flash point was the lowest temperature where ignition occurs at the introduction of the ignition source [56]. The ASTM D 975 requirement for flash point is a minimum of $125.6^{\circ} \mathrm{F}$ for No. 2 diesel. The fuels tested all met this requirement, the lowest flash point being $144^{\circ} \mathrm{F}$ in Mt. Morris Citgo.

\subsubsection{Effects of Fuel Properties on Performance and Emissions}

A diesel engine was exercised on the generated SAB2BM route that the engine operated on during in-use testing. The engine was mapped only once on Beechurst Citgo fuel. The cycle was repeated three times for each fuel type, following a complete fuel system flushing. It is noted the engine of focus was a randomly selected diesel engine and may not have represented all engine emission trends, nor did the control scheme used by one engine manufacturer represent the control scheme of another. The results of this study are intended to examine the range or variability that may be seen during in-use testing due to factors including fuel quality, not the ability or disability of an individual fuel to meet levels of emission on this engine.

\subsubsection{Fuel Property Emissions Variance}

Figure 6-7 through Figure 6-9 are graphical comparisons of emissions, power, and fuel consumption for the five fuels tested. Data presented in this section are from the laboratory system only. All regulated emissions $\left(\mathrm{HC}, \mathrm{CO}, \mathrm{NO}_{x}, \mathrm{PM}\right), \mathrm{CO}_{2}$, and fuel consumption are given in an attempt to elucidate information from this study. Bars on the data sets signify one standard deviation above and below the average of the three on-road simulated cycles. Average emissions and variation seen are displayed in Table 6-2.

\subsection{Fuel Specific Carbon-Oxide Emissions}

Carbon monoxide varied from $0.751 \mathrm{~g} / \mathrm{Bhp}-\mathrm{Hr}$ for Mt. Morris Citgo to $0.975 \mathrm{~g} / \mathrm{Bhp}-\mathrm{Hr}$ for CARB fuel. CO emissions are generally low for a diesel engine, and all were below the 15.5 $\mathrm{g} / \mathrm{Bhp}-\mathrm{Hr}$ legislation for the FTP cycle. A variation of $24 \%$ existed from the lowest and highest recorded fuel.

$\mathrm{CO}_{2}$ emissions ranged from $580 \mathrm{~g} / \mathrm{Bhp}-\mathrm{Hr}$ for Guttman fuel to $596 \mathrm{~g} / \mathrm{Bhp}-\mathrm{Hr}$ for Kroger diesel fuel. There existed little variation in $\mathrm{CO}_{2}$ emission in the SAB2BM test cycles when fuel 
was varied, only $3.4 \%$ as displayed in Table $6-2$.

Table 6-2: Integrated Results and Variation Analysis of Fuel Type Experiment for Sample Diesel Engine on SAB2BM Dynamometer Cycle

\begin{tabular}{|r|c|c|c|c|c|}
\cline { 2 - 6 } Fuel Type: & $\begin{array}{c}\text { Beechurst } \\
\text { Citgo }\end{array}$ & $\begin{array}{c}\text { Mt. Morris } \\
\text { Citgo }\end{array}$ & Kroger & CARB & Guttman \\
\hline HC (g/Bhp-Hr) & $\mathbf{0 . 1 6 7}$ & $\mathbf{0 . 1 7 1}$ & $\mathbf{0 . 1 8 4}$ & $\mathbf{0 . 1 8 4}$ & $\mathbf{0 . 1 6 2}$ \\
\cline { 2 - 6 } Standard Deviation & 0.008 & 0.010 & 0.004 & 0.009 & 0.004 \\
\hline CO (g/Bhp-Hr) & $\mathbf{0 . 9 4 4}$ & $\mathbf{0 . 7 5 1}$ & $\mathbf{0 . 9 2 1}$ & $\mathbf{0 . 9 7 6}$ & $\mathbf{0 . 7 4 4}$ \\
\cline { 2 - 6 } Standard Deviation & 0.012 & 0.009 & 0.020 & 0.009 & 0.004 \\
\hline CO $_{\mathbf{2}}$ (g/Bhp-Hr) & $\mathbf{5 9 6 . 1}$ & $\mathbf{5 8 2 . 6}$ & $\mathbf{5 9 6 . 0}$ & $\mathbf{5 8 9 . 8}$ & $\mathbf{5 8 0 . 8}$ \\
\cline { 2 - 6 } Standard Deviation & 1.601 & 0.331 & 0.955 & 1.730 & 3.581 \\
\hline NO (g/Bhp-Hr) & $\mathbf{4 . 1 8 1}$ & $\mathbf{3 . 8 9 4}$ & $\mathbf{4 . 1 9 9}$ & $\mathbf{3 . 9 5 2}$ & $\mathbf{3 . 8 8 0}$ \\
\cline { 2 - 6 } Standard Deviation & 0.038 & 0.041 & 0.081 & 0.008 & 0.030 \\
\hline PM (g/Bhp-Hr) & $\mathbf{0 . 0 5 2}$ & $\mathbf{0 . 0 4 4}$ & $\mathbf{0 . 0 5 0}$ & $\mathbf{0 . 0 4 2}$ & $\mathbf{0 . 0 4 0}$ \\
\cline { 2 - 6 } Standard Deviation & 0.002 & 0.002 & 0.002 & 0.000 & 0.001 \\
\hline Work (Bhp-Hr) & $\mathbf{3 5 . 5 0 3}$ & $\mathbf{3 5 . 4 7 0}$ & $\mathbf{3 5 . 5 1 3}$ & $\mathbf{3 5 . 5 0 7}$ & $\mathbf{3 5 . 4 7 3}$ \\
\cline { 2 - 6 } Standard Deviation & 0.021 & 0.017 & 0.025 & 0.050 & 0.012 \\
\hline BSFC (lb/Bhp-Hr) & $\mathbf{0 . 4 0 6}$ & $\mathbf{0 . 4 1 7}$ & $\mathbf{0 . 4 0 7}$ & $\mathbf{0 . 4 0 6}$ & $\mathbf{0 . 4 1 2}$ \\
\cline { 2 - 6 } Standard Deviation & 0.001 & 0.001 & 0.001 & 0.001 & 0.002 \\
\hline Fuel Consumption (lb) & $\mathbf{1 4 . 4 3 7}$ & $\mathbf{1 4 . 7 9 0}$ & $\mathbf{1 4 . 4 6 7}$ & $\mathbf{1 4 . 4 2 3}$ & $\mathbf{1 4 . 6 0 3}$ \\
\cline { 2 - 6 } & 0.012 & 0.030 & 0.035 & 0.021 & 0.064 \\
\hline Standard Deviation & & & & \\
\hline
\end{tabular}

Variation Analysis

\begin{tabular}{|r|c|c||c|c|}
\cline { 2 - 5 } \multicolumn{1}{c|}{} & $\begin{array}{c}\text { Average } \\
\text { Emissions }\end{array}$ & $\begin{array}{c}\text { Standard } \\
\text { Deviation }\end{array}$ & $\begin{array}{c}\text { Coefficient of } \\
\text { Variation (\%) }\end{array}$ & $\begin{array}{c}\text { Min-Max (\%) } \\
\text { Difference }\end{array}$ \\
\hline HC (g/Bhp-Hr) & 0.173 & 0.011 & 6.41 & 18.7 \\
\hline CO $_{\mathbf{2}}$ (g/Bhp-Hr) & 589.1 & 6.893 & 11.91 & 24.6 \\
\hline NO $_{\mathbf{x}}$ (g/Bhp-Hr) & 4.021 & 0.150 & 3.74 & 3.4 \\
\hline PM (g/Bhp-Hr) & 0.046 & 0.005 & 10.72 & 10.1 \\
\hline Work (Bhp-Hr) & 35.493 & 0.030 & 0.09 & 26.1 \\
\hline BSFC (lb/Bhp-Hr) & 0.410 & 0.004 & 1.09 & 0.3 \\
\hline Fuel Consumption (lb) & 14.544 & 0.147 & 1.01 & 3.1 \\
\hline
\end{tabular}




\subsection{Fuel Specific HC Emissions}

$\mathrm{HC}$ emissions certifications for the FTP cycle were set to a level of $0.5 \mathrm{~g} / \mathrm{Bhp}-\mathrm{Hr}$ for 2004 and $0.14 \mathrm{~g} / \mathrm{Bhp}-\mathrm{Hr}$ in 2007. Legislation currently lies at $1.3 \mathrm{~g} / \mathrm{Bhp}-\mathrm{Hr}$ for the FTP cycle. Hydrocarbons generally are not a major concern for diesel engines. The minimum-to-maximum variation of $\mathrm{HC}$ was $18 \%$. An examination of Figure 6-7 and Table 6-2 shows a large test-to-test variability, likely a result of ambient concentrations during testing. With increasing restrictions, the fuel quality may play a role in reducing $\mathrm{HC}$ emissions.

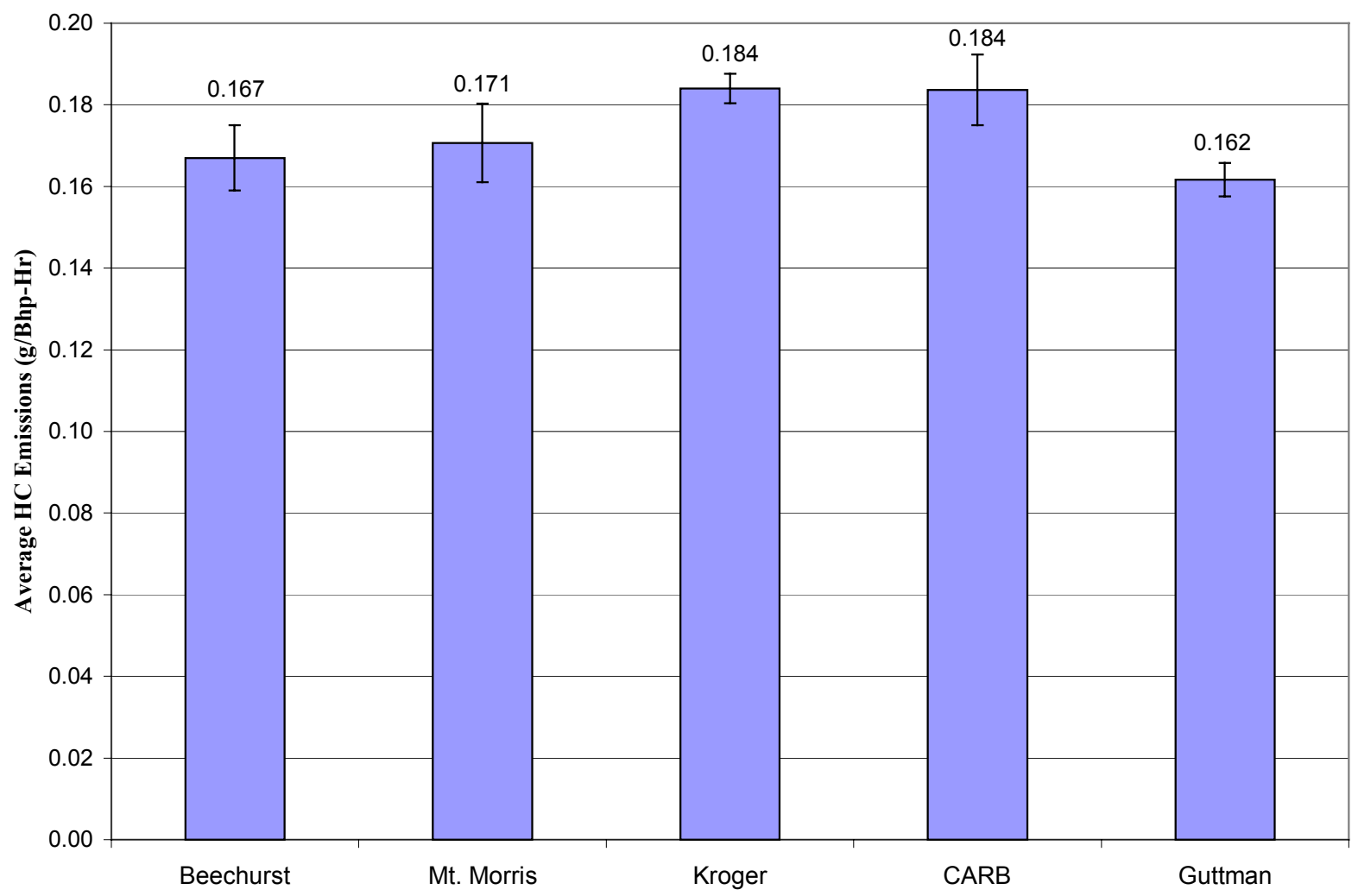

Figure 6-7 Effects of Fuel on Sample Diesel Engine Average Brake-specific HC Emissions for SAB2BM Cycle on WVU DC Dynamometer 


\subsection{Fuel Specific PM Emissions}

PM emissions ranged from $0.040 \mathrm{~g} / \mathrm{Bhp}-\mathrm{Hr}$ for CARB to $0.052 \mathrm{~g} / \mathrm{Bhp}-\mathrm{Hr}$ for Beechurst Citgo fuel. The 2004 standards call for $0.1 \mathrm{~g} / \mathrm{Bhp}-\mathrm{Hr}$, and 2007 0.01g/Bhp-Hr of PM for the FTP cycle. As displayed in Table 6-2, a significant PM variation of 26\% existed between fuels.

Distillation rates, specific gravity, and cetane number may all have contributed to the variance of PM emission, and attempts to quantify the trends of these parameters is presented in Section

\subsubsection{2.}

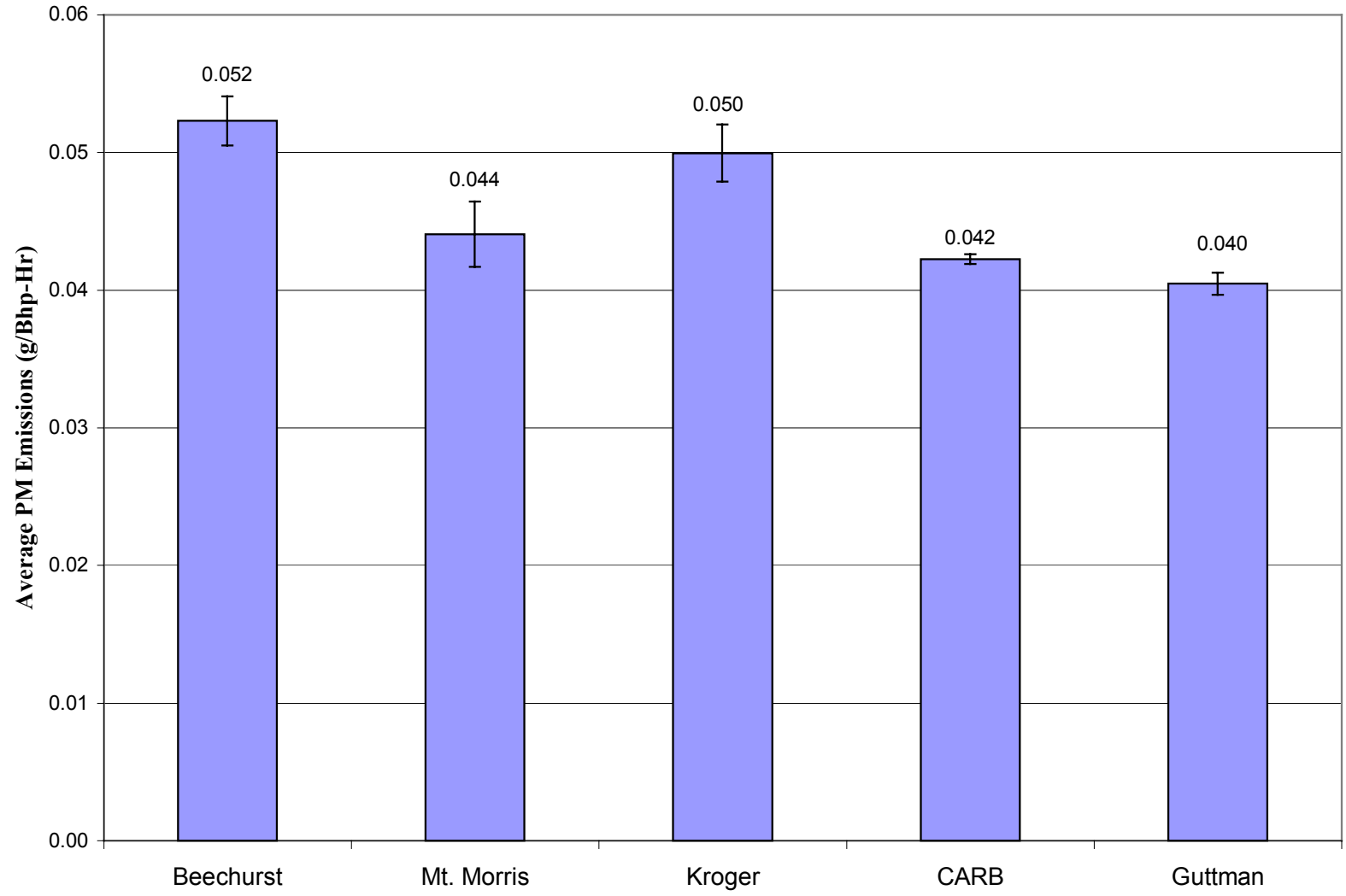

Figure 6-8: Effects of Fuel on Sample Diesel Engine Average Brake-specific PM Emissions for Simulated SAB2BM Cycle on WVU DC Dynamometer 


\subsection{Fuel Specific $N O_{x}$ Emissions}

$\mathrm{NO}_{\mathrm{x}}$ emissions are of major concern in current and future emissions standards, and Figure 6-9 displays the $\mathrm{NO}_{\mathrm{x}}$ produced for the SAB2BM cycle for each fuel on the sample diesel engine. Varying from $3.880 \mathrm{~g} / \mathrm{Bhp}-\mathrm{Hr}$ for Guttman fuel to 4.199 for Kroger fuel, a 10.1\% difference was seen from the minimum and maximum emitting fuels. Since $\mathrm{NO}_{\mathrm{x}}$ is to be restricted so tightly (0.2 g/Bhp-Hr in 2007 for the FTP cycle), a 10\% variation could be significant in the future.

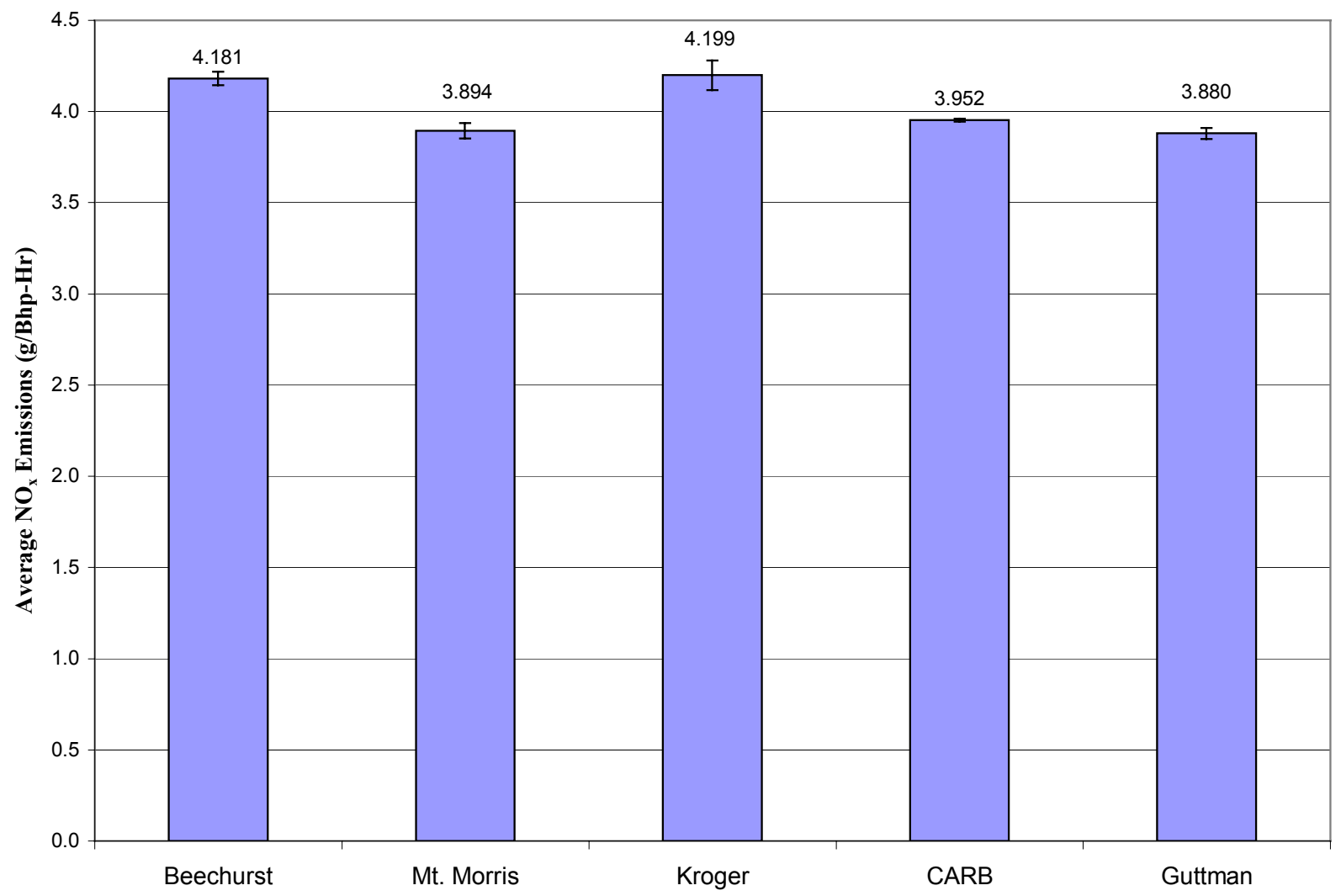

Figure 6-9: Effects of Fuel on Sample Diesel Engine Average Brake-specific NO $_{x}$ Emissions for SAB2BM Cycle on WVU DC Dynamometer

\subsection{Fuel Specific Work Output}

The work output form the engine varied only by $0.3 \%$ from fuel-to-fuel on the cycle.

This was seemingly insignificant, but the fuel consumption varies by $3 \%$. Considering the immense cost of fuel for large fleets of trucks, a 3\% savings in fuel economy can have a significant impact on the operational costs of trucking. There existed a variation in the measurement system itself, and further investigation with a larger test matrix may be required for a complete analysis 


\subsubsection{Relationships Between Fuel Property and Emissions}

Previous efforts have proven it difficult to draw direct relationships between certain fuel characteristics and emissions or performance, as variables influenced the physical and chemical processes which govern combustion. Though trends are apparent for specific engines studied, they often differ from engines with different mechanical components or control strategies. For example, an engine with distributor type fuel injection pumps have a higher sensitivity to fuel property variance than the in-line pump found in most HDDEs [35]. Many of the fuel parameters were inter-related, making it difficult to alter only one fuel characteristic for study. The objective of this analysis was to quantify the variation that fuel may have on performance and emissions, and all conclusions drawn on fuel characteristics and their effects were made in an attempt to gain understanding on the sources of variation.

Studies have suggested that aromatic content may have some control over the chemistry of combustion, thus influencing the flame temperatures [43]. Aromatics can be separated into two categories, monocyclic and polycyclic (PAH). It has been found that PAH compounds may reduce $\mathrm{HC}, \mathrm{NO}_{\mathrm{x}}$, and $\mathrm{PM}$ emission. Aromatic content also reduces the lower heating value of a fuel, increasing the BSFC of the engine. Figure 6-10 displays a slight increase in $\mathrm{NO}_{\mathrm{x}}$ emission as aromatic content increases. This data was taken during a SAB2BM engine dynamometer cycle on a sample diesel engine. The slope of curve fit equation, like the one seen in Figure 6-10, yield the strength of dependence of the measured subject of interest on the control variable, and the $\mathrm{R}^{2}$ value yields a measure of the accuracy of the linear fit to the data set, with an $\mathrm{R}^{2}$ value of 1 being perfect. The aromatic content was by no means the only variable between the fuels, and other factors may have had significant impact on $\mathrm{NO}_{\mathrm{x}}$ emission. The trend of increasing $\mathrm{NO}_{\mathrm{x}}$ emission with subsequent increases in aromatic content was also seen in most previous works [35,38]. 


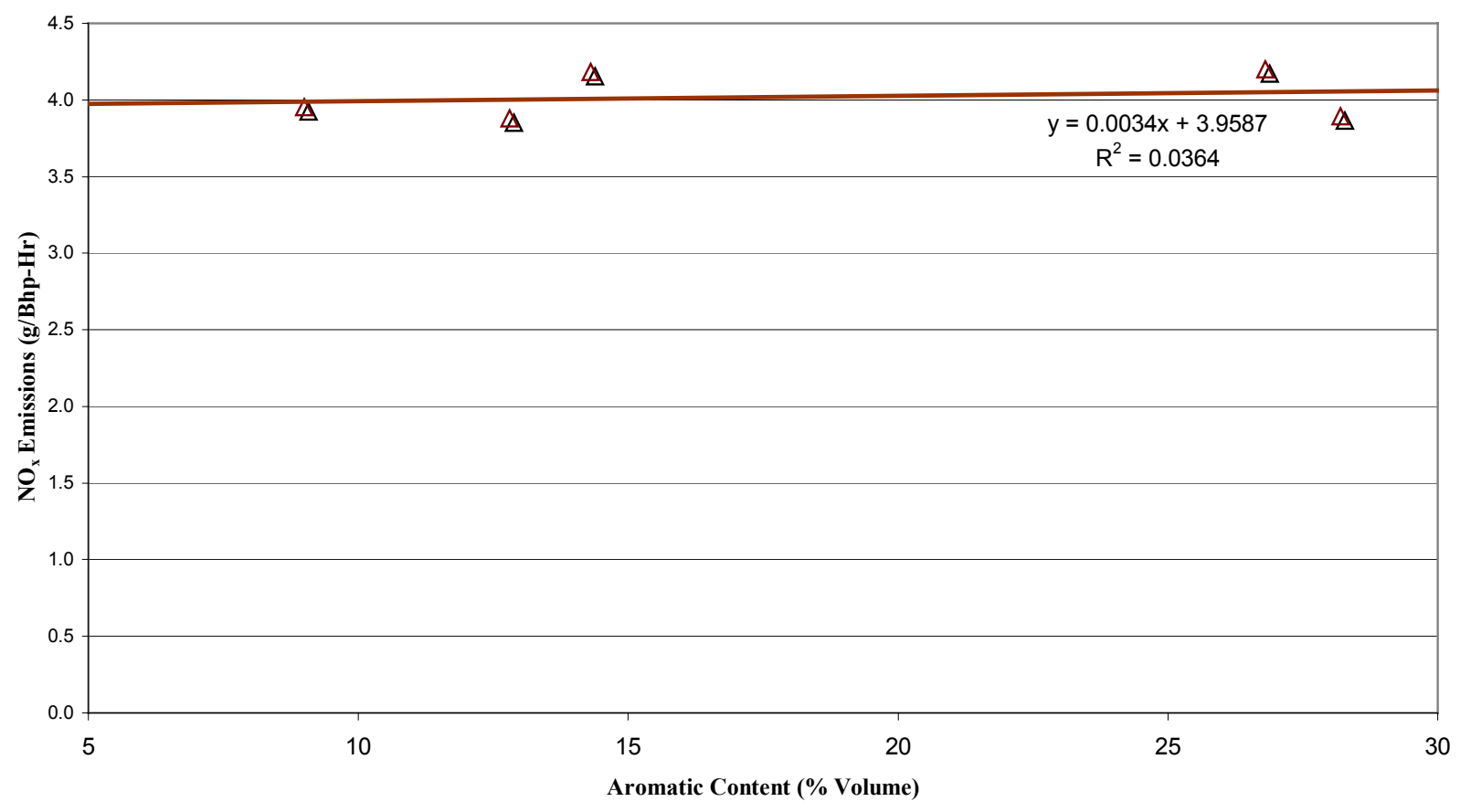

Figure 6-10: Sample Diesel Engine $\mathrm{NO}_{\mathrm{x}}$ Emission as a Function of Aromatic Content for SAB2BM Cycle on WVU DC Dynamometer

A decrease in density may lower the instantaneous mass flow rate of fuel, increasing the injection period [43]. This may result in a reduction in lower heat release rates, and subsequently $\mathrm{NO}_{\mathrm{x}}$ formation rates. High engine speeds and high loads may result in incomplete combustion if the density of the fuel is too low, leading to an increase in $\mathrm{HC}$ and $\mathrm{CO}$ emissions. The fuels analyzed in this study showed a general tend to increase $\mathrm{HC}$ and $\mathrm{CO}$ emissions for the SAB2BM cycle, with little impact on PM emission. $\mathrm{NO}_{\mathrm{x}}$ was reduced with increasing density, as predicted by heat release rate theory. Other studies provide results for $\mathrm{CO}$ and $\mathrm{HC}$, claiming increases with decreasing density, and some studies have shown density is not shown to affect the emissions of the modern diesel engine [56].

Mann [35] found that density was one of the most crucial parameters governing the physical effects of the fuel delivery system. A low density fuel was found to have a lower level of $\mathrm{NO}_{\mathrm{x}}$, even with a high level of control over the fuel delivery system. Mann also found an increase in PM in most cases of increased density. Density was found to be an important fuel quality, as increases in density result in increased volumetric energy content, producing more power per volume of fuel when compared to a low density fuel, thus increases in fuel economy. 


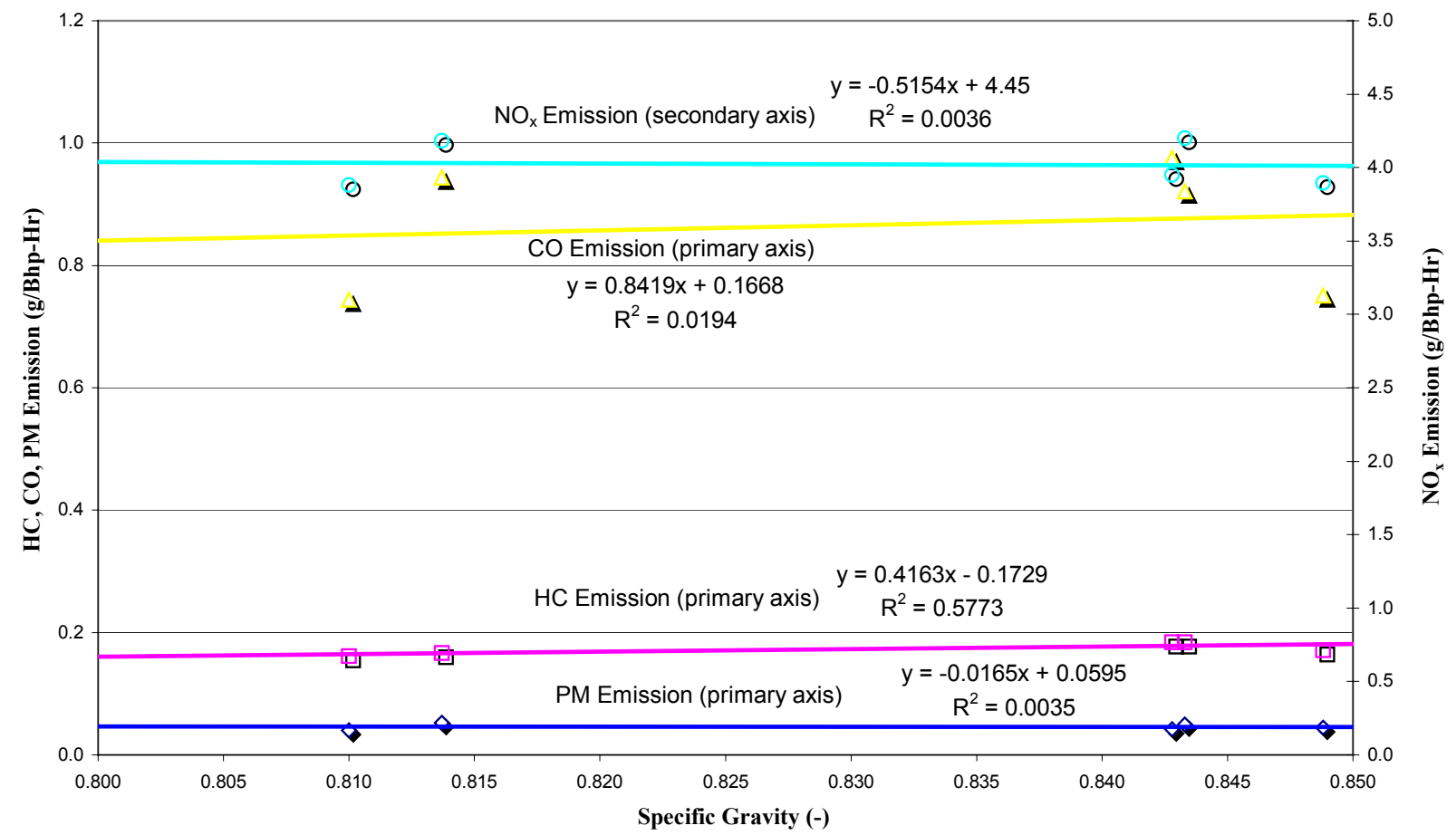

Figure 6-11: Sample Diesel Engine CO, HC, and PM Emission as a Function of Specific Gravity for SAB2BM Cycle on WVU DC Dynamometer

Cetane number is generally accepted as the largest influence of the combustion quality of a fuel [43]. The combustion quality is not a clearly defined value, so for the purpose of discussion it was defined as a combination of the heat release rate of a fuel once combustion events begin, the ignition delay of a fuel, and the combustion roughness of a fuel undergoing burn. A lower cetane number is known to increase the ignition delay of a fuel [57]. A decrease in cetane number also increases combustion roughness, decreasing the rate of heat release of the fuel, which may lead to a decrease in engine power with an improperly timed peak cylinder pressure [58]. Low cetane number may also lead to a spike in pressure during the onset of ignition, which contributes to roughness, decreasing the life expectancy of an engine.

Studies have returned varying amounts cetane influence on emissions [43]. It has been shown $\mathrm{HC}$ and $\mathrm{CO}$ emission reduction occurs with an increase in cetane number, but as engine technology improves these effects are decreasing, or non-existent. $\mathrm{NO}_{\mathrm{x}}$ reduction was seen in nearly all increases in cetane, but the effects of a cetane number which is over 60 have a diminishing $\mathrm{NO}_{\mathrm{x}}$ reduction effects. The fuel study analysis performed yielded results matching 
previous studies [35,38], as displayed in Figure 6-12, with an increased cetane decreasing $\mathrm{NO}_{\mathrm{x}}$, $\mathrm{CO}$, and $\mathrm{HC}$ emissions, and little effect on PM. Studies regarding PM have shown to either increase, decrease, or have no change with increases in cetane number.

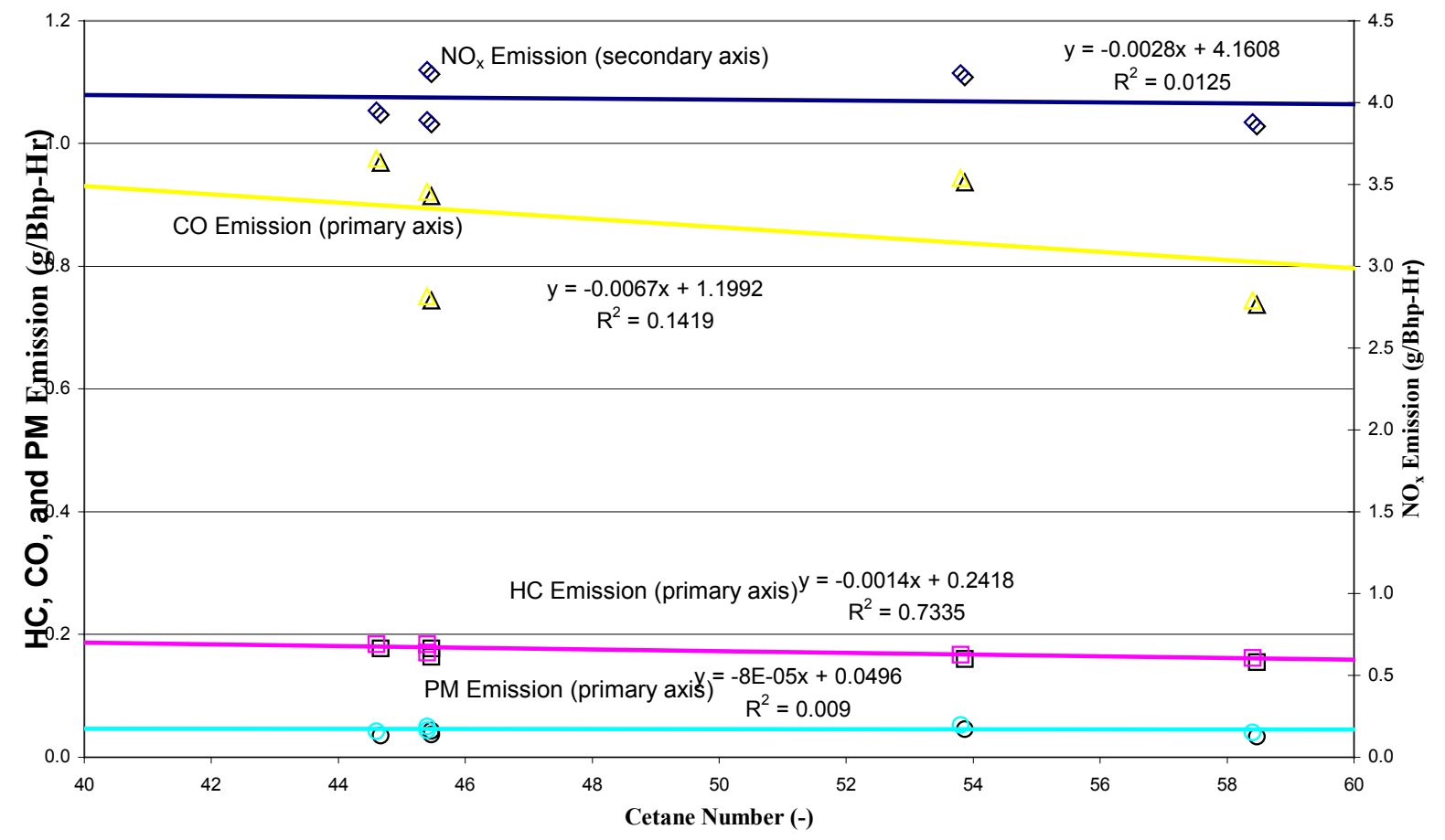

Figure 6-12: Sample Diesel Engine $\mathrm{HC}, \mathrm{CO}, \mathrm{PM}$, and $\mathrm{NO}_{\mathrm{x}}$ Emissions as a Function of Cetane Number for SAB2BM Cycle on WVU DC Dynamometer

Sulfur content is known to directly effect sulfate content in PM emissions, but the portion of sulfate content in PM emissions is low and often insignificant [37,43]. Increases in sulfur had only slight increases in PM for the fuel analysis study, but the tight legislation of future PM emissions mat lead to an increased role of sulfur in PM emissions.

There are varying reports of distillation effects on engine emissions [43]. Most studies focused on T50, T90, and T95 distillation points (T50 signifies Temperature at 50 percent recovery, and so on). The heavier fuel molecules are more difficult to burn, and may increase $\mathrm{HC}$ and PM emissions. The trends noticed in the data collected during the fuel variance study are displayed in Figure 6-13. The increase in T95 recovery temperature increased HC emissions, with little impact on PM emission. It is also noted an increase in T95 distillation increased $\mathrm{NO}_{\mathrm{x}}$ emission. It follows a fuel with low upper boiling points will evaporate more rapidly in a cylinder, aiding in the rate of combustion. 


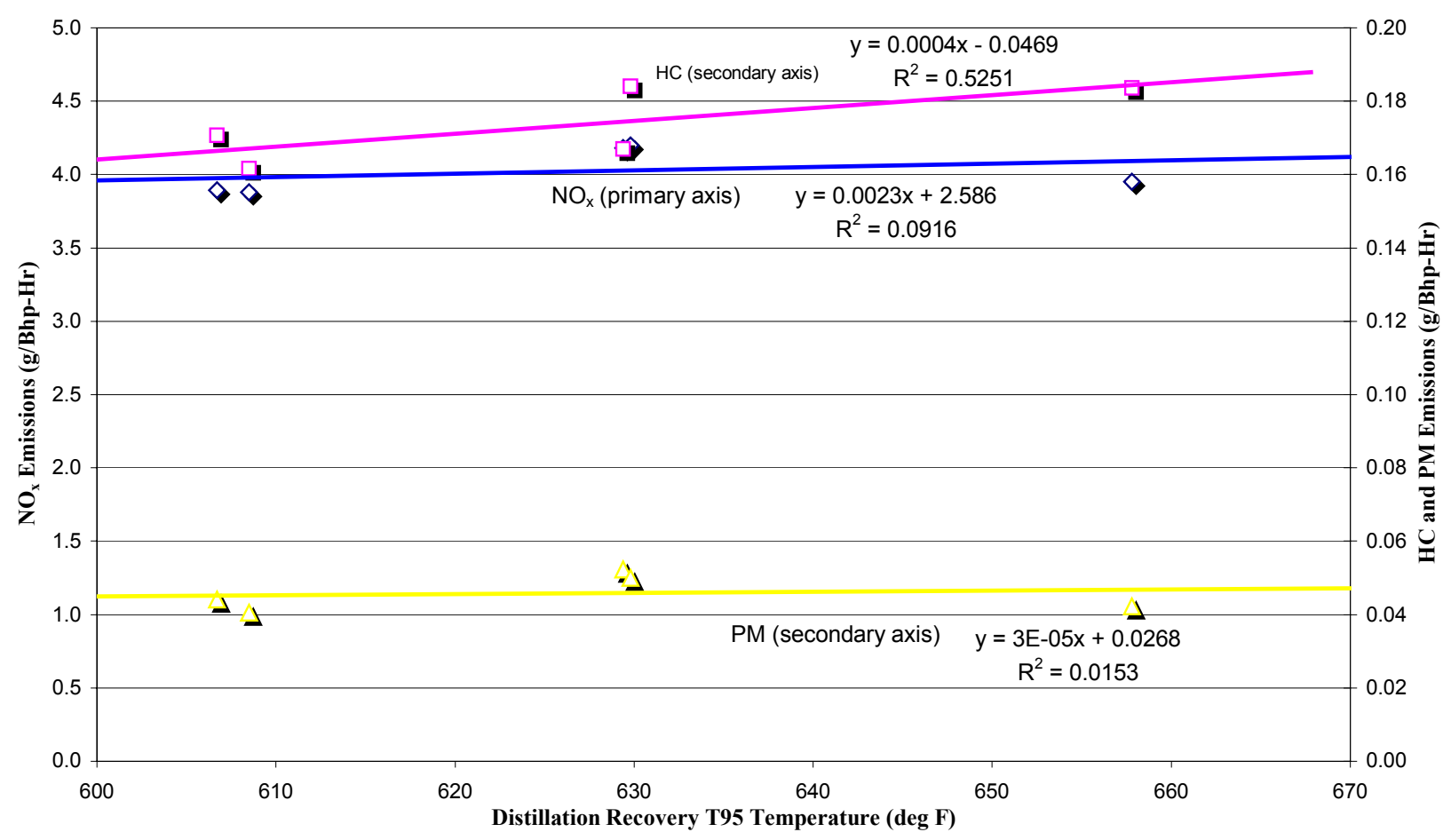

Figure 6-13: Sample Diesel Engine $\mathrm{HC}_{\text {, }} \mathrm{NO}_{\mathrm{x}}$, and PM Emissions as a Function of T95 Distillation for SAB2BM Cycle on WVU DC Dynamometer

\subsubsection{Effects of Engine Operating Conditions on Performance and Emissions}

In order to qualify the reproduction of an in-use route, the effects of ambient conditions and engine operating parameters were taken into account. It is the standard practice to control fuel temperature, intake air temperature, and engine restrictions in the intake and exhaust during emissions testing [47]. In typical testing conditions fuel temperature is to be held constant at $95^{\circ} \mathrm{F}$, intake air is to stay in the range of $68^{\circ} \mathrm{F}$ to $86^{\circ} \mathrm{F}$, intercooler outlet temperature is set at 120 ${ }^{\circ} \mathrm{F}$, and engine restrictions are set according to manufacturer specifications.

The conditions described above were varied to their minimum and maximum values achievable at steady state, while insuring safe engine operation. Table 6-3 displays the set range of those conditions, which may have deviated due to transients in the SAB2BM test. Fuel temperature was controlled by the existing apparatus described in the EERC experimental equipment section of this paper, along with a secondary water-to-fuel heat exchanger placed on the primary fuel inlet line.

Intake air temperature was heated using a heat exchanger, while low temperature was 
achievable using ambient winter air conditions. Manifold air inlet temperature was controlled by altering intercooler outlet temperature. This was accomplished by adjusting the water temperature to the liquid-to-air intercooler. Intake and exhaust pressures were set at maximum power operating conditions using throttling plates.

Table 6-3: Operating Condition Study Test Ranges Set Points

\begin{tabular}{|c|c|c|}
\hline Property & Min & Max \\
\hline Fuel Temperature (deg F) & 55 & 140 \\
\hline Pre-Turbo Air Temperature (deg F) & 55 & 120 \\
\hline Intercooler Temperature (deg F) & 42 & 97 \\
\hline Intake Depression (in $\mathrm{H}_{2} 0$ ) & 7.0 & 29.3 \\
\hline Exhaust Restriction (in $\mathrm{H}_{2} 0$ ) & 11.5 & 51.5 \\
\hline
\end{tabular}

Varying air temperatures at different stages of the engine had different effects on engine output. Table 6-4 displays the average air mass into the engine, the average intake air temperature and average manifold air temperature over the SAB2BM route for the condition studies relating to air temperature control.

Varying pre-turbo intake air temperature had an influence on the density of air and temperature of air entering the intercooler and the cylinder. The air still had to travel through the intercooler which was set at normal conditions for pre-turbo air control tests, bringing the average manifold air temperature closer to normal operating temperatures, 87.8 and $84.2^{\circ} \mathrm{F}$.

The intercooler temperature study altered the temperature of the air entering the manifold, and had no influence on the pre-turbocharger intake air temperature. It is apparent from the average intake air mass that control of air temperature has an impact on the amount of air which enters the cylinder, which alters the efficiency of the engine as well as the chemical combustion processes which govern power and emissions output. 
Table 6-4: Average Measured Air Mass, Intake Air Temperature and Manifold Temperature for Operating Condition Study

\begin{tabular}{|r|c|c|c|c|}
\multicolumn{1}{c|}{} & $\begin{array}{c}\text { Hot } \\
\text { Intake }\end{array}$ & $\begin{array}{c}\text { Cold } \\
\text { Intake }\end{array}$ & $\begin{array}{c}\text { Hot } \\
\text { Intercooler }\end{array}$ & $\begin{array}{c}\text { Cold } \\
\text { Intercooler }\end{array}$ \\
\hline Average Intake Air Mass (lb) & 585.6 & 614.5 & 591.8 & 609.8 \\
\hline Average Intake Air Temperature (deg F) & 111.2 & 59.0 & 78.8 & 78.8 \\
\hline Average Manifold Air Temperature (deg F) & 87.8 & 84.2 & 102.2 & 68.0 \\
\hline
\end{tabular}

Each characteristic was integrated over the cycle on a brake-specific mass emission basis. The standard deviation and COV were determined, as displayed in Table 6-5. Significant variation was seen in $\mathrm{HC}$ and $\mathrm{PM}$ emissions. $\mathrm{CO}$ and $\mathrm{NO}_{\mathrm{x}}$ were also significantly effected by the alteration of operating conditions, with over $10 \% \mathrm{COV}$.

The Min-Max column of Table 6-5 is the maximum percent variation of all test cycles. Detailed inspection of particular conditional responses is shown from Figure 6-14 through Figure 6-19, and summary sheets of each condition experiment are available in Appendix D. COV and min-max calculations exclude normal operation results.

Table 6-5: Integrated Results and Variation Analysis of Operating Condition Experiment for Sample Diesel Engine on SAB2BM Dynamometer Cycle

\begin{tabular}{|r|c|c||c|c|}
\cline { 2 - 5 } \multicolumn{1}{c|}{} & $\begin{array}{c}\text { Average } \\
\text { Integrated }\end{array}$ & $\begin{array}{c}\text { Standard } \\
\text { Deviation }\end{array}$ & $\begin{array}{c}\text { COV } \\
\mathbf{( \% )}\end{array}$ & $\begin{array}{c}\text { Min-Max } \\
\mathbf{( \% )}\end{array}$ \\
\hline HC (g/Bhp-Hr) & 0.164 & 0.018 & 11.0 & 26.1 \\
\hline CO (g/Bhp-Hr) & 0.757 & 0.032 & 4.2 & 10.9 \\
\hline CO $_{\mathbf{2}}$ (g/Bhp-Hr) & 574 & 8.357 & 1.5 & 4.4 \\
\hline NO $\mathbf{\text { (g/Bhp-Hr) }}$ & 3.85 & 0.148 & 3.9 & 10.7 \\
\hline PM (g/Bhp-Hr) & 0.0467 & 0.005 & 11.8 & 29.1 \\
\hline Work (Bhp-Hr) & 35.5 & 0.036 & 0.1 & 0.3 \\
\hline BSFC (lb/Bhp-Hr) & 0.418 & 0.005 & 1.1 & 3.1 \\
\hline Fuel Consumption (lb) & 14.8 & 0.168 & 1.1 & 3.1 \\
\hline
\end{tabular}

\subsubsection{Integrated Work}

The integrated work varied from 35.42 Bhp-Hr for low air restriction to $35.53 \mathrm{Bhp}-\mathrm{Hr}$ for cold intake air tests. Temperatures and pressures in the system control the amount of air which enters the cylinder. Less air means less work must be done in the compressions stage, but may lead to more incomplete combustion, a tradeoff in power output. The engine did do less work on the low restriction tests than the high restriction tests, as the pumping efficiency of the engine 
slightly increases. A low total variation existed, $0.3 \%$ from the minimum to maximum values, within the accuracy levels of the equipment. It is noted the integrated work output is the denominator in the calculation of energy specific emissions levels, and influenced these values.

\subsubsection{HC Emissions}

$\mathrm{HC}$ emissions, displayed for all condition experiments in Figure 6-14, varied from 0.136 to $0.184 \mathrm{~g} / \mathrm{Bhp}-\mathrm{Hr}$ in the test matrix, a $26 \%$ min-max variation. The $\mathrm{COV}$ was high, $11 \%$. Seemingly significant contributors to $\mathrm{HC}$ emissions were engine restrictions, intercooler temperature, and intake air temperature. It is noted the reduction of $\mathrm{HC}$ emissions was possible through a process of heating the fluids and restricting the engine.

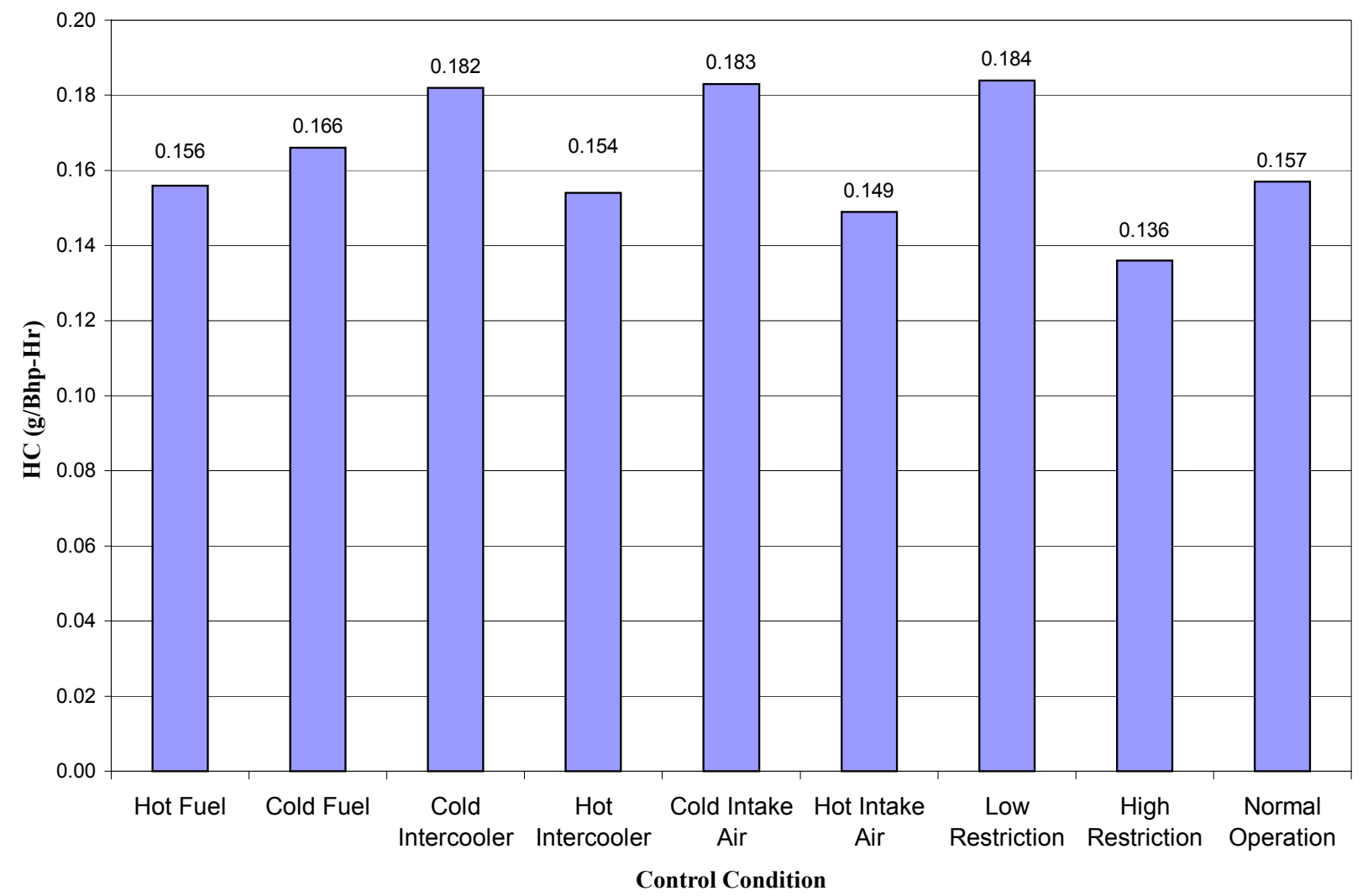

Figure 6-14: Effects of Operating Conditions on Sample Diesel Engine Brake-specific HC Emissions for SAB2BM Cycle on WVU DC Engine Dynamometer 


\subsubsection{CO Emissions}

$\mathrm{CO}$ emissions are shown in Figure 6-15 to vary from 0.713 to $0.8 \mathrm{~g} / \mathrm{Bhp}-\mathrm{Hr}$ for the condition study. A min-max variation of $11 \%$ existed from the lowest and highest recorded condition. The lowest emission of $\mathrm{CO}$ was seen in the Cold intercooler study, and the highest levels in the high restriction study. The variance of the overall study was small, $4.18 \% \mathrm{COV}$. $\mathrm{CO}$ emissions are generally low for a diesel engine, and all were well below the current 15.5 g/Bhp-Hr standards for the FTP cycle. CO emissions are typically dependent on the type of cycle the engine is operating.

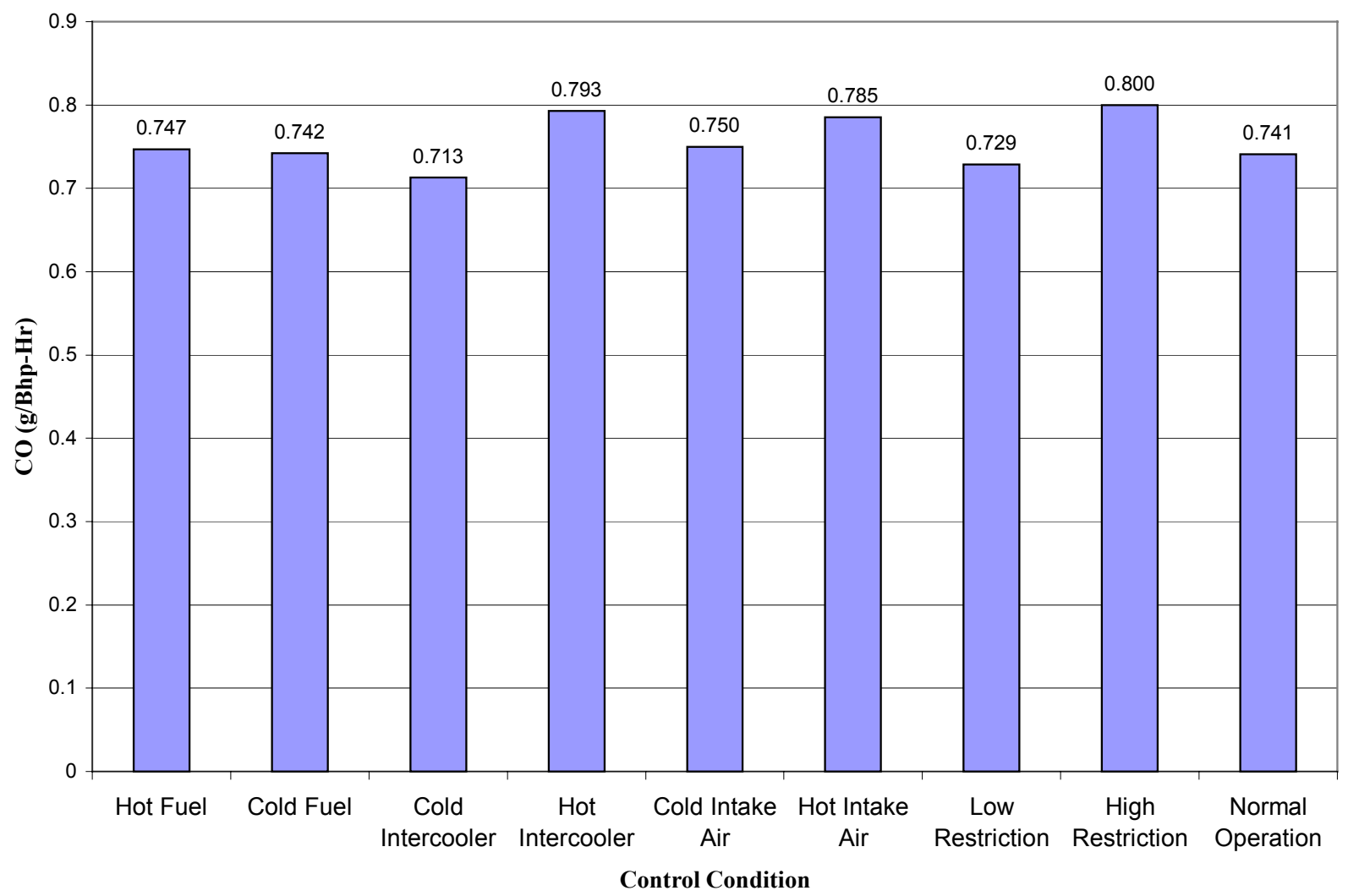

Figure 6-15: Effects Operating Conditions on Sample Diesel Engine Brake-specific CO Emissions for SAB2BM Cycle on WVU DC Engine Dynamometer 


\subsubsection{4 $\mathrm{CO}_{2}$ Emissions}

$\mathrm{CO}_{2}$ emissions, as seen in Figure 6-16, varied from 556 for the cold intercooler to 581 $\mathrm{g} / \mathrm{Bhp}-\mathrm{Hr}$ for high flow restriction in the condition control experiments. There was a min-max variation of $4.4 \%$, with a $\mathrm{COV}$ of $1.45 \% \mathrm{CO}_{2}$ emissions were of little concern for emissions certification at this time, but were used in fuel recovery calculations in both MEMS and EERC systems. $\mathrm{CO}_{2}$ is typically governed by the $\mathrm{C}: \mathrm{H}$ fuel ratio, therefore fuel consumption was able to be inferred from $\mathrm{CO}_{2}$ concentrations when $\mathrm{C}: \mathrm{H}$ is known. The condition tests did not significantly alter the engine $\mathrm{CO}_{2}$ emissions.

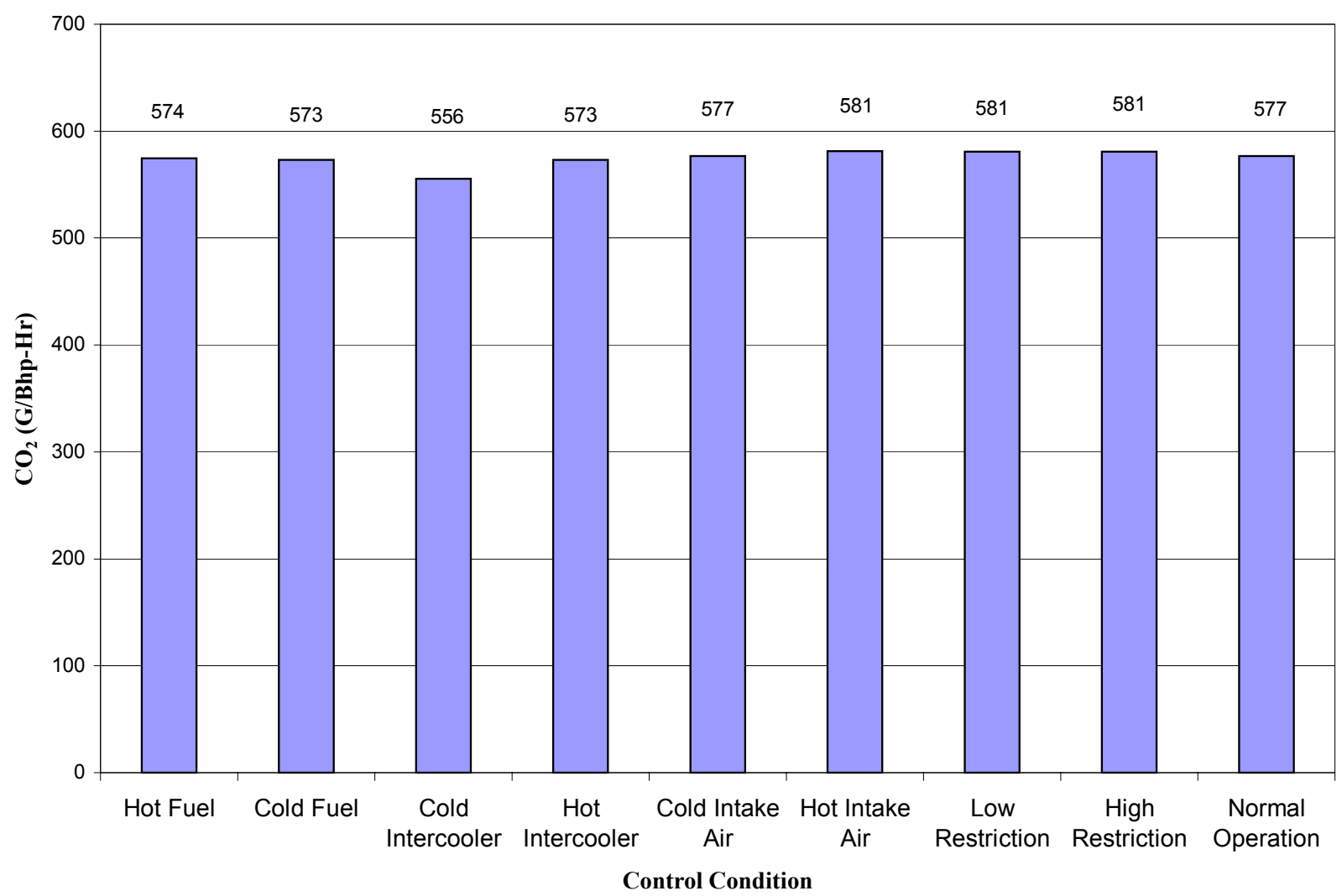

Figure 6-16: Effects of Engine and Ambient Conditions on Brake-specific CO2 Emissions for Simulated Bruceton Mills On-Road Cycle on WVU DC Engine Dynamometer 


\subsubsection{5 $\mathrm{NO}_{\mathrm{x}}$ Emissions}

$\mathrm{NO}_{\mathrm{x}}$ emissions varied from a minimum of 3.713 for the cold intake air to a maximum of $4.159 \mathrm{~g} / \mathrm{Bhp}-\mathrm{Hr}$ for the hot intake air study. This was a $10.7 \% \mathrm{~min}-\mathrm{max}$ variation. The trend of $\mathrm{NO}_{\mathrm{x}}$ production relating to conditions is displayed in Figure 6-17. The variation in $\mathrm{NO}_{\mathrm{x}}$ may have been due to several parameters. The ECU control strategy may have altered injection timing based upon intake air temperature, leading to an increase in $\mathrm{NO}_{\mathrm{x}}$. An increase in $\mathrm{NO}_{\mathrm{x}}$ typically leads to a decrease in PM, which was not the case when Figure 6-18 is analyzed. This does not necessarily disprove the $\mathrm{NO}_{\mathrm{x}}-\mathrm{PM}$ tradeoff is occurring, since other factors such as performance related issues may have been present, altering the combustion characteristics and consequently the chemical reactions governing the creation of $\mathrm{NO}_{\mathrm{x}}$ and $\mathrm{PM}$. It was concluded that operating conditions do alter emissions, be it through ECU or chemical/combustion properties.

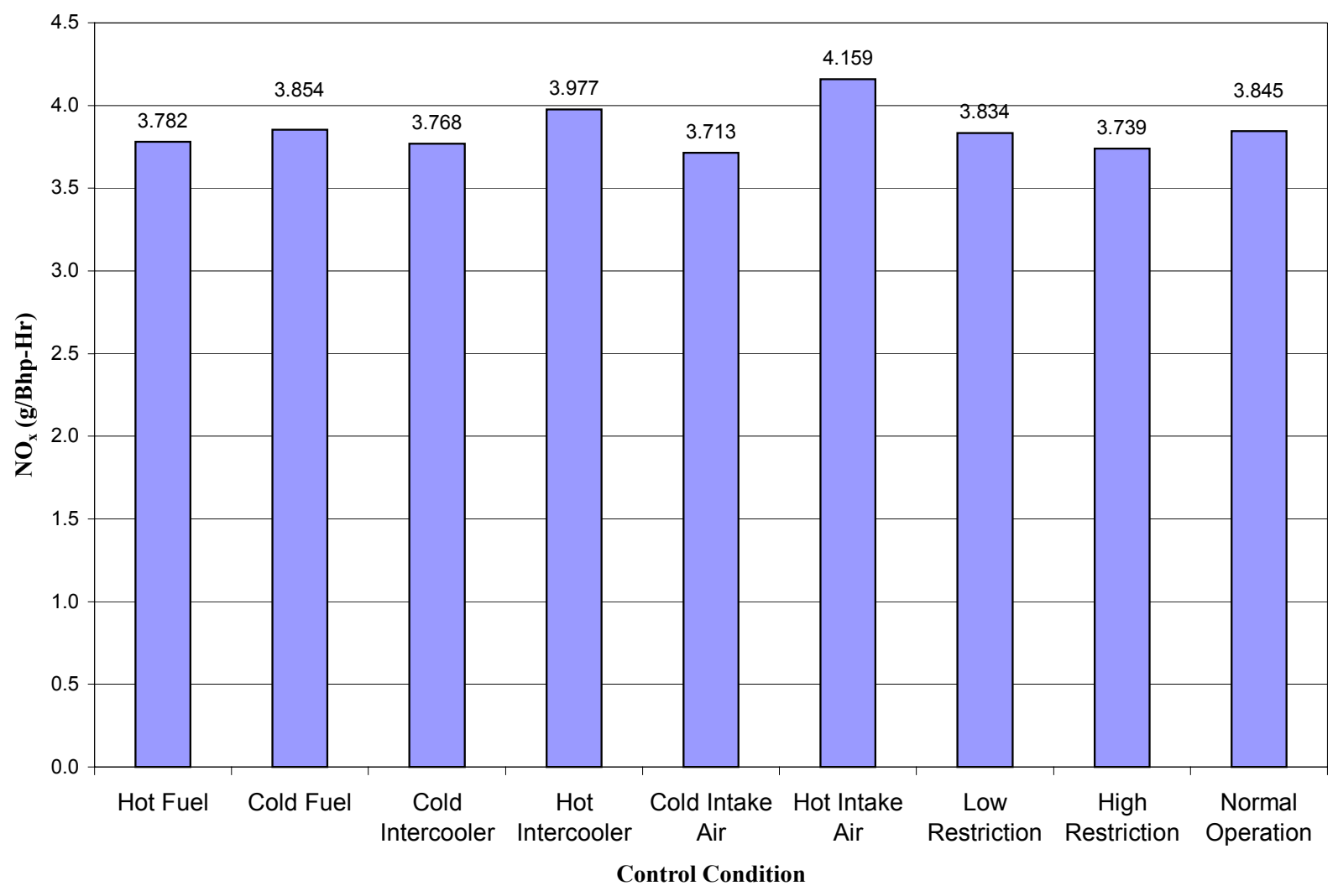

Figure 6-17: Effects of Engine and Ambient Conditions on Brake-specific NOx Emissions for Simulated Bruceton Mills On-Road Cycle on WVU DC Engine Dynamometer 


\subsubsection{PM Emissions}

The PM emission results displayed in Figure 6-18 varied from 0.041 to $0.058 \mathrm{~g} / \mathrm{Bhp}-\mathrm{Hr}$ for conditions other than normal operation, a 29\% min-max variation. The COV for PM was $11.78 \%$. It is noted that each study led to an increase in PM from the baseline emission test. Conclusions on this phenomena are not easily drawn. The hot intercooler temperature test was higher in emission than the low intercooler temperature, yet the cold intake air temperature test was significantly higher than the hot intake air temperature test.

It is noted the PM filter temperature reached high levels during some tests, and the addition of secondary dilution air may increase measurement accuracy. Also the temperature and humidity of the PM filter conditioning room influences the filter weighing. Operator error in calibration and filter handling can also generate variation in microbalance readings. The variability in the PM sampling system may have lead to the variability of the data, and warrants more work before conclusions are drawn.

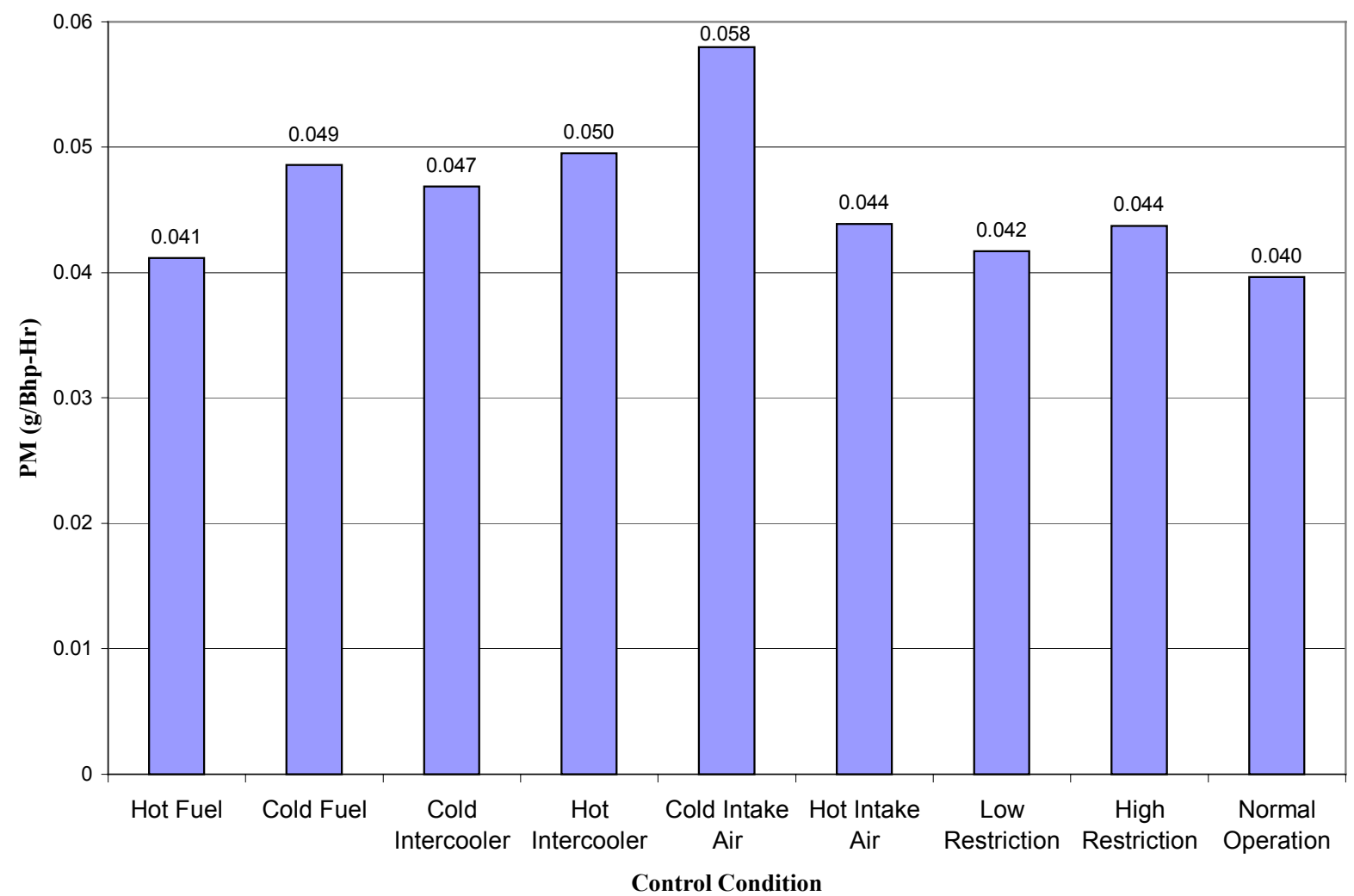

Figure 6-18: Effects of Engine and Ambient Conditions on Brake-specific PM Emissions for Simulated Bruceton Mills On-Road Cycle on WVU DC Engine Dynamometer 


\subsubsection{Brake-specific Fuel Consumption}

The BSFC varied by $3 \%$ from the minimum cold fuel test to the maximum hot fuel test. The fuel conditioning system accounted for the density fluctuation occurring with varying temperature, so this was not the cause of the variation. In all instances the hotter conditions required more fuel, as well as the increased engine restrictions.

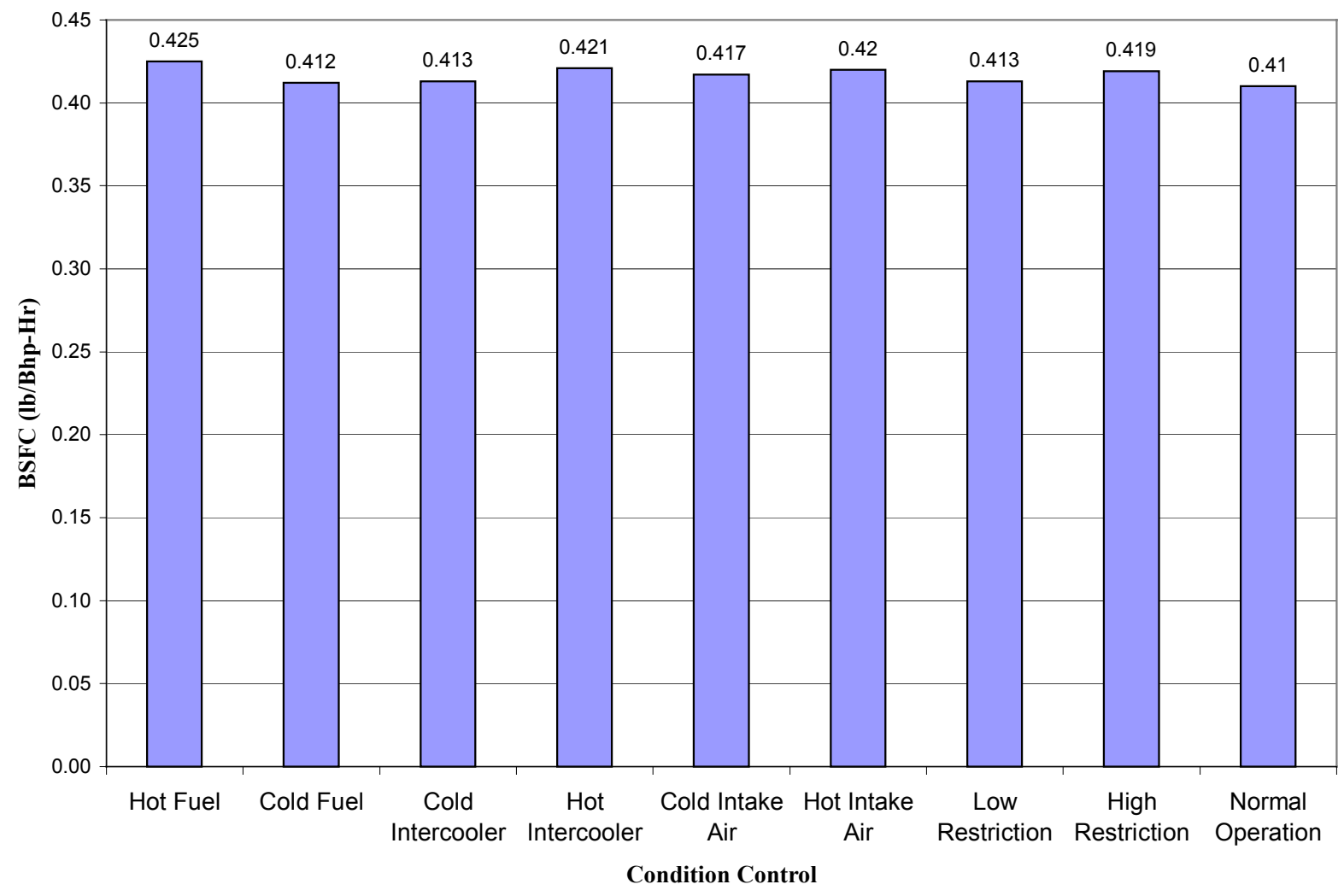

Figure 6-19: Effects of Engine and Ambient Conditions on BSFC for Simulated Bruceton Mills On-Road Cycle on WVU DC Engine Dynamometer 


\section{Conclusions}

Difference comparisons were calculated using the methods discussed in Chapter 6, and a visual aide in understanding these calculations is displayed in Figure 7-1. The average variation in work and emissions measurements in Bhp- $\mathrm{Hr}$ and $\mathrm{g} / \mathrm{Bhp}-\mathrm{Hr}$ respectively are displayed in flow chart format as seen in Figure 7-2. Appendix $\mathrm{E}$ includes the average variation for each engine tested on the dynamometer. Engines were labeled A-F due to the sensitivity of the information presented. The values in Figure 7-2 and Figure 7-3 are average or maximum variations from specific cycle data in Appendix E. Solid boxes signify variation in a measurement method from cycle-to-cycle and route-to-route. Dashed boxes signify the variation between measurement methods for similar routes and cycles. This method provides a means to correlate in-use, on-road data to a laboratory.

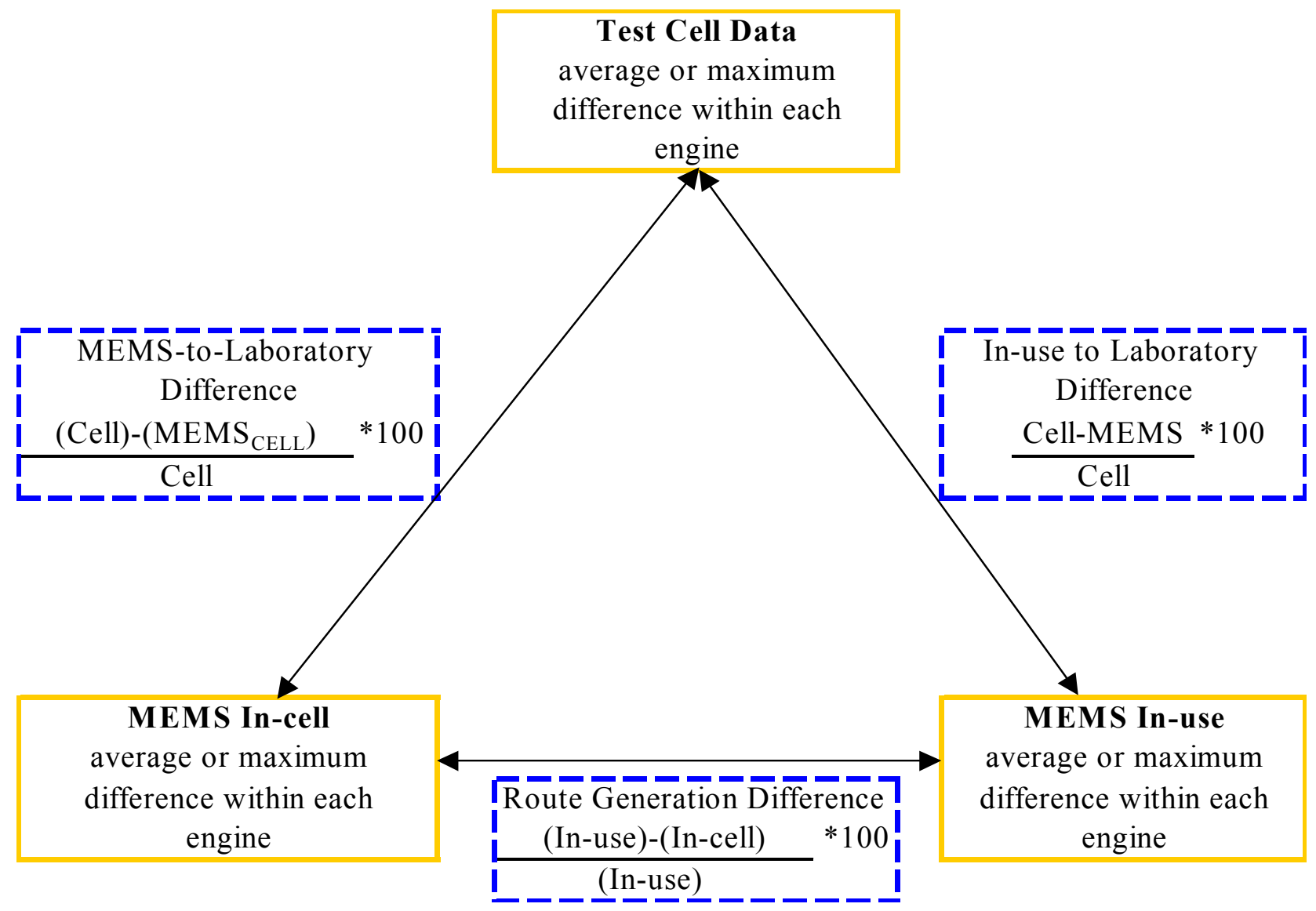

Figure 7-1: Method for Calculation of Values in Comparison Analysis 


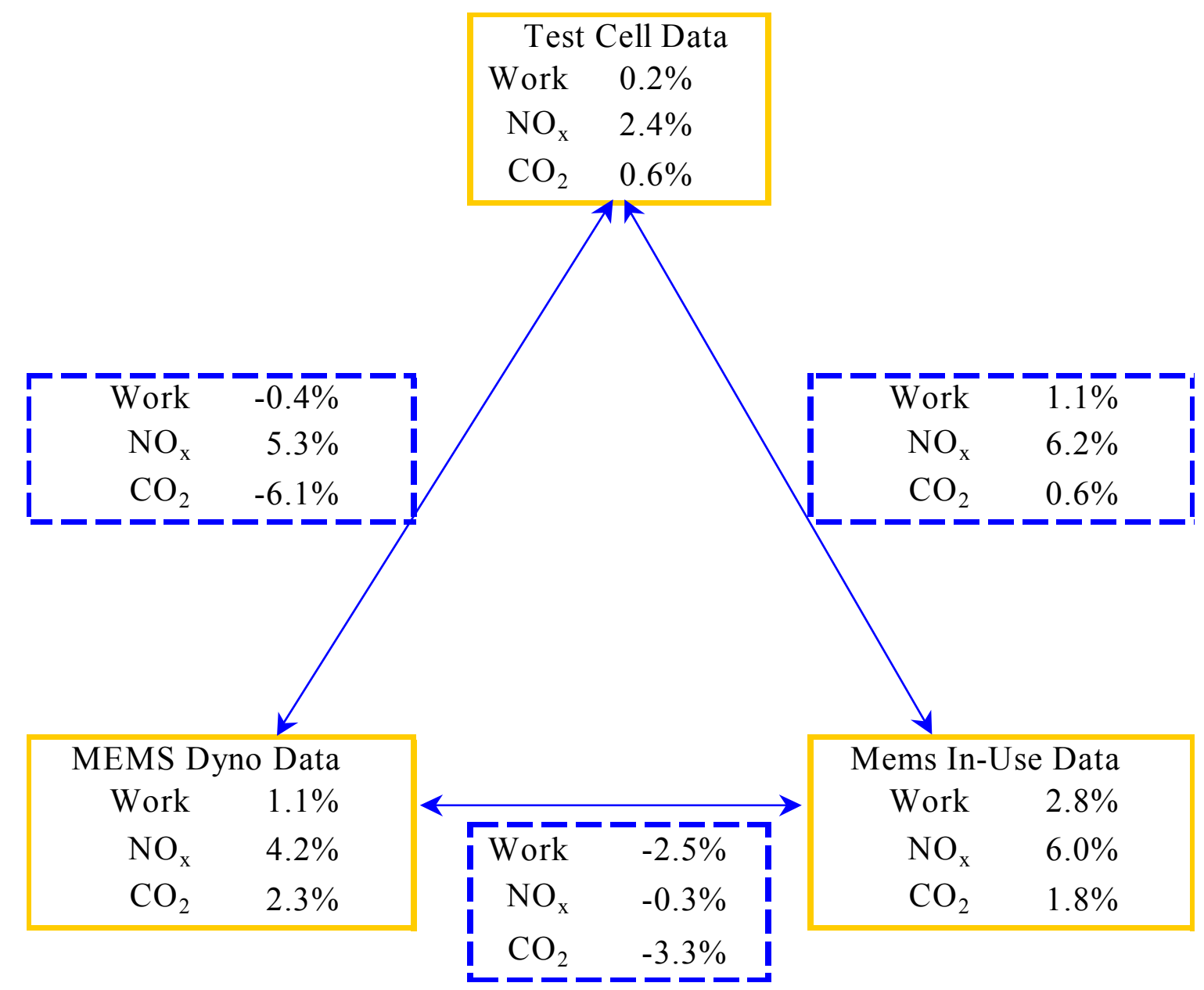

Figure 7-2: Average Variance in Diesel Engine Work and Emission Measurement for SAB2BM Cycles for Engines Tested on Dynamometer

Figure 7-3 displays the maximum recorded levels of variation in the tests performed.

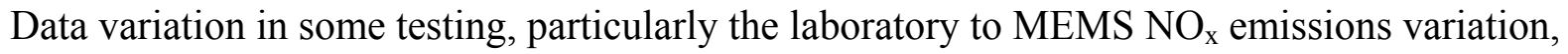
which is higher than expected. This is attributable to some identified cycles which emitted higher and lower levels than their similar repeated cycles. This may have been due to either engine related properties such as ECU timing issues, operator error in calibration or reduction, or in mechanical error in test cell components. However, all data presented has been extensively checked for errors. 


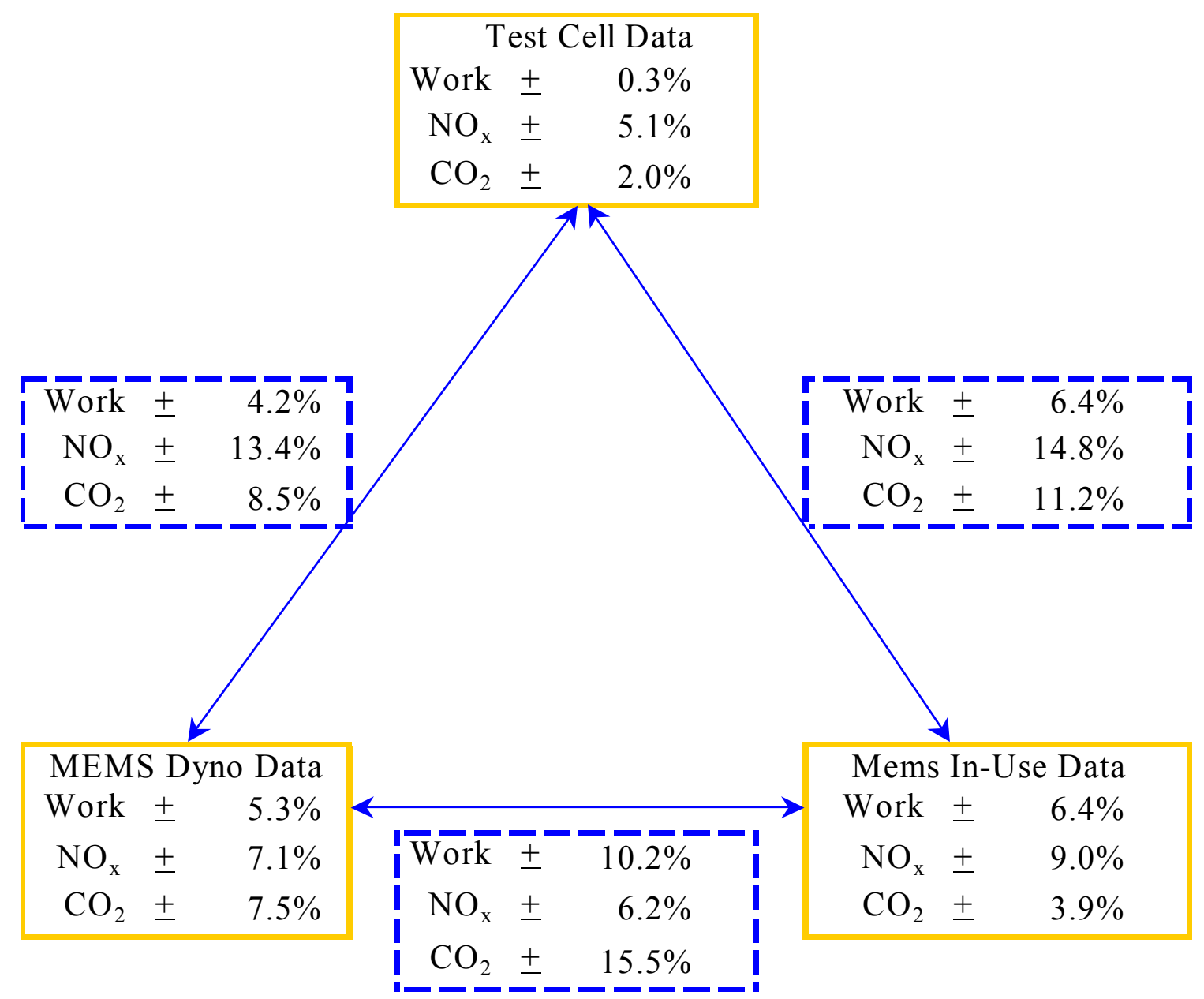

Figure 7-3: Maximum Variance in Diesel Engine Work and Emission Measurement for SAB2BM Cycles for Engines Tested on Dynamometer

\subsection{Route Variation}

Route variation was measured using both average and maximum percent variation methods. The average work variation, as shown in Figure 7-2, was 2.8\%. This is a low level of variation considering the random traffic patterns, ambient conditions, and vehicle operator driving style. The average $\mathrm{NO}_{\mathrm{x}}$ emission variation was $6.0 \%$, also low considering the large amount of variables present. The $\mathrm{CO}_{2}$ emission varied, on average, 1.8\% from route-to-route. The maximum values of variation are seen in Figure $7-3$ as $6.4 \%, 9.0 \%$, and $3.9 \%$ for Work, $\mathrm{NO}_{\mathrm{x}}$, and $\mathrm{CO}_{2}$ respectively. 


\subsection{Dynamometer Cycle Generation}

Conclusions on dynamometer cycle generation were best drawn from the variation between MEMS in-use and MEMS engine dynamometer cycles, the lower of the dashed boxes in Figure 7-2 and Figure 7-3. The average variation in work was $-2.5 \%$, meaning generally more work was done in the test cell than on the road. This may have been due to the lug curves selected for data reduction. The on-road data was reduced with a generic form supplied by the engine manufacturer, and dynamometer tests were reduced using lug curves measured in the test cell. Appendix F displays the continuous data comparison for in-use and in-cell tests for an example engine. The in-use data was taken from the cycle used in test cell route generation. Note the speed, torque, and power data is nearly identical. The $\mathrm{CO}_{2}$ emissions were lower onroad than in-cell, which may have been due to contaminated optical tubes. Note the significant increase in correlation as the $\mathrm{NO}_{\mathrm{x}}$ correction factor is applied. There was a noticeable difference in the flowrate at certain areas of the run, where the engine was coasting downhill, with a Jacobs exhaust brake in use, without an exhaust brake in-cell (the exhaust brake must be disabled for incell testing).

$\mathrm{NO}_{\mathrm{x}}$ emission measurements were on average $0.3 \%$ lower on road than in the test cell. This variation was within acceptable limitations. The $\mathrm{CO}_{2}$ emission measurement was on average 3.3\% lower on the road than in the test cell. Many factors may have influenced the $\mathrm{CO}_{2}$ produced by the vehicle, such as operating conditions and ambient $\mathrm{CO}_{2}$ concentrations. The average variance was a compilation of these parameters, as well as the variance in the system, and was on average less than $10 \%$ as seen in Figure 7-2.

\subsection{MEMS-Laboratory Comparison}

Comparisons were made between the laboratory and the MEMS analyzers, which may be used to qualify the MEMS system. It is noted during testing the addition of 30 seconds of MEMS data is present before and after the test cell data, in order to properly capture the entire data set read by the EERC. Table 7-1 displays the effects of the 30 second window on work calculations and emissions measurements. The integrated Bhp-Hr work was $0.4 \%$ higher with the removal of the 60 second idle. The $\mathrm{NO}_{\mathrm{x}}$ and $\mathrm{CO}_{2}$ were lower after the removal of the excess idle time, with negative difference signifying loss after the removal of the idle time. 
Table 7-1: Effects of 60 Second Idle Present in MEMS on Work and Emissions Measurements for Sample Diesel Engine SAB2BM Dynamometer Cycle

\begin{tabular}{|c|c|c|c|c|c|}
\cline { 3 - 6 } \multicolumn{2}{c|}{} & With 60 second idle & Without 60 second idle & Difference & $\%$ Differnce \\
\hline Work & Bhp-Hr & 9.51 & 9.55 & 0.034 & 0.4 \\
\hline $\mathrm{NO}_{x}$ & g/Bhp-Hr & 16.86 & 16.74 & -0.122 & -0.7 \\
\hline $\mathrm{CO}_{2}$ & $\mathrm{~g} / \mathrm{Bhp}-\mathrm{Hr}$ & 2214.1 & 2201.3 & -12.8 & -0.6 \\
\hline
\end{tabular}

The average work measured by the MEMS system was $0.4 \%$ higher than the laboratory measurements as seen in Figure 7-2, which would increase with the removal of the additional idle section in the MEMS data. For comparison, the left hand dashed box in Figure 7-2 and Figure 7-3 is used, the variation between the systems for engine dynamometer test cycles.

The removal of the 60 second idle time had $0.4 \%$ variation on the torque calculation. The variation may have occurred in the inference of torque, lug curve generation, or other system variations which are difficult to quantify.

The average brake-specific $\mathrm{NO}_{\mathrm{x}}$ emission was 5.3\% lower for the MEMS than for the laboratory analyzers. The removal of the 60 second idle times would increase this deficit. The average $\mathrm{CO}_{2}$ brake-specific emission measurement was $6.1 \%$ higher for MEMS than for the laboratory analyzers. The removal of the 60 seconds of idle time in MEMS data would lower the average error.

\subsection{Influences}

Three main influences control engine emissions and power output, ECU control strategy, operating conditions, and fuel properties. The first parameter, ECU control, was found to influence both emissions levels and repeatability. As displayed in Figure 7-4, the injection strategy changed from a low-emission mode to a higher $\mathrm{NO}_{\mathrm{x}}$ fuel economy mode during a sample SAB2BM dynamometer test. The engine manufacturers did not provide the engine control logic algorithms responsible for controlling this phenomenon, so reasoning for the switch is left to speculation.

The operating conditions were found to alter both the engine emission levels and the power output. These conditions are set as constants for engine dynamometer certification testing, but may vary in in-field testing. Filter loading, turbo operation, exhaust pipe geometry, and other factors may alter the typical air restrictions set in dynamometer testing. Ambient air temperature varied for in-use testing, and yielded a more realistic perspective of typical vocational engine 
operating temperatures. Fuel temperature may vary; as the fuel is often used to cool ECU modules, sent to the injectors, and returned to the tank. This, in addition to ambient heating of fuel tanks, may raise temperatures of the fuel. Cool ambient air may lower fuel temperature, and fuel pumped from underground tanks may be below dynamometer certification temperatures. Operational conditions studied varied $\mathrm{HC}$ emission by $26 \%$, $\mathrm{CO}$ emission by $11 \%, \mathrm{CO}_{2}$ emission by $4 \%, \mathrm{NO}_{\mathrm{x}}$ emission by $11 \%$, PM emission by $29 \%$, work output by $0.3 \%$, and $\mathrm{BSFC}$ by $3 \%$.

Fuel properties varied from supplier to supplier, and a differences were even discovered between separate stations of the same affiliation. Fuel was found to vary $\mathrm{HC}$ emissions by $19 \%$, $\mathrm{CO}$ emissions by $25 \%, \mathrm{CO}_{2}$ emissions by $3 \%, \mathrm{NO}_{\mathrm{x}}$ emission by $10 \%$, $\mathrm{PM}$ emission by $26 \%$, work by $0.3 \%$, and BSFC by $3 \%$.

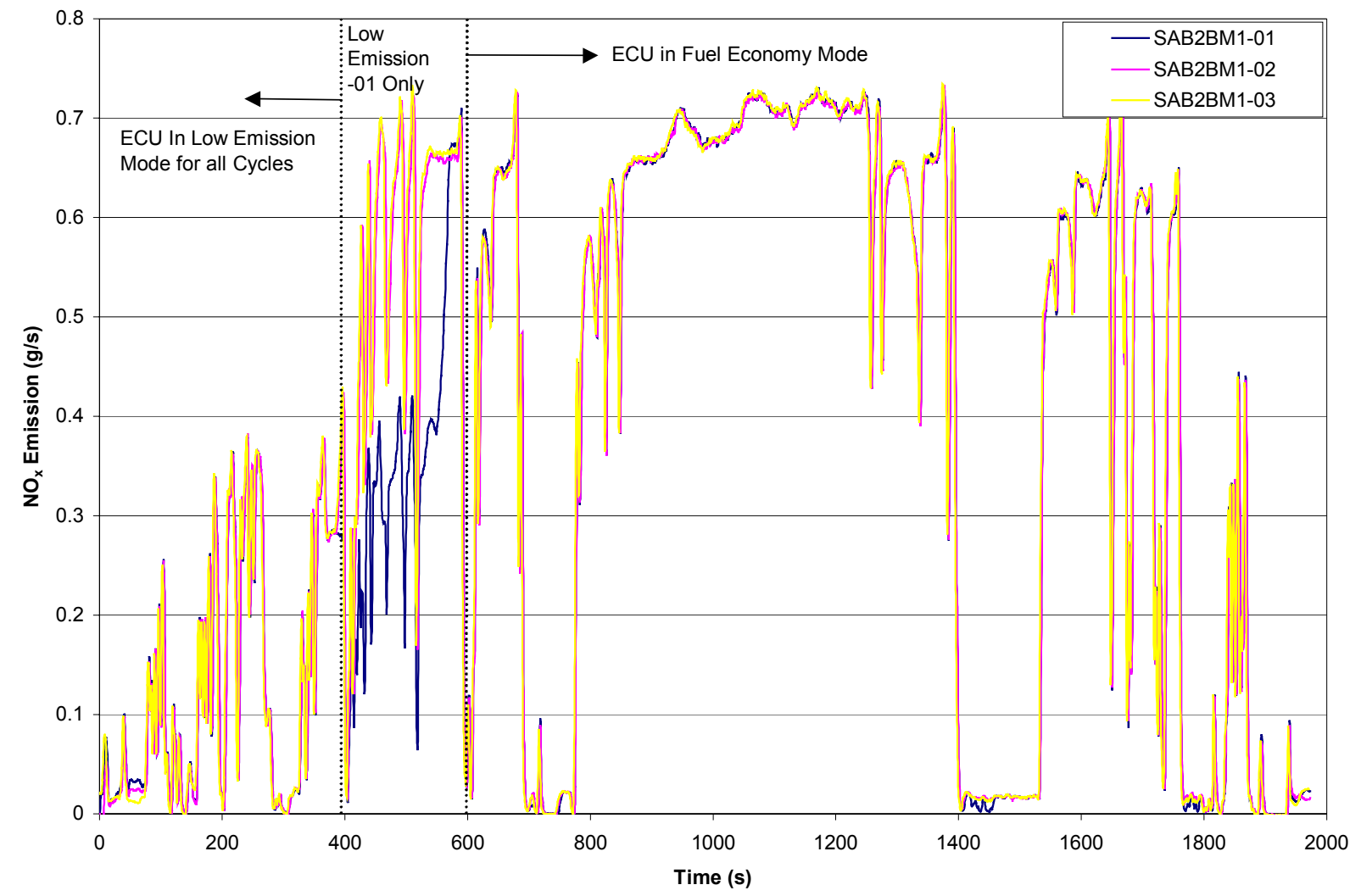

Figure 7-4: Influence of ECU on Engine $\mathrm{NO}_{\mathrm{x}}$ Emissions During Sample HDDE Engine Dynamometer SAB2BM Cycle

The combination of these influences largely influenced the level of engine emission. In-use testing was capable of measuring emission output for an in-use vehicle, accounting for some of the variables which may not be present in typical engine certification tests and test routes. 


\section{Recommendations}

On-board MEMS emissions testing and system development is beginning Phase IV as discussed in the Consent Decrees, and system improvements are being considered. Some of the improvements mentioned in this chapter are already underway, and some are left for future deliberation.

The proprietary $\mathrm{NO}_{\mathrm{x}}$ converter catalyst used in the MEMS systems may have undergone efficiency degradation, and the complete efficiency of the catalyst through its life was not well documented. Future studies may be performed to fully understand the catalyst conversion efficiency at varying concentrations and flow rates of $\mathrm{NO}_{\mathrm{x}}$, as well as the degradation of the catalyst over time.

The Horiba BE-140 optical tube life expectancy is unknown at this time. It is noted the NDIR analyzer was found to be slightly biased at the conclusion of the test, which may in part be due to an accumulation of soot in the optical cell. Regular cell cleaning or replacement may be necessary.

Advances in flow rate measurement technology have been made, and studies are ongoing to determine the accuracy of these methods. One system of particular interest is the AEI SPOT converging nozzle apparatus.

Water condensation in the lines leading from the Annubar head outlet to the pressure transducers lead to sensor bias and drift during on-road testing. Heated enclosures have been fabricated to protect the lines from the ambient air to reduce condensation.

The ambient box was generally inaccurate during the testing. The humidity sensor has low levels of accuracy. Solid-state humidity sensors are available. Though costly, these sensors, in addition to ambient pressure and temperature modules, may prove worthwhile investments. A sling psychromoter does provide a $\mathrm{QA} / \mathrm{QC}$ check, and was used for correction equations in data reduction.

Uncertainty existed in the methods used to calculate dry-to-wet emission concentrations for the post-chiller $\mathrm{CO}_{2}$ and $\mathrm{EC}$ measurement devices. If the chiller temperature was not properly controlled and some water vapor remained in the sample, an under-estimation of the $\mathrm{CO}_{2}$ and $\mathrm{EC}$ $\mathrm{NO}_{\mathrm{x}}$ levels may have occurred. A more in-depth analysis of the validity of the methods should be performed.

The data acquisition board provided by National Instruments was found to produce error 
when performing $\mathrm{A} / \mathrm{D}$ conversion. In the case of exhaust temperature thermocouple failure, a bias was created in the system which was found to affect the Annubar differential pressure transducer measured output. It is recommended steps be taken to account for or remove this bias.

Exhaust temperature measurement thermocouple lines were found to fatigue and fail during in-use testing. Solid strand lines have been replaced with multi-strand wiring to avoid fracture. Rusting was also evident in thermocouple wire connections exposed to ambient conditions. A change to corrosion-resistant K-type thermocouples is planned.

It was discovered some of the standard calibration gas concentrations were not within the supplier's specified accuracies. SRM bottles were used to specify more accurate measurements of several gas bottle concentrations, and may prove a significant means to reduce calibration error in future testing.

The background emissions for the routes tested were unknown. Studies on background emission levels and variance may aide in the qualification of the in-use system, though raw exhaust sampling provides an accurate estimation of the elements produced in the engine of interest as the background air undergoes the combustion process. 


\section{References}

1. "Emissions Standards: USA Heavy-duty Truck and Bus Engines," Rev. 01/11a. DieselNet, Ecopoint Inc. 1997-2003.

2. Riddle, W. C., "Design and Evaluation of the Emissions Measurement Components for a Heavy-Duty Diesel Powered Vehicle Mobile Emissions Measurement System (MEMS)," M.S. Thesis, Department of Mechanical and Aerospace Engineering, West Virginia University, Morgantown, WV, 2001.

3. Shade, B.C., "A Performance Evaluation of the MEMS -An On-Road Emissions Measurement System Study," M.S. Thesis, Department of Mechanical and Aerospace Engineering, West Virginia University, Morgantown, WV, 2000.

4. Gautam, M., Clark, N. N., Thompson, G. J., and Lyons, D. W., "Assessment of Mobile Monitoring Technologies for Heavy-Duty Vehicle Emissions," White paper Submitted to the Settling Heavy-Duty Diesel Engine Manufacturers, Department of Mechanical and Aerospace Engineering, West Virginia University, Morgantown, WV, 1999.

5. Branstetter, R., Burrahm, R., and Dietzmann, H., "Relationship of Underground Diesel Engine Maintenance to Emissions," Final Report for 1978 to 1983 to the U.S. Bureau of Mines, Department of the Interior Contract H0292009, 1983.

6. Chan, L., Carlson, D. H., and Johnson, J. H., "Evaluation and Application of a Portable Tailpipe Emissions Measurement Apparatus for Field Use," SAE Technical Paper No. 921647, Warrendale, PA, 1992.

7. Spears, M. W., "An Emissions-Assisted Maintenance Procedure for Diesel-Powered Equipment," University of Minnesota, Center for Diesel Research, Minneapolis, MN, 1997.

8. Englund, M. S., "Field Compatible NOx Emission Measurement Technique," SAE Technical Paper No. 820647, Warrendale, PA, 1982.

9. Human, D. M. and Ullman, T. L., "Development of an I/M Short Emissions Test for Buses," SAE Technical Paper No. 920727, 1992.

10. Kelly, N. A. and Groblicki, P. J., "Real-world emissions from a modern production vehicle driven in Los Angeles," Journal of the Air \& Waste Management Association, Vol. 43, No.10, 1993.

11. Mackay, G. I., Nadler, S. D., Karecki, D. R., Schiff, H. I., Butler, J. W., Gierczak, C. A., and Jesion, G., "Dynamometer Intercomparison of Automobile Exhaust Gas $\mathrm{CO} / \mathrm{CO}_{2}$ Ratios and Temperature Between On-Board Measurements and a Remote Sensing Near Infrared Diode Laser System," Phase 1b Report to the Coordinating Research Council and National Renewable Energy Laboratory, 1994. 
12. Mackay, G. I., Nadler, S. D., Karecki, D. R., Schiff, H. I., Butler, J. W., Gierczak, C. A., and Jesion, G., "Test Track Intercomparison of Automobile Exhaust Gas $\mathrm{CO} / \mathrm{CO}_{2}$ Ratios and Temperature Between On-Board Measurements and a Remote Sensing Near Infrared Diode Laser System," Phase 1c Report to the Coordinating Research Council and National Renewable Energy Laboratory, 1994.

13. Butler, J. W., Gierczak, C. A., Jesion, G., Stedman, D. H., and Lesko, J. M., "On-Road NOx Emissions Intercomparison of On-Board Measurements and Remote Sensing," Final Report, Coordinating Research Council, Inc., Atlanta, GA, CRC Report No. VE-11-6, 1994.

14. Gierczak, C. A., Jesion, G, Piatak, J. W., and Butler, J. W., "On-Board Vehicle Emissions Measurement Program," Final Report, Coordinating Research Council, Inc., Atlanta, GA, CRC Report No. VE-11-1, 1994.

15. Bentz, A. P. and Weaver, E., "Marine Diesel Exhaust Emissions Measured by Portable Instruments," SAE Technical Paper No. 941784, Warrendale, PA, 1994.

16. Bentz, A. P., "Final Summary Report on Project 3310, Marine Diesel Exhaust Emissions (Alternative Fuels)," United States Department of Transportation United States Coast Guard Systems, Report No. CG-D-08-98, 1997.

17. Vojtisek-Lom, M. and Cobb, Jr., J. T., "On-Road Light-Duty Vehicle Mass Emission Measurements Using a Novel Inexpensive On-Board Portable System," Proceedings of the Eighth CRC On-Road Vehicle Workshop, San Diego, CA, April 20-22, 1998.

18. Knight, J. K., "Measurement of Total Hydrocarbon Emissions with MEMS using a Portable FID and a Novel Exhaust Flow Meter," M.S. Thesis, Department of Mechanical and Aerospace Engineering, West Virginia University, Morgantown, WV, 2002.

19. "Construction Equipment Retrofit Project," Northeast States for Coordinated Air Use Management, Boston, MA, 1998.

20. Butler, J. W., Kornisk, T. J., Reading, A. R., and Kotenko, T. L., "Dynamometer Quality Data On-board Vehicles for Real-World Emission Measurements," Proceedings of the Ninth CRC On-Road Vehicle Workshop, April 19-21, San Diego, CA, 1999.

21. Kihara, N., Tsukamoto, T., Matsumoto, K., Ishida, K., Kon, M., and Murase, T., "Real-time On-board Measurement of Mass Emission of NOx, Fuel Consumption, Road Load, and Engine Output for Diesel Vehicles," SAE Technical Paper No. 2000-01-1141, Warrendale, PA, 2000.

22. Truex, T. J., Collins, J. F., Jetter, J. J., Knight, B., Hayashi, T., Kishi, N., and Suzuki, N., "Measurement of Ambient Roadway and Vehicle Exhaust Emissions-An Assessment of Instrument Capability and Initial On-Road Test Results with an Advanced Low Emission Vehicle," SAE Technical Paper No. 2000-01-1142, Warrendale PA, 2000. 
23. Brown, E. J., F. G. King, W. A. Mitchell, W. C. Squier, D. B. Harris, and J. S. Kinsey . “OnRoad Facility to Measure and Characterize Emissions from Heavy-Duty Diesel Vehicles," J. Air \& Waste Manage. Assoc., 52:388-395, 2002.

24. Brown, E. J. "Heavy Duty Diesel Fine Particulate Matter Emissions: Development and Application of On-Road Measurement Capabilities,” EPA-600/R-01-079, U. S. Environmental Protection Agency, Research Triangle Park, NC, October, 2001.

25. Jetter, J., Maeshiro, S., Hatcho, S. and Klebba, R., "Development of an On-Board Analyzer for Use on Advanced Low Emission Vehicles," SAE Technical Paper No. 2000-01-1140, Warrendale, PA, 2000.

26. Ikonen, M, Westerholm, M. and Nyulnd, N, "Emission and Fuel Consumption Measurements for Transit Buses Running on Gaseous Fuels Using a Mobile Measurement System," SAE Technical Paper No. 2001-02-3638, Warrendale, PA, 2001.

27. Vojtisek-Lom, M. and Allsop, J. E., "Development of Heavy-Duty Diesel Portable, OnBoard Mass Exhaust Emissions Monitoring System With NOx, CO2, And Qualitative PM Capabilities," SAE Technical Paper No. 2001-01-3641, Warrendale, PA, 2001.

28. Hanover, S., Audi, BMW, Mercedes Benz (passenger \& HGV), OPEL, Porshe, and VW, "Vehicle Electrical Systems Architecture," Position paper, February 1996.

29. Czachura, B., Brandon, L. and May, A., "Demonstration of the 'Simple, Portable On-Vehicle Testing' (SPOT) System on a Class 8 Vehicle," Proceedings of the 11th CRC On-Road Vehicle Emissions Workshop, 2001.

30. Weaver, C. S. and Balam-Almanza, M.V. "Development of the 'RAVEM' Ride-Along Vehicle Emissions Measurement System for Gaseous and Particulate Emissions," SAE Technical Paper No. 2001-01-3644, Warrendale, PA, 2001.

31. Weaver, C., S., Chan, L. and Petty, L., "Measurement of Air Pollotant Emissions From InService Passanger Ferries," Engine, Fuel, and Emissions Engineering, Inc., Emission data report submitted to San Francisco Bay Area Water Transit Authority, 2002.

32. Reading, A., Gideon, E., and Ensfield, C., "The Design and Implementation of a Portable Analytical System (SEMTECH) for the Measurement of In-Use Diesel Engine Emissions," Proceedings of the 11th CRC On-Road Vehicle Emissions Workshop, 2001.

33. "SEMTECH-D On-Board, In-Use Diesel Vehicle Emissions Analyzer," Rev 10-7-02. Sensors Inc., Saline, MI

34. Hawirko, J. D. and Checkel, D. M, "Quantifying Vehicle Ambient Conditions using an OnRoad, Real-Time Emissions System,” SAE Technical Paper No. 2003-01-0301, Warrendale, PA, 2003. 
35. Mann, N., Kvinge, F. and Wilson, G., "Diesel Fuel Effects on Emissions- Towards a Better Understanding," SAE Technical Paper No. 982486, Warrandale, PA, 1998.

36. Broering, L. C. and Holtman, L. W., "Effect of Diesel Fuel Properties on Emissions and Performance," SAE Technical Paper No. 740692, Warrendale, PA, 1974.

37. Baranescu, R., "Influence of Fuel Sulfur on Diesel Particular Emissions,” SAE Technical Paper No. 881174, Warrandale, PA, 1988.

38. Ulman, T. L., Mason, R. L. and Montalvo, D. A., "Study of Fuel Cetane Number and Aromatic Content Effects on Regulated Emissions From a Heavy-Duty Diesel Engine," Final Report CRC Contract No VE-1, SwRI 08-2940, San Antonio, TX, September, 1990.

39. Asaumi, Y., Shintani, M. and Watanabe, Y., "Effects of Fuel Properties on Diesel Engine Exhaust Emission Characteristics," SAE Technical Paper No. 922214, Warrandale, PA, 1992.

40. Den Ouden, C., Clark, R., Cowley, L. and Stradling, J., "Fuel Quality Effects on Particulate Matter Emissions from Light- and Heavy-Duty Diesel Engines," SAE Technical Paper No. 942022, Warrandale, PA, 1994.

41. Virk, K. S. and Lachowicz, D. R., "Testing of Diesel Fuels for Their Effects on Exhaust Emissions and Engine Performance," SAE Technical Paper No. 952362, Warrandale, PA, 1995.

42. Geiman, R., Cullen, P., Chant, P., Carlson, P. and Rao, V., "Emission Effects of Shell LOW NOX Fuel on a 1990 Model Year Heavy-Duty Diesel Engine," SAE Technical Paper No. 961973, Warrandale, PA, 1996.

43. Schaberg, P., Myburgh, I., Botha, J., Roets, P. and Viljoen, C., "Diesel Exhaust Emissions Using Sasol Slurry Phase Distillate Process Fuels,” SAE Technical Paper No. 972898, Warrandale, PA, 972898.

44. Clark, N. N., Atkinson, C. M., Thompson, G. J. and Nine, R. D., "Transient Emissions Comparisons of Alternative Compression Ignition Fuels," SAE Technical Paper No. 199901-1117, Warrandale PA, 1999.

45. Atkinson, C. M., Thompson, G. J., Traver, M. L. and Clark, N. N., "In-Cylinder Combustion Pressure Characteristics of Fischer-Tropsch and Conventional Diesel Fuels in a Heavy Duty CI Engine," SAE Technical Paper No. 1999-02-1472, Warrandale, PA, 1999.

46. Morita, A. and Sugiyama, G., "Influence of Density and Viscosity of Diesel Fuel on Exhaust Emissions," SAE Technical Paper NO. 2003-01-1869, Warrandale, PA, 1992. 
47. "Code of Federal Regulations," CFR 40 Part 86, Office of the Federal Register National Archives and Records Administration, Washington, D.C., 1994.

48. Gautam, M., Clark, N. N., Thompson, G. J., Carder, D. K., and Lyons, D. W., "Development of In-Use Testing Procedures for Heavy-duty Diesel-Powered Vehicle Emissions," Phase II Report, Submitted to the Settling Heavy-Duty Diesel Engine Manufacturers by West Virginia University, Morgantown, WV, March, 2000.

49. Gautam, M., Clark, N. N., Thompson, G. J., Carder, D. K., Riddle, W. C., and Lyons, D. W., "Evaluation of In-Use Heavy-Duty Vehicle Emissions Using the Mobile Emissions Measurement System (MEMS)," Phase III Report, Submitted to the Settling Heavy-Duty Diesel Engine Manufacturers by West Virginia University, Morgantown, WV, December, 2002.

50. Instruction Manual - MEXA NO $\underline{x}$ Analyzer, Horiba, Ltd. First Edition, Ver. 1.0, Kyoto Japan, .September, 1998.

51. Installation Manual - Horiba Model BE-140 AD Production Type Exhaust Gas Analyzer, Horiba, Ltd. First Edition, Kyoto, Japan, June 30, 1997.

52. Standard Outline Dimensional Drawing for Annubar Primary Flow Element, Drawing No. C-3602, Dietrich Standard, Boulder, CO, April 26, 1999.

53. Meyer, E.T., "Evaluation of Exhaust Flowrate Measurement Techniques for a Mobile Emissions Measurement System," M.S. Thesis, Department of Mechanical and Aerospace Engineering, West Virginia University, Morgantown, WV, 2001.

54. Thompson, G. J., Clark, N. N., Gautam, M., Carder, D. K., and Lyons, D. W., "Inference of Torque and Power from Heavy-Duty Diesel Engines for On-road Emissions Monitoring," SAE Technical Paper No. 2002-01-0614, Warrendale, PA, 2002.

55. "Notice of Filing of Consent Decree Under the Clean Air Act," Federal Register, Vol. 63, No. 212, Office of the Federal Register, National Achieves and Records Administration, Washington DC, November 3, 1998.

56. Diesel Fuels Technical Review (FTR-2), Chevron Products Company, 1998.

57. Haywood, John B., Internal Combustion Engine Fundamentals, McGraw-Hill, New York, NY, 1998.

58. Hsu, Bertrand D., Practical Diesel-Engine Combustion Analysis, SAE International, Warrendale PA, 2002. 


\section{Appendix A. Accuracy of System Components}

Table A-1: MEMS System Component Accuracy

\begin{tabular}{|c|c|c|c|}
\hline Component & Manufacturer & Model Number & Accuracy \\
\hline EC NOx Analyzer & Sensors, Inc & AMBII & $+4 \%$ of reading \\
\hline Absolute Pressure & Omega & $\mathrm{P} \times 213$ & $\pm 0.25 \%$ Full Scale \\
\hline Absolute Pressure & Heise & PTE-1 & $\pm 0.06 \%$ Full Scale \\
\hline Calibration Gas & Airgas & - & $+1 \%$ \\
\hline $\mathrm{CO}_{2}$ Analyzer & Horiba & BE140 & $\pm 20 \%$ vol for $\mathrm{CO}_{2}$ \\
\hline DAQ board & National Instruments, Inc. & NI-6024E & $\pm 0.0244 \%$ \\
\hline Differential Pressure & Validyne & P55D & $\pm 0.25 \%$ \\
\hline Exhaust Flow Rate & Annubar & DCR-25S & $+1 \%$ Full Scale \\
\hline Gas Divider & CAHN & $\mathrm{C}-32$ & $+0.2 \%$ \\
\hline GPS Sensor & Garmin & GPS 36 & \pm 15 meters \\
\hline Signal Conditioner & National Instruments, Inc. & SCC-AI104 & $+0.1 \%$ \\
\hline SRM Reference Gas & Airgas & - & $+0.5 \%$ \\
\hline Temperature & Omega & J-type & $+0.25 \%$ \\
\hline $\mathrm{ZrO}_{2} \mathrm{NO}_{\mathrm{x}}$ Analyzer & MEXA & 120 & $\pm 3 \%$ reading \\
\hline $\mathrm{NO}_{\mathrm{x}}$ Converter Catalyst & & & unknown \\
\hline
\end{tabular}

Table A-2: Laboratory Test Cell Component Accuracy

\begin{tabular}{|c|c|c|c|}
\hline Component & Manufacturer & Model Number & Accuracy \\
\hline AD Converter & Analog Devices & $3 \mathrm{~B}$ & $\pm 0.1 \%$ Full Scale \\
\hline Calibration Gas & Airgas & - & $\pm 1 \%$ Full Scale \\
\hline CO Analyzer & Horiba & AIA-210LE & $\pm 2 \%$ Full Scale \\
\hline $\mathrm{CO}_{2}$ Analyzer & Horiba & AIA-210 & $\pm 2 \%$ Full Scale \\
\hline dp transducer & SMAR & LD301 & $\pm 0.075 \%$ \\
\hline Fuel Flow Counter & MAX Machinery & 710 & $\pm 0.5 \%$ \\
\hline Gas Divider & STEC Inc. & SGD-710C & $\pm 0.2 \%$ \\
\hline HC Analyzer & Rosemount Analytical & 402 & $\pm 2 \%$ Full Scale \\
\hline Intake Air Flow & Meriam Instrument LFE & $50 \mathrm{MC} 2-6$ & $\pm 0.7 \%$ \\
\hline NO ${ }_{x}$ Analyzer & Rosemont Analytical & 955 & $\pm 2 \%$ Full Scale \\
\hline PM Mass Balance & CAHN & C-32 & \pm 1 microgram \\
\hline SRM Reference Gas & NIST & - & $\pm 0.5 \%$ \\
\hline Torque Load Cell & Lebow Eaton & 3132 & $\pm 1 \%$ \\
\hline
\end{tabular}




\section{Appendix B. WVU EERC HDDE Emissions Laboratory Schematic}

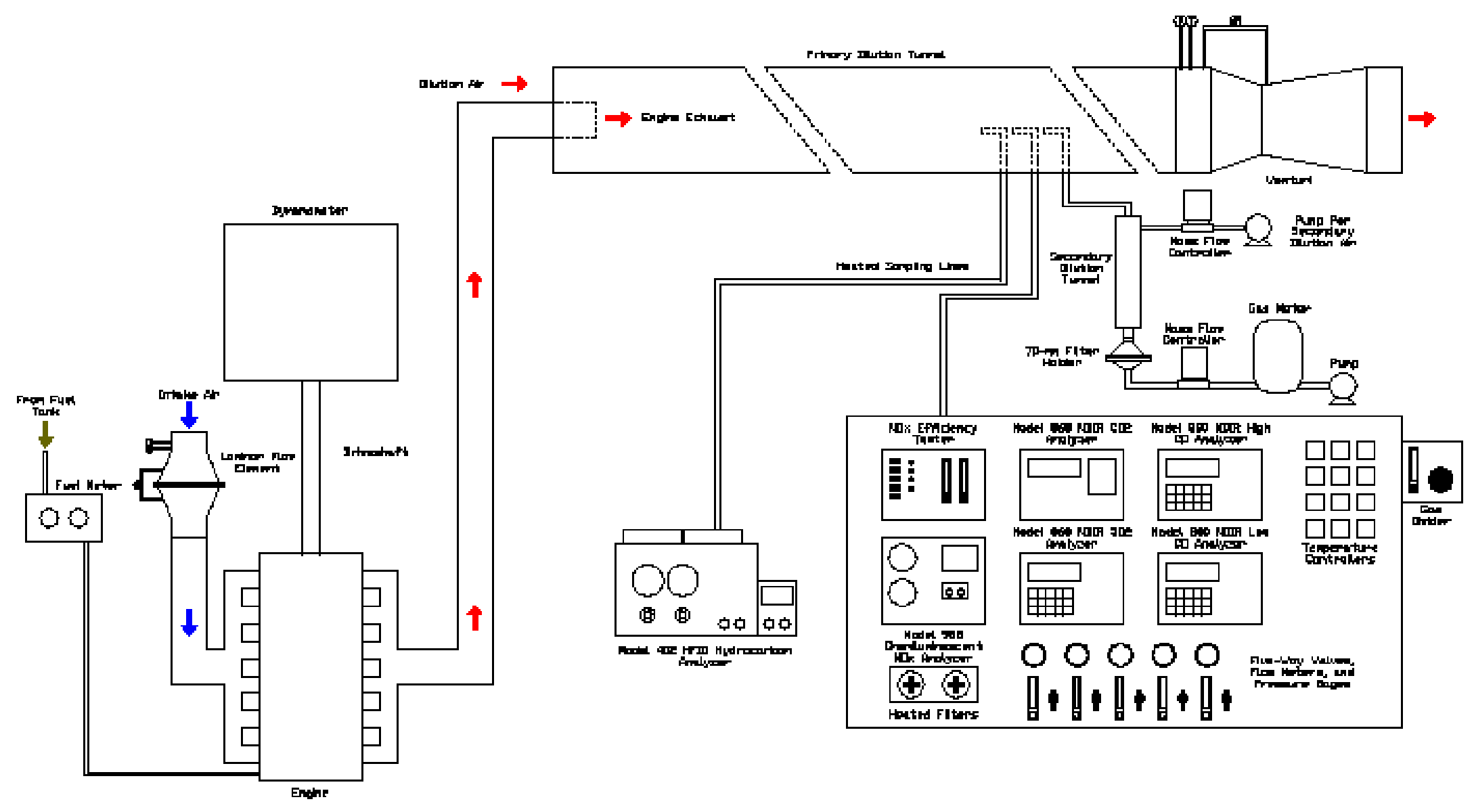

Figure B-1: WVU EERC HDDE Emissions Laboratory Schematic [3] 


\section{Appendix C. Results of Analytical Fuel Property Tests}

\begin{tabular}{|c|c|c|c|c|c|}
\hline \multicolumn{6}{|l|}{ Analytical Report } \\
\hline Sample Number: & 130287-004 & Sample ID: & \multicolumn{3}{|l|}{ 1/21/03 Carb Fuel } \\
\hline Sample Date: & $1 / 21 / 2003$ & Description: & & & \\
\hline Test & Result & Units & Method & Date & Analyst \\
\hline API Gravity@60 Deg. F & 36.4 & deg.API & ASTM D-1298 & $3 / 4 / 2003$ & FB \\
\hline Carbon & 86.17 & $\mathrm{wt} \%$ & ASTM D-5291M & $3 / 5 / 2003$ & QTI* \\
\hline Cetane Index, Calculated & 46.3 & ASTM D-976 & $3 / 12 / 2003$ & GLC & \\
\hline Cetane Number & 44.6 & ASTM D-613 & $3 / 6 / 2003$ & FB & \\
\hline \multicolumn{6}{|l|}{ Distillation } \\
\hline IBP & 353.2 & deg.F & ASTM D-86 & $3 / 7 / 2003$ & PW \\
\hline $5 \% \operatorname{Rec}$ & 381.1 & deg.F & & & \\
\hline $10 \% \operatorname{Rec}$ & 393.6 & deg.F & & & \\
\hline $20 \% \operatorname{Rec}$ & 414.5 & deg.F & & & \\
\hline $30 \% \operatorname{Rec}$ & 436.5 & deg.F & & & \\
\hline $40 \% \operatorname{Rec}$ & 460.2 & deg.F & & & \\
\hline $50 \% \operatorname{Rec}$ & 487.4 & deg.F & & & \\
\hline $60 \%$ Rec & 518.4 & deg.F & & & \\
\hline $70 \%$ Rec & 552.6 & deg.F & & & \\
\hline $80 \%$ Rec & 587.3 & deg.F & & & \\
\hline $90 \%$ Rec & 627.1 & deg.F & & & \\
\hline $95 \% \operatorname{Rec}$ & 657.8 & deg.F & & & \\
\hline FBP & 668.6 & deg.F & & & \\
\hline Recovery & 97.8 & $\%$ & & & \\
\hline Residue & 1 & $\%$ & & & \\
\hline Loss & 1.2 & $\%$ & & & \\
\hline Flash Point, PMCC & 146.2 & deg.F & ASTM D-93(A) & $3 / 4 / 2003$ & FB \\
\hline \multicolumn{6}{|l|}{ Hydrocarbon Type - FIA } \\
\hline Aromatics & 9 & $1 \mathrm{v} \%$ & ASTM D-1319 & $3 / 11 / 2003$ & FB \\
\hline Olefins & 1 & $1 \mathrm{v} \%$ & $3 / 11 / 2003$ & $\mathrm{FB}$ & \\
\hline Saturates & 90 & $1 \mathrm{v} \%$ & $3 / 11 / 2003$ & FB & \\
\hline Hydrogen Content & 13.76 & wt $\%$ & ASTM D-5291M & $3 / 5 / 2003$ & QTI* \\
\hline Kinematic Viscosity@40 deg. C & 2.64 & $\mathrm{cSt}$ & ASTM D-445 & $3 / 12 / 2003$ & $\mathrm{OE}$ \\
\hline Specific Gravity & 0.8428 & (a) 60 deg.F & ASTM D-1298 & $3 / 10 / 2003$ & GLC \\
\hline Total Sulfur & 0.0173 & wt $\%$ & ASTM D-4294 & $3 / 6 / 2003$ & RMT \\
\hline
\end{tabular}


Table C-2: Mt. Morris Citgo Fuel Analytical Report

\begin{tabular}{|c|c|c|c|c|c|}
\hline \multicolumn{6}{|l|}{ Analytical Report } \\
\hline Sample Number: & $130287-001$ & Sample ID: & \multicolumn{3}{|l|}{ Mt Morris Citgo } \\
\hline Sample Date: & $1 / 16 / 2003$ & Description: & & & \\
\hline Test & Result & Units & Method & Date & Analyst \\
\hline API Gravity@60 Deg. F & 42.4 & deg.API & ASTM D-1298 & $3 / 4 / 2003$ & FB \\
\hline Carbon & 85.77 & $w t \%$ & ASTM D-5291M & $3 / 5 / 2003$ & QTI* \\
\hline Cetane Index, Calculated & 54.2 & ASTM D-976 & $3 / 12 / 2003$ & GLC & \\
\hline Cetane Number & 53.8 & ASTM D-613 & $3 / 6 / 2003$ & FB & \\
\hline \multicolumn{6}{|l|}{ Distillation } \\
\hline IBP & 349.6 & deg.F & ASTM D-86 & $3 / 7 / 2003$ & PW \\
\hline $5 \% \operatorname{Rec}$ & 370.8 & deg.F & & & \\
\hline $10 \% \operatorname{Rec}$ & 382.1 & deg.F & & & \\
\hline $20 \% \operatorname{Rec}$ & 399.6 & deg.F & & & \\
\hline $30 \% \operatorname{Rec}$ & 419.9 & deg.F & & & \\
\hline $40 \% \operatorname{Rec}$ & 441.9 & deg.F & & & \\
\hline $50 \% \operatorname{Rec}$ & 468.9 & deg.F & & & \\
\hline $60 \% \operatorname{Rec}$ & 499.3 & deg.F & & & \\
\hline $70 \%$ Rec & 530.3 & deg.F & & & \\
\hline $80 \%$ Rec & 559.8 & deg.F & & & \\
\hline $90 \% \operatorname{Rec}$ & 588.2 & deg.F & & & \\
\hline $95 \% \operatorname{Rec}$ & 606.7 & deg.F & & & \\
\hline FBP & 627.1 & deg.F & & & \\
\hline Recovery & 98.7 & $\%$ & & & \\
\hline Residue & 1.1 & $\%$ & & & \\
\hline Loss & 0.2 & $\%$ & & & \\
\hline Flash Point, PMCC & 144.1 & deg.F & ASTM D-93(A) & $3 / 4 / 2003$ & FB \\
\hline \multicolumn{6}{|l|}{ Hydrocarbon Type - FIA } \\
\hline Aromatics & 14.3 & $1 \mathrm{v} \%$ & ASTM D-1319 & $3 / 11 / 2003$ & FB \\
\hline Olefins & 1.8 & $1 v \%$ & $3 / 11 / 2003$ & FB & \\
\hline Saturates & 83.9 & $1 v \%$ & $3 / 11 / 2003$ & FB & \\
\hline Hydrogen Content & 13.92 & $w t \%$ & ASTM D-5291M & $3 / 5 / 2003$ & QTI* \\
\hline Kinematic Viscosity@40 deg. C & 2.04 & $\mathrm{cSt}$ & ASTM D-445 & $3 / 12 / 2003$ & $\mathrm{OE}$ \\
\hline Specific Gravity & 0.8137 & (a) 60 deg.F & ASTM D-1298 & $3 / 10 / 2003$ & GLC \\
\hline Total Sulfur & 0.0381 & $w t \%$ & ASTM D-4294 & $3 / 6 / 2003$ & RMT \\
\hline
\end{tabular}


Table C-3: Beechurst Citgo Analytical Report

\begin{tabular}{|c|c|c|c|c|c|}
\hline \multicolumn{6}{|l|}{ Analytical Report } \\
\hline Sample Number: & 130287-002 & Sample ID: & \multicolumn{3}{|l|}{ Beechurst Citgo } \\
\hline & 1/17/2003 & Description: & & & \\
\hline Test & Result & Units & Method & Date & Analyst \\
\hline API Gravity@60 Deg. F & 35.2 & deg.API & ASTM D-1298 & $3 / 4 / 2003$ & FB \\
\hline Carbon & 86.86 & $w t \%$ & ASTM D-5291M & $3 / 5 / 2003$ & QTI* \\
\hline Cetane Index, Calculated & 46.9 & ASTM D-976 & $3 / 12 / 2003$ & GLC & \\
\hline Cetane Number & 45.4 & ASTM D-613 & $3 / 6 / 2003$ & FB & \\
\hline \multicolumn{6}{|l|}{ Distillation } \\
\hline IBP & 359.6 & deg.F & ASTM D-86 & $3 / 7 / 2003$ & PW \\
\hline $5 \% \operatorname{Rec}$ & 405.3 & deg.F & & & \\
\hline $10 \% \operatorname{Rec}$ & 423.3 & deg.F & & & \\
\hline $20 \% \operatorname{Rec}$ & 448.4 & deg.F & & & \\
\hline $30 \%$ Rec & 469.6 & deg.F & & & \\
\hline $40 \%$ Rec & 488.1 & deg.F & & & \\
\hline $50 \%$ Rec & 507 & deg.F & & & \\
\hline $60 \%$ Rec & 525.9 & deg.F & & & \\
\hline $70 \% \operatorname{Rec}$ & 545.5 & deg.F & & & \\
\hline $80 \%$ Rec & 568.4 & deg.F & & & \\
\hline $90 \% \mathrm{Rec}$ & 599.7 & deg.F & & & \\
\hline $95 \%$ Rec & 629.4 & deg.F & & & \\
\hline FBP & 654.2 & deg.F & & & \\
\hline Recovery & 98.1 & $\%$ & & & \\
\hline Residue & 1.1 & $\%$ & & & \\
\hline Loss & 0.8 & $\%$ & & & \\
\hline Flash Point, PMCC & 148 & deg.F & ASTM D-93(A) & $3 / 4 / 2003$ & FB \\
\hline \multicolumn{6}{|l|}{ Hydrocarbon Type - FIA } \\
\hline Aromatics & 28.2 & $1 \mathrm{v} \%$ & ASTM D-1319 & $3 / 11 / 2003$ & FB \\
\hline Olefins & 0.7 & $1 \mathrm{v} \%$ & $3 / 11 / 2003$ & FB & \\
\hline Saturates & 71.1 & $1 \mathrm{v} \%$ & $3 / 11 / 2003$ & FB & \\
\hline Hydrogen Content & 12.98 & $w t \%$ & ASTM D-5291M & $3 / 5 / 2003$ & QTI* \\
\hline Kinematic Viscosity@40 deg.C & 2.445 & $\mathrm{cSt}$ & ASTM D-445 & $3 / 12 / 2003$ & $\mathrm{OE}$ \\
\hline Specific Gravity & 0.8488 & (a) 60 deg.F & ASTM D-1298 & $3 / 10 / 2003$ & GLC \\
\hline Total Sulfur & 0.0413 & $w t \%$ & ASTM D-4294 & $3 / 6 / 2003$ & RMT \\
\hline
\end{tabular}


Table C-4: Kroger Fuel Analytical Report

\begin{tabular}{|c|c|c|c|c|c|}
\hline \multicolumn{6}{|l|}{ Analytical Report } \\
\hline Sample Number: & $130287-003$ & Sample ID: & Kroger D2 & & \\
\hline Sample Date: & $1 / 17 / 2003$ & Description: & & & \\
\hline Test & Result & Units & Method & Date & Analyst \\
\hline API Gravity@60 Deg. F & 36.3 & deg.API & ASTM D-1298 & $3 / 4 / 2003$ & $\mathrm{FB}$ \\
\hline Carbon & 86.88 & $\mathrm{wt} \%$ & ASTM D-5291M & $3 / 5 / 2003$ & QTI* \\
\hline Cetane Index, Calculated & 46.3 & ASTM D-976 & $3 / 12 / 2003$ & GLC & \\
\hline Cetane Number & 45.4 & ASTM D-613 & $3 / 6 / 2003$ & FB & \\
\hline \multicolumn{6}{|l|}{ Distillation } \\
\hline IBP & 359.1 & deg.F & ASTM D-86 & $3 / 7 / 2003$ & PW \\
\hline $5 \% \operatorname{Rec}$ & 388.4 & deg.F & & & \\
\hline $10 \%$ Rec & 404.3 & deg.F & & & \\
\hline $20 \%$ Rec & 427.7 & deg.F & & & \\
\hline $30 \%$ Rec & 447.1 & deg.F & & & \\
\hline $40 \%$ Rec & 467.8 & deg.F & & & \\
\hline $50 \%$ Rec & 488.3 & deg.F & & & \\
\hline $60 \%$ Rec & 508.8 & deg.F & & & \\
\hline $70 \% \operatorname{Rec}$ & 531.7 & deg.F & & & \\
\hline $80 \%$ Rec & 560 & deg.F & & & \\
\hline $90 \% \operatorname{Rec}$ & 597 & deg.F & & & \\
\hline $95 \% \operatorname{Rec}$ & 629.8 & deg.F & & & \\
\hline FBP & 653.9 & deg.F & & & \\
\hline Recovery & 98.1 & $\%$ & & & \\
\hline Residue & 1.2 & $\%$ & & & \\
\hline Loss & 0.7 & $\%$ & & & \\
\hline Flash Point, PMCC & 146 & deg.F & ASTM D-93(A) & $3 / 4 / 2003$ & FB \\
\hline \multicolumn{6}{|l|}{ Hydrocarbon Type - FIA } \\
\hline Aromatics & 26.8 & $1 \mathrm{v} \%$ & ASTM D-1319 & $3 / 11 / 2003$ & FB \\
\hline Olefins & 0.8 & $1 \mathrm{v} \%$ & $3 / 11 / 2003$ & FB & \\
\hline Saturates & 72.4 & $1 \mathrm{v} \%$ & $3 / 11 / 2003$ & FB & \\
\hline Hydrogen Content & 13.1 & wt $\%$ & ASTM D-5291M & $3 / 5 / 2003$ & QTI* \\
\hline Kinematic Viscosity@40 deg. C & 2.17 & $\mathrm{cSt}$ & ASTM D-445 & $3 / 12 / 2003$ & $\mathrm{OE}$ \\
\hline Specific Gravity & 0.8433 & (a) 60 deg.F & ASTM D-1298 & $3 / 10 / 2003$ & FLX* \\
\hline Total Sulfur & 0.0395 & $\mathrm{wt} \%$ & ASTM D-4294 & $3 / 6 / 2003$ & \\
\hline
\end{tabular}


Table C-5: Guttman Fuel Analytical Report

Analytical Report

Sample Number:

Sample Date:

Test

API Gravity@60 Deg. F Carbon

Cetane Index, Calculated

Cetane Number

Distillation

IBP

$5 \% \operatorname{Rec}$

$10 \% \operatorname{Rec}$

$20 \% \operatorname{Rec}$

$30 \% \operatorname{Rec}$

$40 \% \operatorname{Rec}$

$50 \% \operatorname{Rec}$

$60 \% \operatorname{Rec}$

$70 \% \operatorname{Rec}$

$80 \%$ Rec

$90 \% \operatorname{Rec}$

95\% Rec

FBP

Recovery

Residue

Loss

Flash Point, PMCC

Hydrocarbon Type - FIA

Aromatics

Olefins

Saturates

Hydrogen Content

Kinematic Viscosity@ 40 deg. C

Specific Gravity

Total Sulfur

$\begin{array}{ccccc}\begin{array}{c}\text { 130287-005 } \\ \text { 1/22/2003 }\end{array} & \begin{array}{c}\text { Sample ID: } \\ \text { Description: }\end{array} & \text { Guttman Fuel Test } & & \\ \text { Result } & \text { Units } & \text { Method } & \text { Date } & \text { Analyst } \\ 43.2 & \text { deg.API } & \text { ASTM D-1298 } & 3 / 4 / 2003 & \text { FB } \\ 85.93 & \text { wt } \% & \text { ASTM D-5291M } & 3 / 5 / 2003 & \text { QTI* } \\ 57.6 & \text { ASTM D-976 } & 3 / 12 / 2003 & \text { GLC } & \\ 58.4 & \text { ASTM D-613 } & 3 / 6 / 2003 & \text { FB } & \end{array}$

354.2

375.7

385.2

405.5

427.3

450.5

480.9

509.6

537.8

564.5

590.9

608.5

622.5

98

1.3

0.7

148.2

12.8

1.1

86.1

14.2

2.12

0.81

0.0407
deg.F

deg.F

deg.F

deg.F

deg.F

deg.F

deg.F

deg.F

deg.F

deg.F

deg.F

deg.F

deg.F

$\%$

$\%$

$\%$

deg.F

lv $\%$

1v\%

$1 \mathrm{v} \%$

wt $\%$

$\mathrm{cSt}$

(a) 60 deg.F

$w t \%$

$\begin{array}{ccc}\text { ASTM D-93(A) } & 3 / 4 / 2003 & \text { FB } \\ & & \\ \text { ASTM D-1319 } & 3 / 11 / 2003 & \text { FB } \\ 3 / 11 / 2003 & \text { FB } & \\ 3 / 11 / 2003 & \text { FB } & \\ \text { ASTM D-5291M } & 3 / 5 / 2003 & \text { QTI* } \\ \text { ASTM D-445 } & 3 / 12 / 2003 & \text { OE } \\ \text { ASTM D-1298 } & 3 / 10 / 2003 & \text { GLC } \\ \text { ASTM D-4294 } & 3 / 6 / 2003 & \text { RMT }\end{array}$




\section{Appendix D. Results of Operating Condition Tests}

Table D-1: Results of Diesel Engine Work and Emission Measurements for Fuel Temperature Study on SAB2BM Cycles on WVU DC Dynamometer

$\begin{array}{rcc}\text { Sequence Number: } & \text { SAB2BM02 } & \text { SAB2BM03 } \\ \text { Description: } & \text { Hot Fuel } & \text { Cold Fuel } \\ \text { Integrated Emissions } & \text { g/Bhp-Hr } & \text { g/Bhp-Hr } \\ \text { HC } & 0.156 & 0.166 \\ \text { CO } & 0.747 & 0.742 \\ \text { CO }_{2} & 574 & 573 \\ \text { NO }_{\mathbf{x}} & 3.78 & 3.85 \\ \mathbf{P M} & 0.0412 & 0.0486\end{array}$

$\begin{array}{rrr}\text { Actual Work (Bhp-Hr) } & 35.47 & 35.48 \\ \text { BSFC (lb/Bhp-Hr) } & 0.425 & 0.412 \\ \text { Fuel Consumption (lb) } & 15.08 & 14.61\end{array}$

$\begin{array}{rccc} & \begin{array}{c}\text { Average } \\ \text { g/Bhp-Hr }\end{array} & \begin{array}{c}\text { Std Dev } \\ \text { g/Bhp-Hr }\end{array} & \begin{array}{c}\text { COV } \\ \mathbf{( \% )}\end{array} \\ \mathbf{H C} & 0.161 & 0.007 & 4.39 \\ \mathbf{C O} & 0.745 & 0.004 & 0.47 \\ \mathbf{C O}_{2} & 574 & 1.03 & 0.18 \\ \text { NO}_{\mathbf{x}} & 3.818 & 0.051 & 1.33 \\ \mathbf{P M} & 0.045 & 0.005 & 11.71 \\ & & & \\ \text { Actual Work (Bhp-Hr) } & 35.48 & 0.007 & 0.02 \\ \text { BSFC (lb/Bhp-Hr) } & 0.419 & 0.009 & 2.20 \\ \text { Fuel Consumption (lb) } & 14.85 & 0.332 & 2.24\end{array}$


Table D-2: Results of Diesel Engine Work and Emission Measurements for Intercooler Temperature Study on SAB2BM Cycles on WVU DC Dynamometer

\begin{tabular}{|c|c|c|c|}
\hline $\begin{array}{r}\text { Sequence Number: } \\
\text { Description: }\end{array}$ & $\begin{array}{c}\text { SAB2BM04 } \\
\text { Cold Intercooler }\end{array}$ & $\begin{array}{c}\text { SAB2BM05 } \\
\text { Hot Intercooler }\end{array}$ & \\
\hline Integrated Emissions & g/Bhp-Hr & g/Bhp-Hr & \\
\hline HC & 0.182 & 0.154 & \\
\hline $\mathrm{CO}$ & 0.713 & 0.793 & \\
\hline $\mathrm{CO}_{2}$ & 556 & 573 & \\
\hline $\mathbf{N O}_{x}$ & 3.77 & 3.98 & \\
\hline $\mathbf{P M}$ & 0.0469 & 0.0495 & \\
\hline Actual Work (Bhp-Hr) & 35.42 & 35.47 & \\
\hline BSFC (lb/Bhp-Hr) & 0.413 & 0.421 & \\
\hline Fuel Consumption (lb) & 14.64 & 14.92 & \\
\hline & $\begin{array}{l}\text { Average } \\
\text { g/Bhp-Hr }\end{array}$ & $\begin{array}{c}\text { Std Dev } \\
\text { g/Bhp-Hr }\end{array}$ & $\begin{array}{r}\mathrm{COV} \\
(\%)\end{array}$ \\
\hline $\mathrm{HC}$ & 0.168 & 0.020 & 11.79 \\
\hline $\mathbf{C O}$ & 0.753 & 0.057 & 7.51 \\
\hline $\mathrm{CO}_{2}$ & 564 & 12.40 & 2.20 \\
\hline $\mathbf{N O}_{\mathbf{x}}$ & 3.873 & 0.148 & 3.82 \\
\hline $\mathbf{P M}$ & 0.048 & 0.002 & 3.87 \\
\hline Actual Work (Bhp-Hr) & 35.45 & 0.035 & 0.10 \\
\hline BSFC (lb/Bhp-Hr) & 0.417 & 0.006 & 1.36 \\
\hline Fuel Consumption (lb) & 14.78 & 0.198 & 1.34 \\
\hline
\end{tabular}


Table D-3: Results of Diesel Engine Work and Emission Measurements for Intake Air Temperature Study on SAB2BM Cycles on WVU DC Dynamometer

\begin{tabular}{|c|c|c|c|}
\hline $\begin{array}{r}\text { Sequence Number: } \\
\text { Descrintion: }\end{array}$ & $\begin{array}{c}\text { SAB2BM06 } \\
\text { Cold Intake Air }\end{array}$ & $\begin{array}{c}\text { SAB2BM07 } \\
\text { Hot Intake Air }\end{array}$ & \\
\hline Integrated Emissions & g/Bhp-Hr & g/Bhp-Hr & \\
\hline HC & 0.183 & 0.149 & \\
\hline $\mathbf{C O}$ & 0.75 & 0.785 & \\
\hline $\mathrm{CO}_{2}$ & 577 & 581 & \\
\hline $\mathrm{NO}_{\mathrm{x}}$ & 3.71 & 4.16 & \\
\hline $\mathbf{P M}$ & 0.0580 & 0.0439 & \\
\hline Actual Work (Bhp-Hr) & 35.53 & 35.49 & \\
\hline BSFC (lb/Bhp-Hr) & 0.417 & 0.42 & \\
\hline Fuel Consumption (lb) & 14.8 & 14.92 & \\
\hline & $\begin{array}{l}\text { Average } \\
\text { g/Bhp-Hr }\end{array}$ & $\begin{array}{c}\text { Std Dev } \\
\text { g/Bhp-Hr }\end{array}$ & $\begin{array}{r}\mathrm{COV} \\
(\%)\end{array}$ \\
\hline HC & 0.166 & 0.024 & 14.48 \\
\hline $\mathrm{CO}$ & 0.768 & 0.025 & 3.22 \\
\hline $\mathrm{CO}_{2}$ & 579 & 3.37 & 0.58 \\
\hline $\mathbf{N O}_{\mathbf{x}}$ & 3.936 & 0.315 & 8.01 \\
\hline $\mathbf{P M}$ & 0.051 & 0.010 & 19.58 \\
\hline Actual Work (Bhp-Hr) & 35.51 & 0.028 & 0.08 \\
\hline BSFC (lb/Bhp-Hr) & 0.419 & 0.002 & 0.51 \\
\hline Fuel Consumption (lb) & 14.86 & 0.085 & 0.57 \\
\hline
\end{tabular}


Table D-4: Results of Diesel Engine Work and Emission Measurements for Engine Restriction Study on SAB2BM Cycles for on WVU DC Dynamometer

\begin{tabular}{|c|c|c|c|}
\hline $\begin{array}{r}\text { Sequence Number: } \\
\text { Description: } \\
\text { Integrated Emissions }\end{array}$ & $\begin{array}{c}\text { SAB2BM08 } \\
\text { Low Restriction } \\
\text { g/Bhp-Hr }\end{array}$ & $\begin{array}{c}\text { SAB2BM09 } \\
\text { High Restriction } \\
\text { g/Bhp-Hr }\end{array}$ & \\
\hline HC & 0.184 & 0.136 & \\
\hline $\mathbf{C O}$ & 0.729 & 0.8 & \\
\hline $\mathrm{CO}_{2}$ & 581 & 581 & \\
\hline $\mathbf{N O}_{\mathrm{x}}$ & 3.83 & 3.74 & \\
\hline PM & 0.0417 & 0.0437 & \\
\hline Actual Work (Bhp-Hr) & 35.42 & 35.47 & \\
\hline BSFC (lb/Bhp-Hr) & 0.413 & 0.419 & \\
\hline Fuel Consumption (lb) & 14.64 & 14.87 & \\
\hline & $\begin{array}{l}\text { Average } \\
\text { g/Bhp-Hr }\end{array}$ & $\begin{array}{l}\text { Std Dev } \\
\text { g/Bhp-Hr }\end{array}$ & $\begin{array}{r}\mathrm{COV} \\
(\%)\end{array}$ \\
\hline HC & 0.160 & 0.034 & 21.21 \\
\hline $\mathbf{C O}$ & 0.765 & 0.050 & 6.57 \\
\hline $\mathrm{CO}_{2}$ & 581 & 0.05 & 0.01 \\
\hline $\mathbf{N O}_{\mathbf{x}}$ & 3.787 & 0.067 & 1.77 \\
\hline $\mathbf{P M}$ & 0.043 & 0.001 & 3.36 \\
\hline Actual Work (Bhp-Hr) & 35.45 & 0.035 & 0.10 \\
\hline BSFC (lb/Bhp-Hr) & 0.416 & 0.004 & 1.02 \\
\hline Fuel Consumption (lb) & 14.76 & 0.163 & 1.10 \\
\hline
\end{tabular}




\section{Appendix E. Data Correlation Analysis}

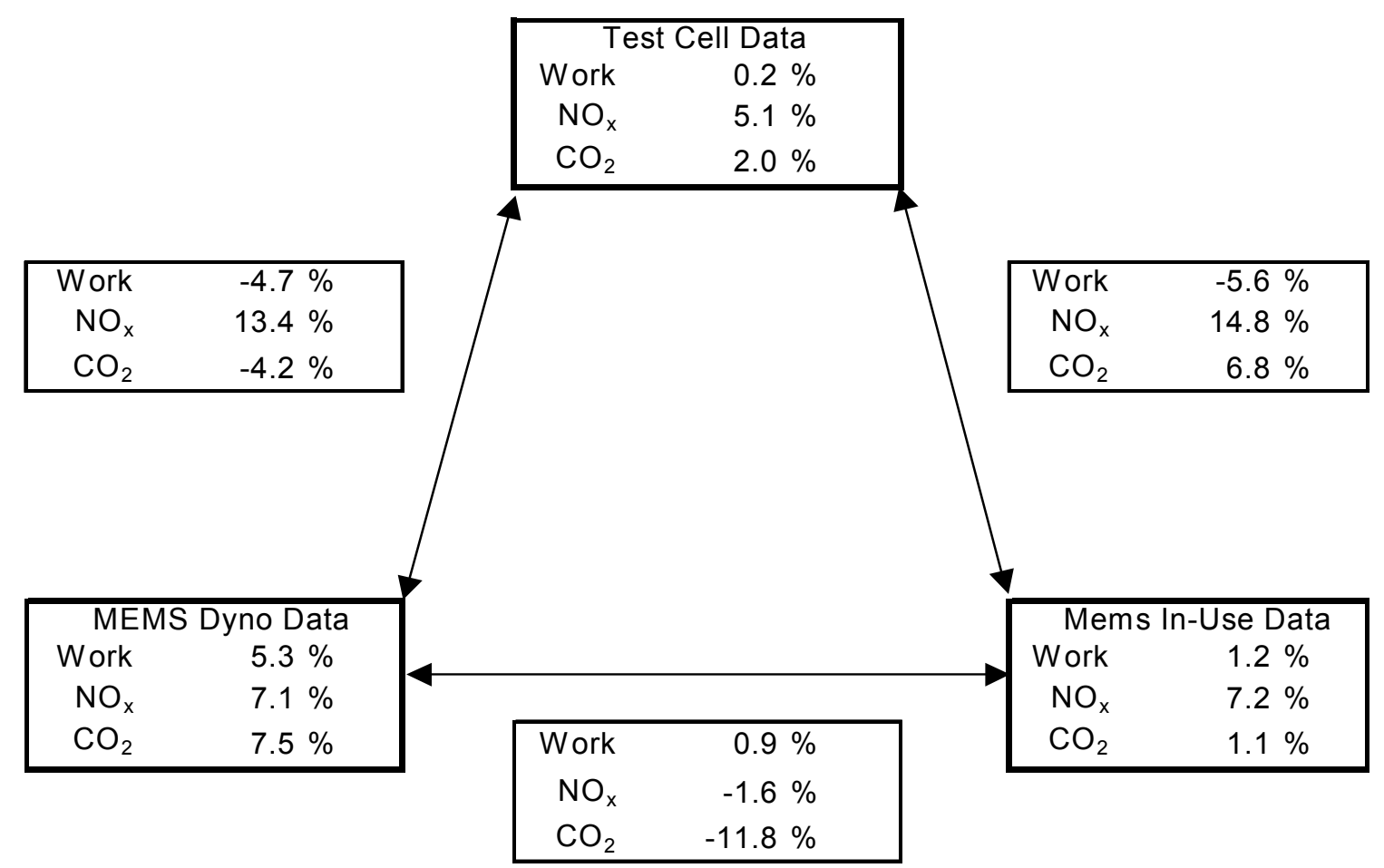

Figure E-1: Vehicle A Correlation Study Results

Table E-1: Vehicle A Integrated Data From Test Record

$\begin{array}{llll}\text { Vehicle A } & \text { NO }_{\mathrm{x}} & \mathrm{CO}_{2} & \text { Work }\end{array}$

\begin{tabular}{cccc} 
SAB2BM Cycle & (g/Bhp-Hr)(g/Bhp-Hr) $(\mathbf{B h p}-\mathbf{H r})$ \\
\hline \hline MEMS On-road & & & \\
Route 1 & 5.1 & 428.1 & 129.8 \\
Route 2 & 5.5 & 425.9 & 130.4 \\
Route 3 & 5.2 & 430.8 & 131.4 \\
Variation (\%) & 7.2 & 1.1 & 1.2 \\
\hline Mems Test Cell & & & \\
Route 1 & 5.0 & 491.8 & 126.4 \\
Route 2 & 5.1 & 454.9 & 133.3 \\
Route 3 & 5.4 & 489.4 & 126.3 \\
Variation (\%) & 7.1 & 7.5 & 5.3 \\
\hline Laboratory Data & & & \\
Route 1 & 5.8 & 465.0 & 122.9 \\
Route 2 & 6.1 & 456.9 & 122.9 \\
Route 3 & 6.1 & 455.8 & 123.1 \\
Variation (\%) & 5.1 & 2.0 & 0.2 \\
\hline
\end{tabular}




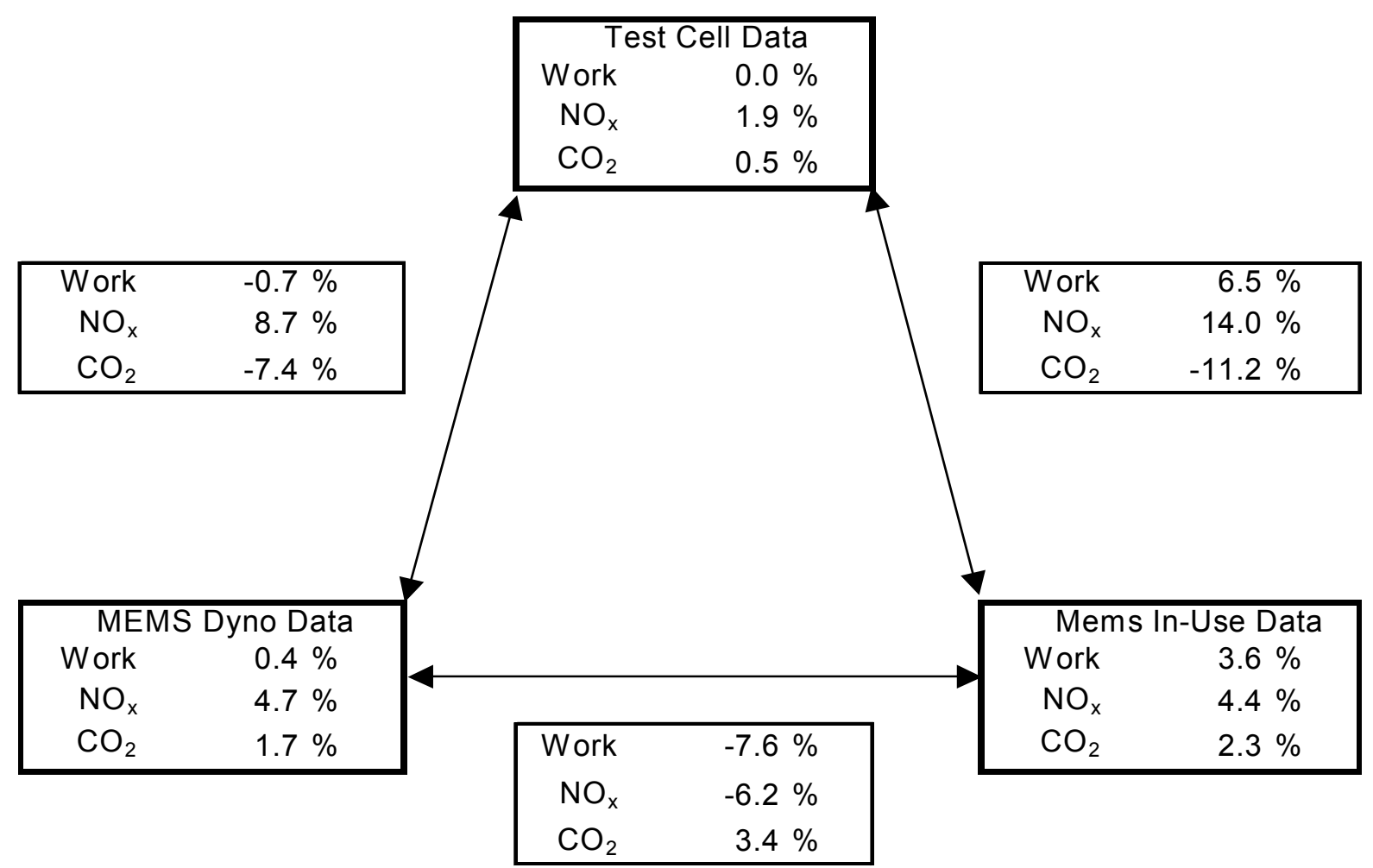

Figure E-2: Vehicle B Correlation Study Results

Table E-2: Vehicle B Integrated Data From Test Record

$\begin{array}{llll}\text { Vehicle B } & \text { NO }_{x} & \mathbf{C O}_{2} & \text { Work }\end{array}$ SAB2BM Cycle (g/Bhp-Hr)(g/Bhp-Hr) (Bhp-Hr)

\begin{tabular}{cccc}
\hline \hline MEMS On-road & & & \\
Route 1 & 7.1 & 522.8 & 110.7 \\
Route 2 & 7.3 & 516.2 & 112.8 \\
Route 3 & 7.0 & 528.1 & 114.9 \\
Variation (\%) & 4.4 & 2.3 & 3.6 \\
\hline Mems Test Cell & & & \\
Route 1 & 7.7 & 509.4 & 118.9 \\
Route 2 & 7.6 & 505.3 & 119.3 \\
Route 3 & 7.4 & 500.9 & 119.3 \\
Variation (\%) & 4.7 & 1.7 & 0.4 \\
\hline Laboratory Data & & & \\
Route 1 & 8.2 & 468.8 & 118.4 \\
Route 2 & 8.3 & 471.0 & 118.4 \\
Route 3 & 8.3 & 471.1 & 118.4 \\
Variation (\%) & 1.9 & 0.5 & 0.0 \\
\hline
\end{tabular}




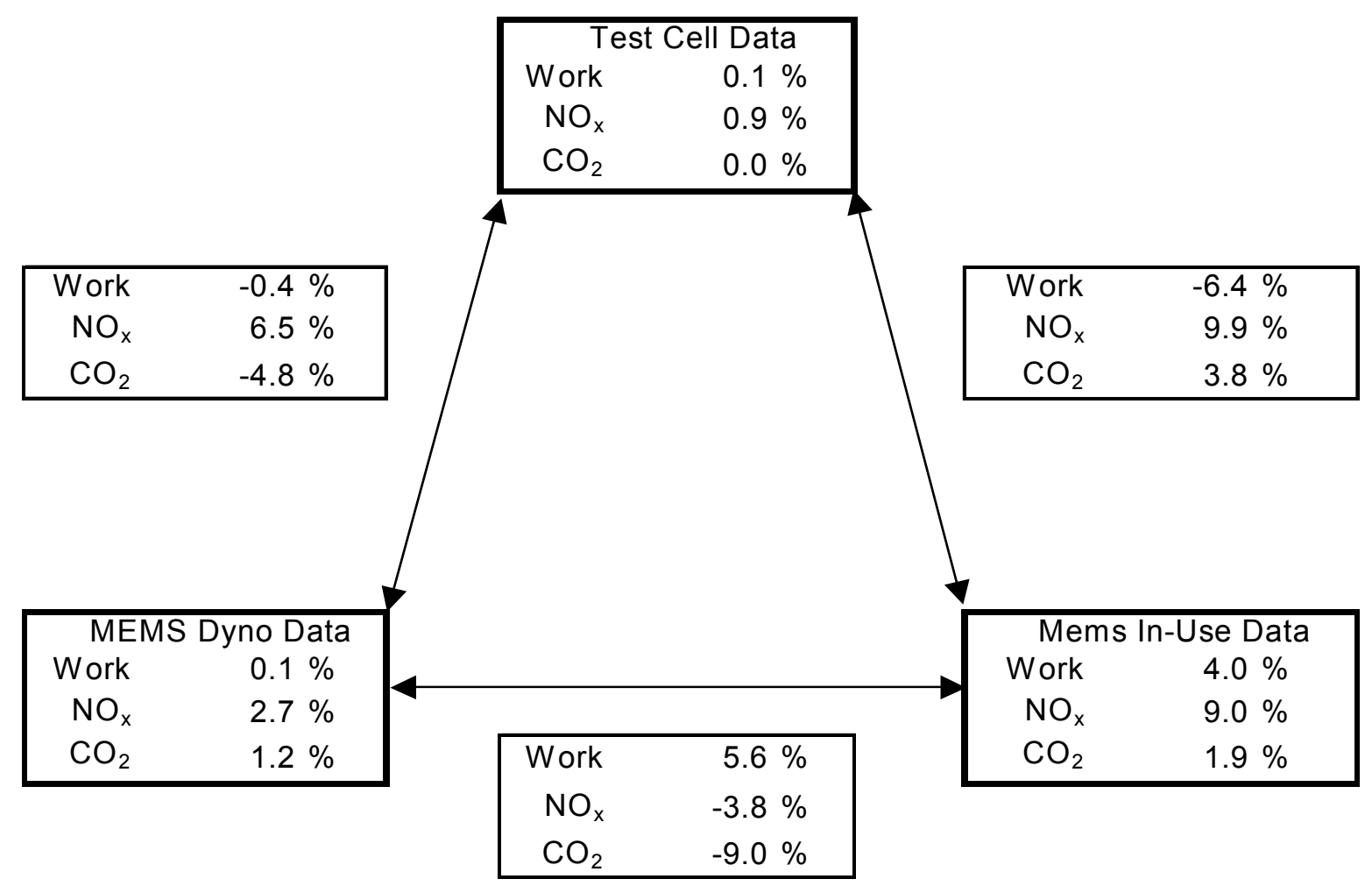

Figure E-3: Vehicle C Correlation Study Results

Table E-3: Vehicle C Integrated Data From Test Record

$\begin{array}{llll}\text { Vehicle } \mathrm{C} & \mathrm{NO}_{\mathrm{x}} & \mathrm{CO}_{2} & \text { Work }\end{array}$

SAB2BM Cycle (g/Bhp-Hr)(g/Bhp-Hr) (Bhp-Hr)

\begin{tabular}{cccc} 
MEMS On-road & & & \\
Route 1 & 4.4 & 461.4 & 134.8 \\
Route 2 & 4.1 & 470.3 & 136.9 \\
Route 3 & 4.0 & 462.2 & 140.4 \\
Variation (\%) & 9.0 & 1.9 & 4.0 \\
\hline Mems Test Cell & & & \\
Route 1 & 4.6 & 501.4 & 127.3 \\
Route 2 & 4.5 & 506.8 & 127.2 \\
Route 3 & 4.7 & 500.5 & 127.4 \\
Variation (\%) & 2.7 & 1.2 & 0.1 \\
\hline Laboratory Data & & & \\
Route 1 & 4.9 & 479.8 & 126.8 \\
Route 2 & 4.9 & 479.6 & 126.7 \\
Route 3 & 4.9 & 479.8 & 126.8 \\
Variation (\%) & 0.9 & 0.0 & 0.1 \\
\hline
\end{tabular}




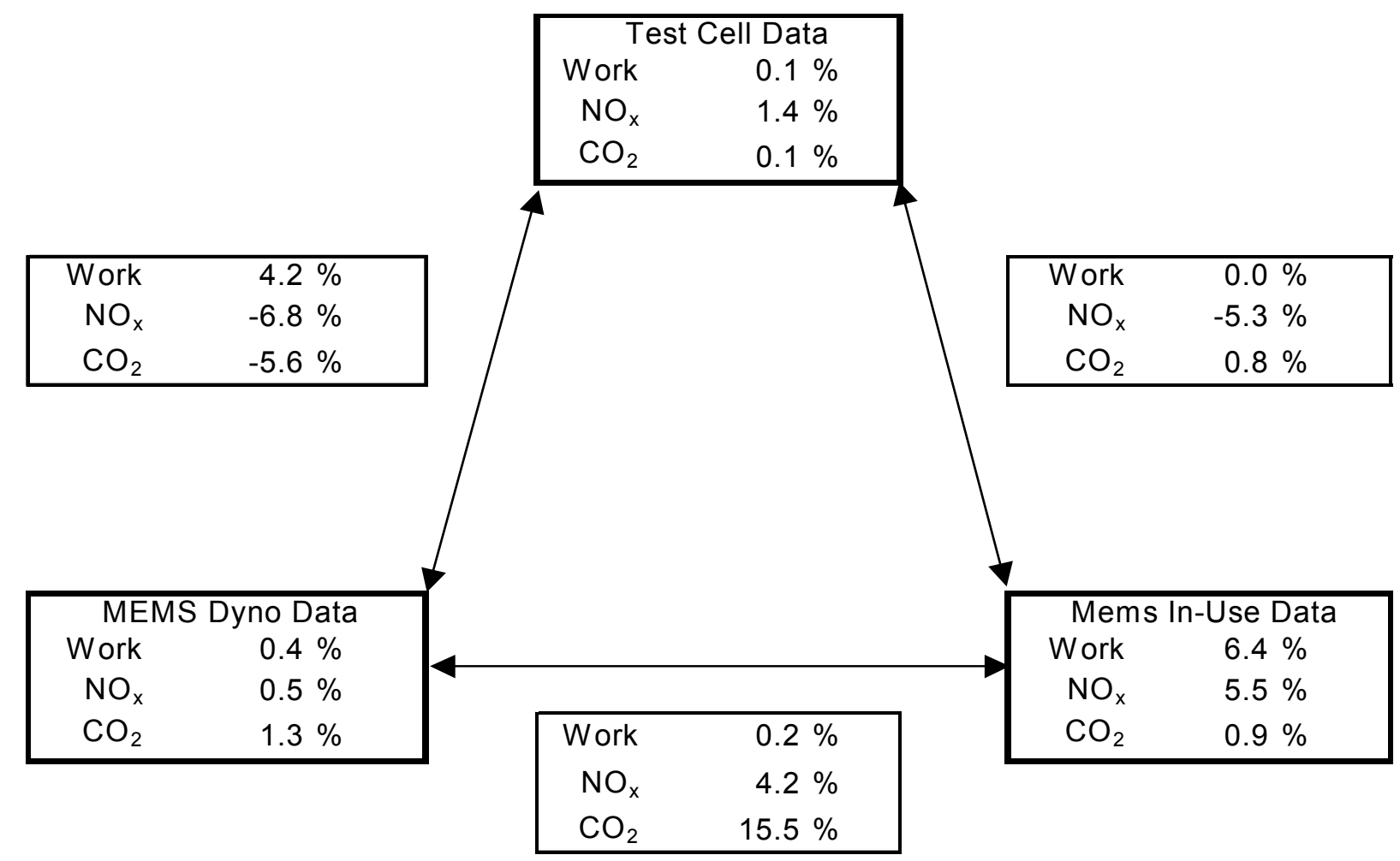

Figure E-4: Vehicle D Correlation Study Results

Table E-4: Vehicle D Integrated Data From Test Record

$\begin{array}{llll}\text { Vehicle D } & \mathrm{NO}_{\mathrm{x}} & \mathrm{CO}_{2} & \text { Work }\end{array}$

SAB2BM Cycle (g/Bhp-Hr)(g/Bhp-Hr) (Bhp-Hr)

\begin{tabular}{cccc}
\hline \hline MEMS On-road & & & \\
Route 1 & 4.7 & 701.1 & 35.6 \\
Route 2 & 4.8 & 706.3 & 35.6 \\
Route 3 & 5.0 & 700.2 & 38.0 \\
Variation (\%) & 5.5 & 0.9 & 6.4 \\
\hline Mems Test Cell & & & \\
Route 1 & 4.5 & 624.9 & 34.1 \\
Route 2 & 4.5 & 630.4 & 34.0 \\
Route 3 & 4.5 & 632.9 & 33.9 \\
Variation (\%) & 0.5 & 1.3 & 0.4 \\
\hline Laboratory Data & & & \\
Route 1 & 4.2 & 594.3 & 35.5 \\
Route 2 & 4.2 & 596.8 & 35.5 \\
Route 3 & 4.2 & 597.3 & 35.5 \\
Variation (\%) & 1.4 & 0.1 & 0.1 \\
\hline
\end{tabular}




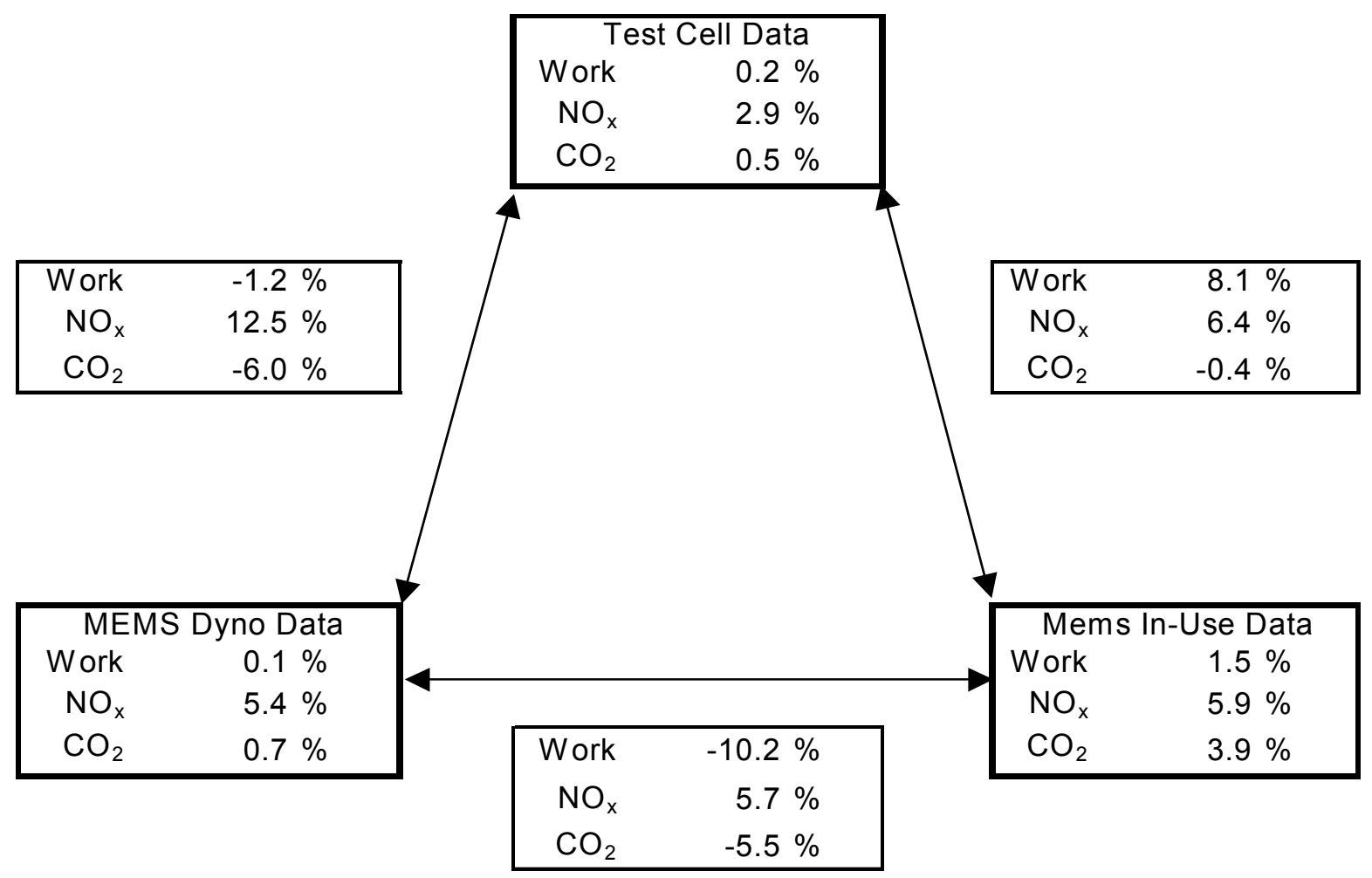

Figure E-5: Vehicle E Correlation Study Results

Table E-5: Vehicle E Integrated Data From Test Record

$\begin{array}{llll}\text { Vehicle E } & \mathbf{N O}_{\mathbf{x}} & \mathrm{CO}_{2} & \text { Work }\end{array}$ SAB2BM Cycle (g/Bhp-Hr)(g/Bhp-Hr) (Bhp-Hr)

\begin{tabular}{cccc}
\hline \hline MEMS On-road & & & \\
Route 1 & 6.2 & 438.2 & 126.0 \\
Route 2 & 6.3 & 438.8 & 124.1 \\
Route 3 & 6.6 & 456.2 & 125.9 \\
Variation (\%) & 5.9 & 3.9 & 1.5 \\
\hline Mems Test Cell & & & \\
Route 1 & 6.2 & 481.7 & 138.7 \\
Route 2 & 6.4 & 479.6 & 138.7 \\
Route 3 & 6.0 & 482.8 & 138.8 \\
Variation (\%) & 5.4 & 0.7 & 0.1 \\
\hline Laboratory Data & & & \\
Route 1 & 7.1 & 453.9 & 137.2 \\
Route 2 & 7.2 & 453.2 & 137.2 \\
Route 3 & 7.0 & 455.3 & 137.0 \\
Variation (\%) & 2.9 & 0.5 & 0.2 \\
\hline
\end{tabular}




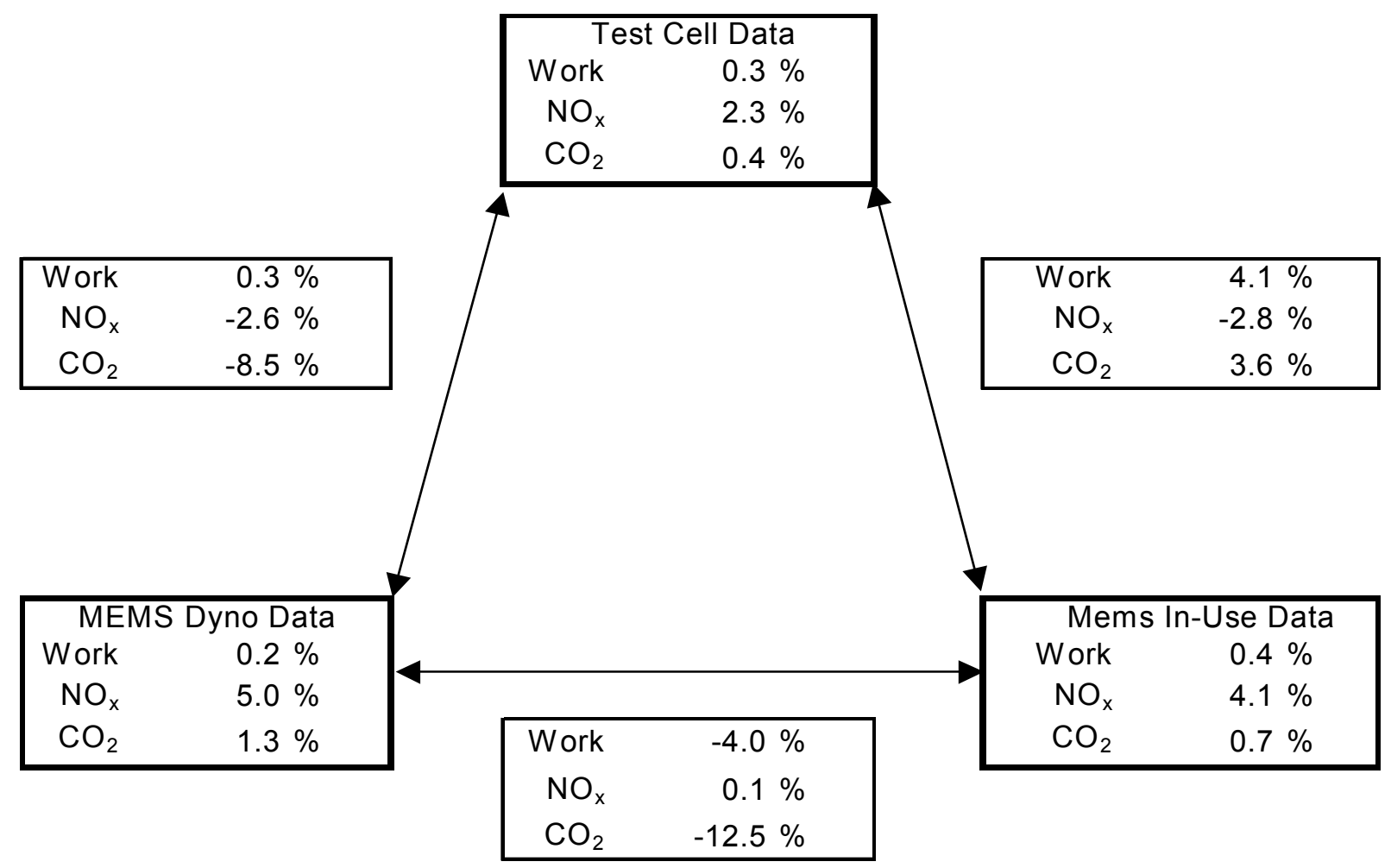

Figure E-6: Vehicle F Correlation Study Results

Table E-6: Vehicle F Integrated Data From Test Record

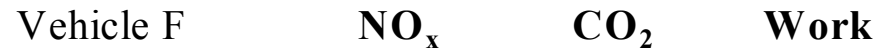

\begin{tabular}{cccc} 
SAB2BM Cycle & (g/Bhp-Hr)(g/Bhp-Hr) & (Bhp-Hr) \\
\hline \hline MEMS On-road & & & \\
Route 1 & 7.2 & 473.0 & 115.5 \\
Route 2 & - & - & - \\
Route 3 & 6.9 & 469.8 & 115.1 \\
Variation (\%) & 4.1 & 0.7 & 0.4 \\
\hline Mems Test Cell & & & \\
Route 1 & 7.1 & 531.2 & 119.8 \\
Route 2 & 6.8 & 524.1 & 119.7 \\
Route 3 & 6.7 & 530.4 & 119.6 \\
Variation (\%) & 5.0 & 1.3 & 0.2 \\
\hline Laboratory Data & & & \\
Route 1 & 6.7 & 486.4 & 119.9 \\
Route 2 & 6.8 & 488.2 & 120.1 \\
Route 3 & 6.6 & 487.0 & 120.2 \\
Variation (\%) & 2.3 & 0.4 & 0.3 \\
\hline
\end{tabular}




\section{Appendix F. Continuous On-Road and Test Cell Data}

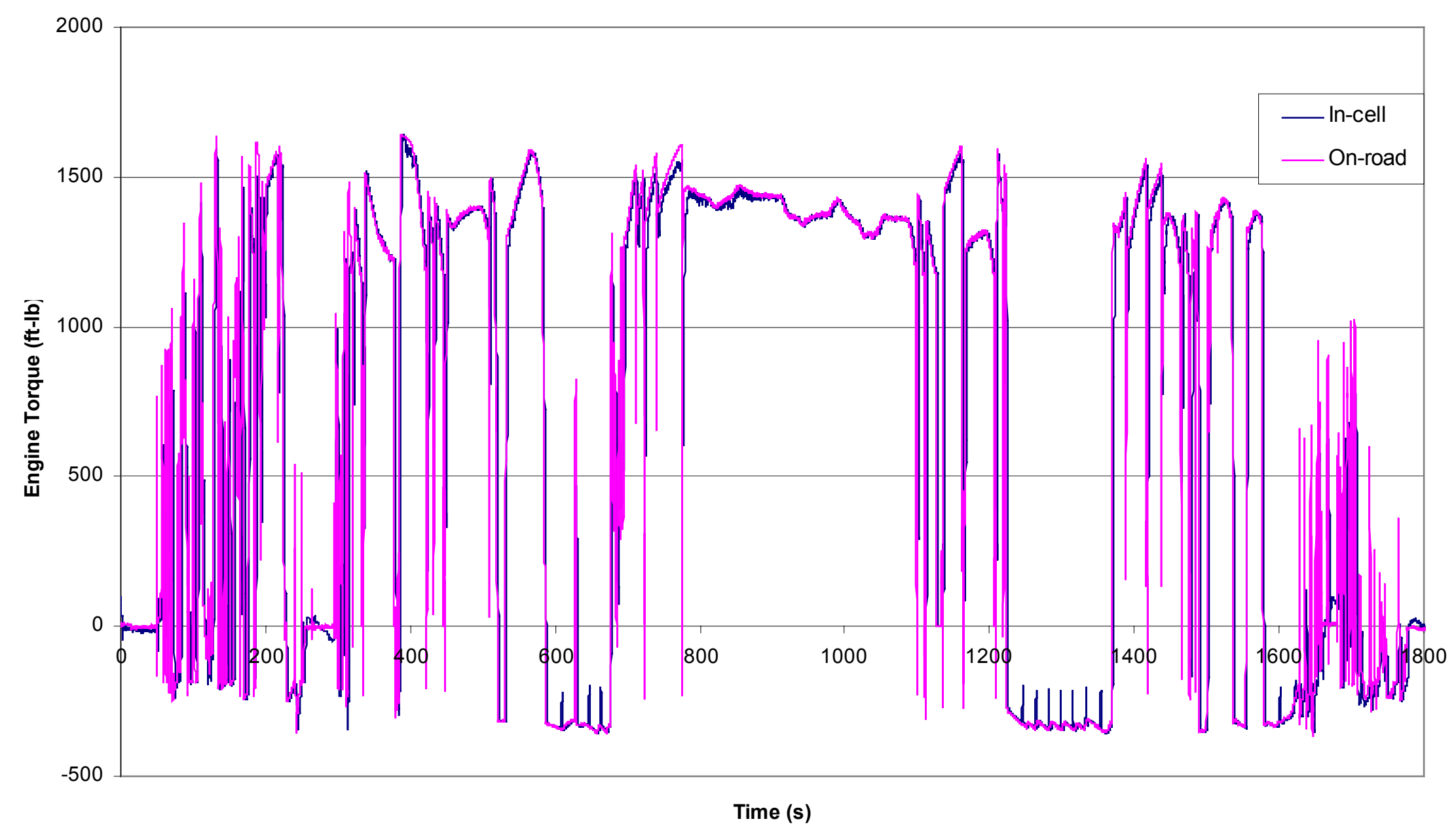

Figure F-1: Continuous Torque In-use Versus In-cell Sab2BM Comparison 


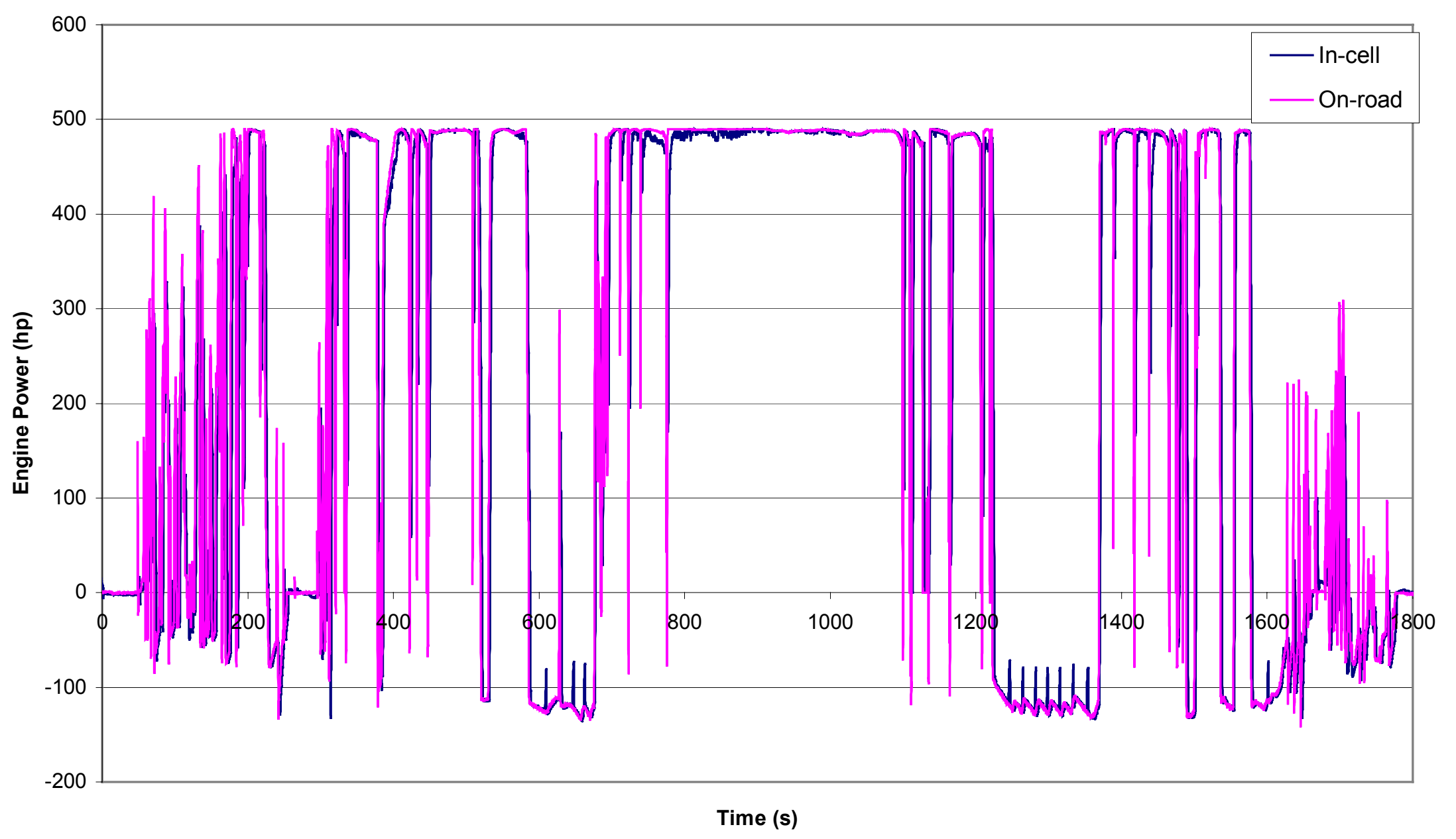

Figure F-2: Continuous Power In-use Versus In-cell Sab2BM Comparison 


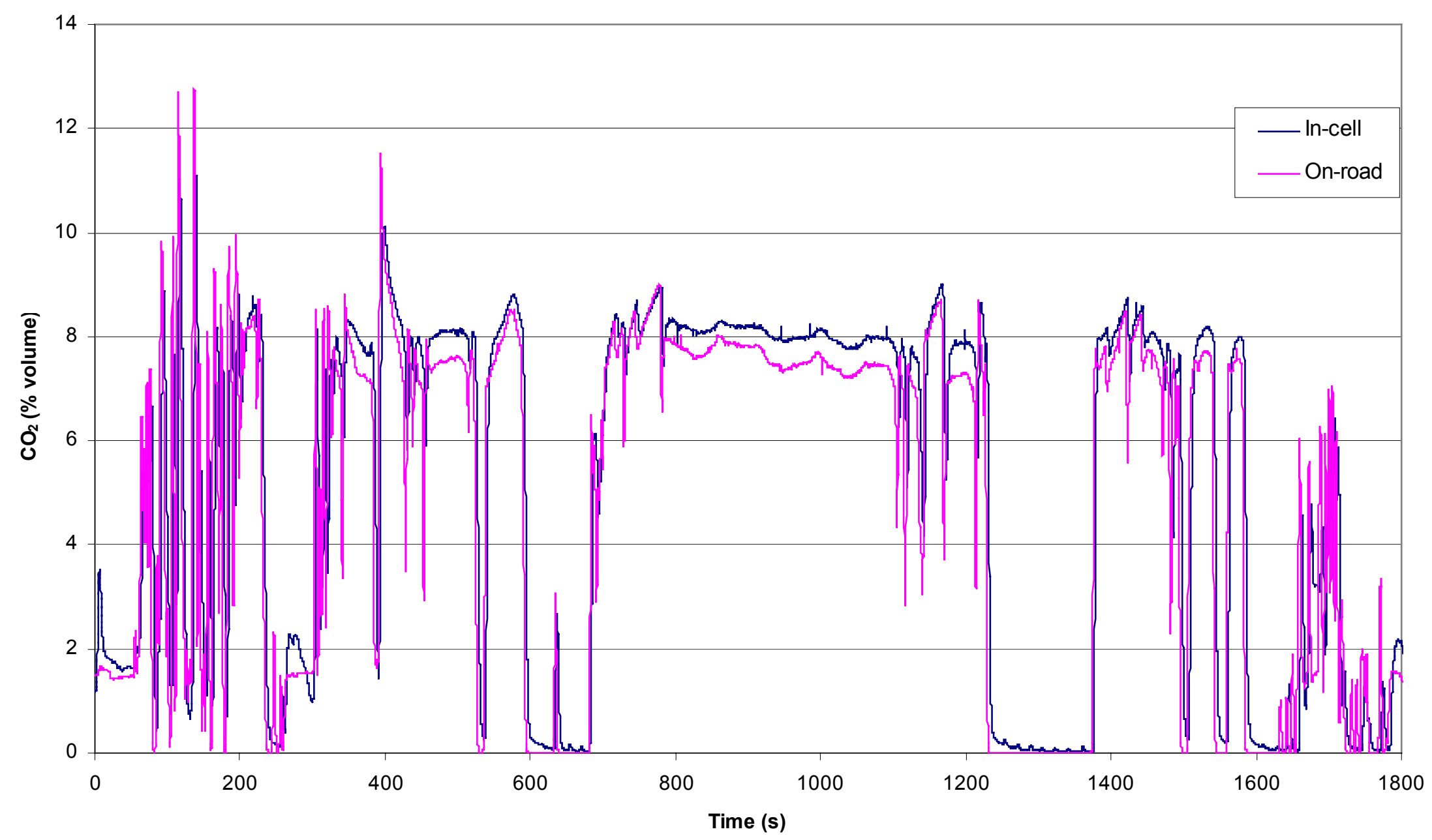

Figure F-3: Continuous $\mathrm{CO}_{2}$ In-use Versus In-cell Sab2BM Comparison 


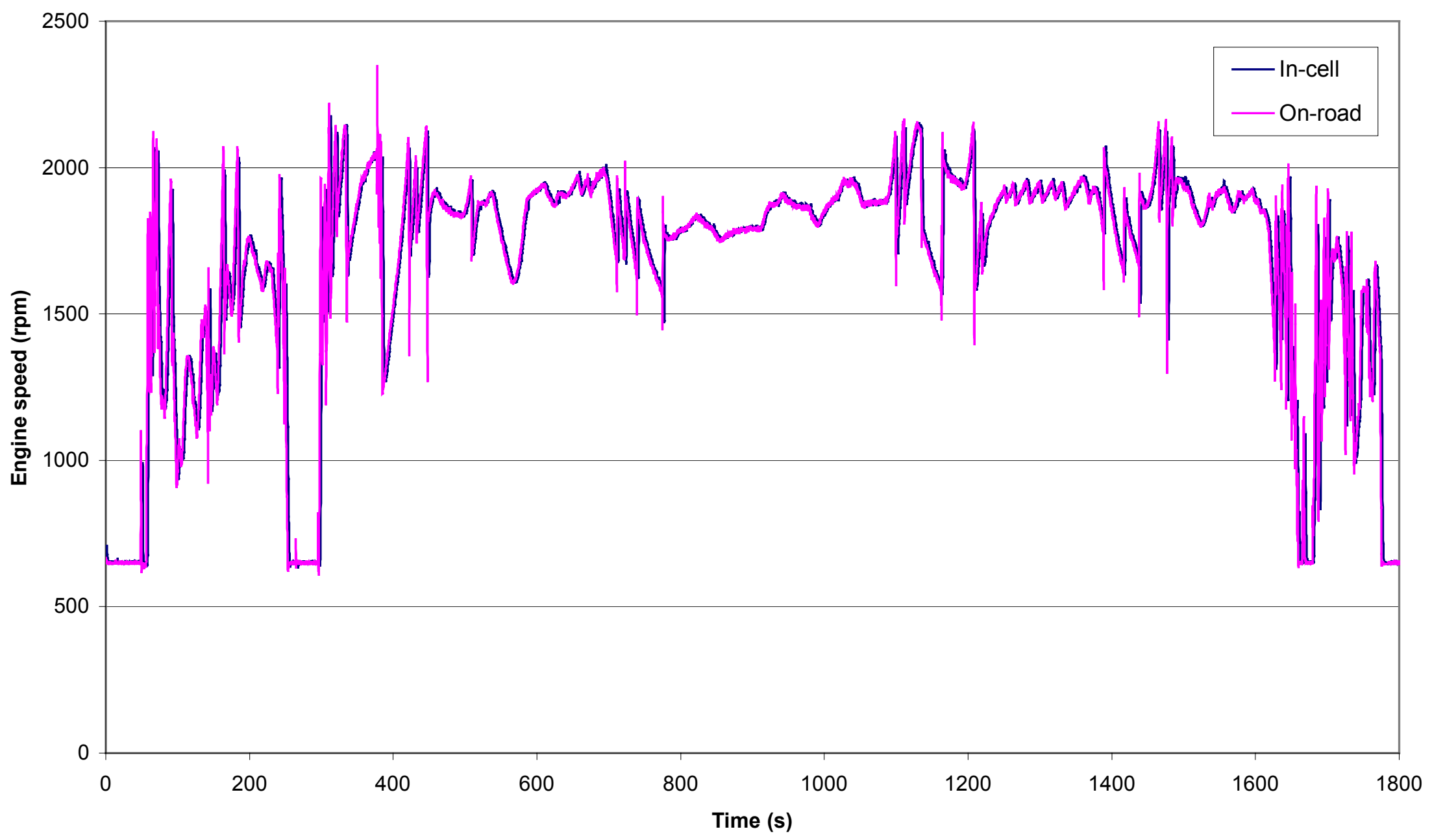

Figure F-4: Continuous Engine Speed In-use Versus In-cell Sab2BM Comparison 


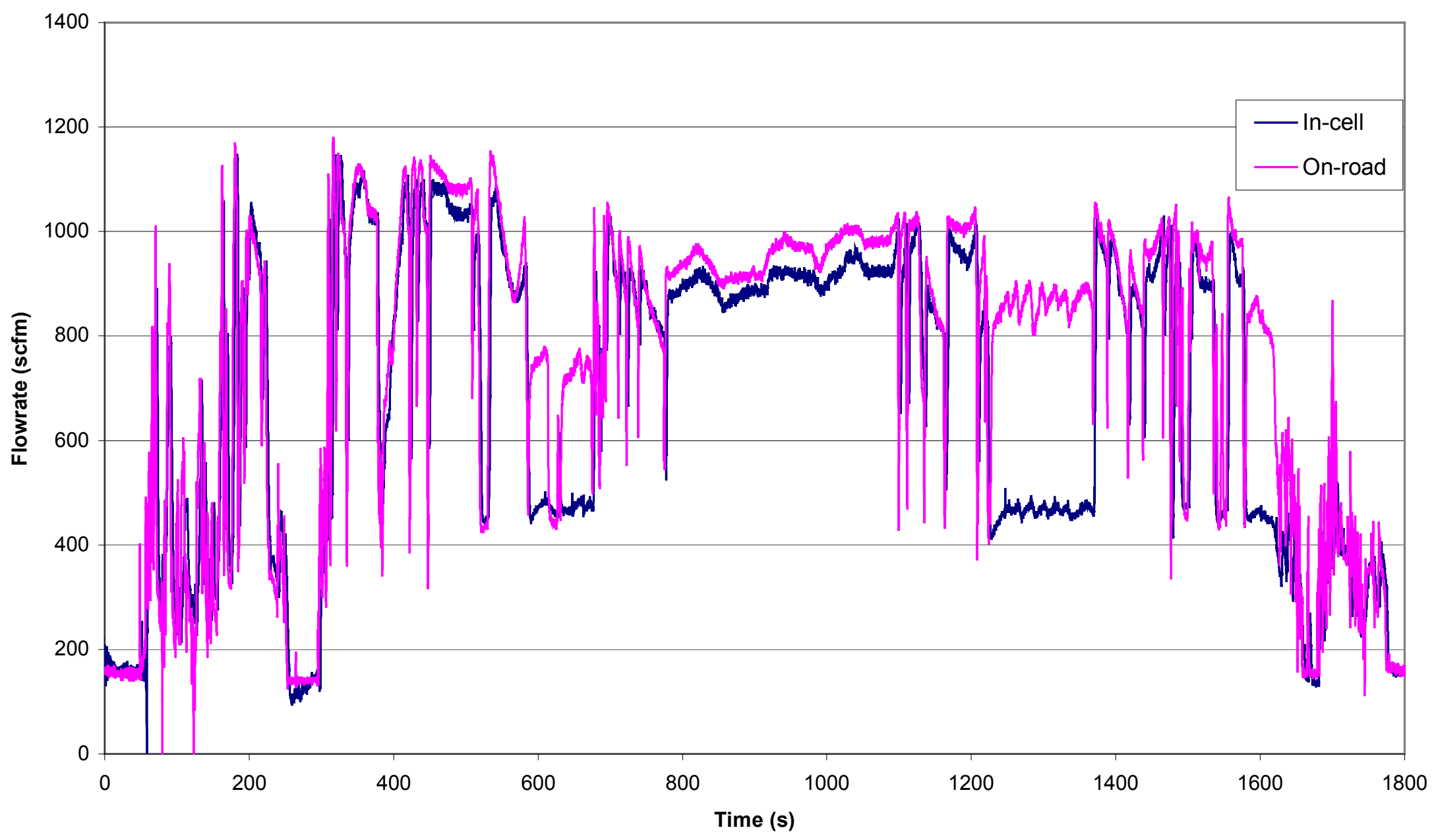

Figure F-5: Continuous Exhaust Flowrate In-use Versus In-cell Sab2BM Comparison 


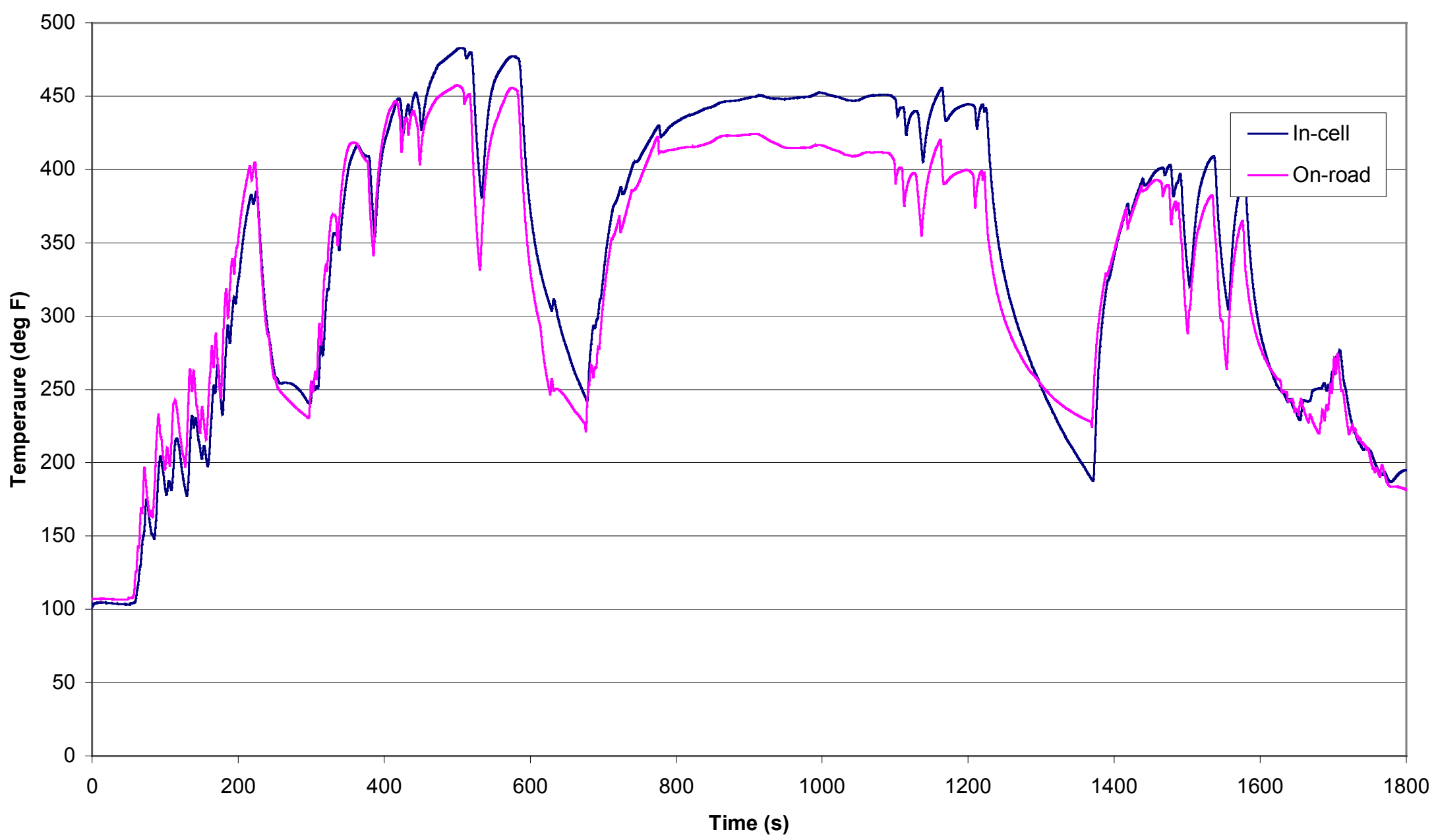

Figure F-6: Continuous Exhaust Temperature In-use Versus In-cell Sab2BM Comparison 


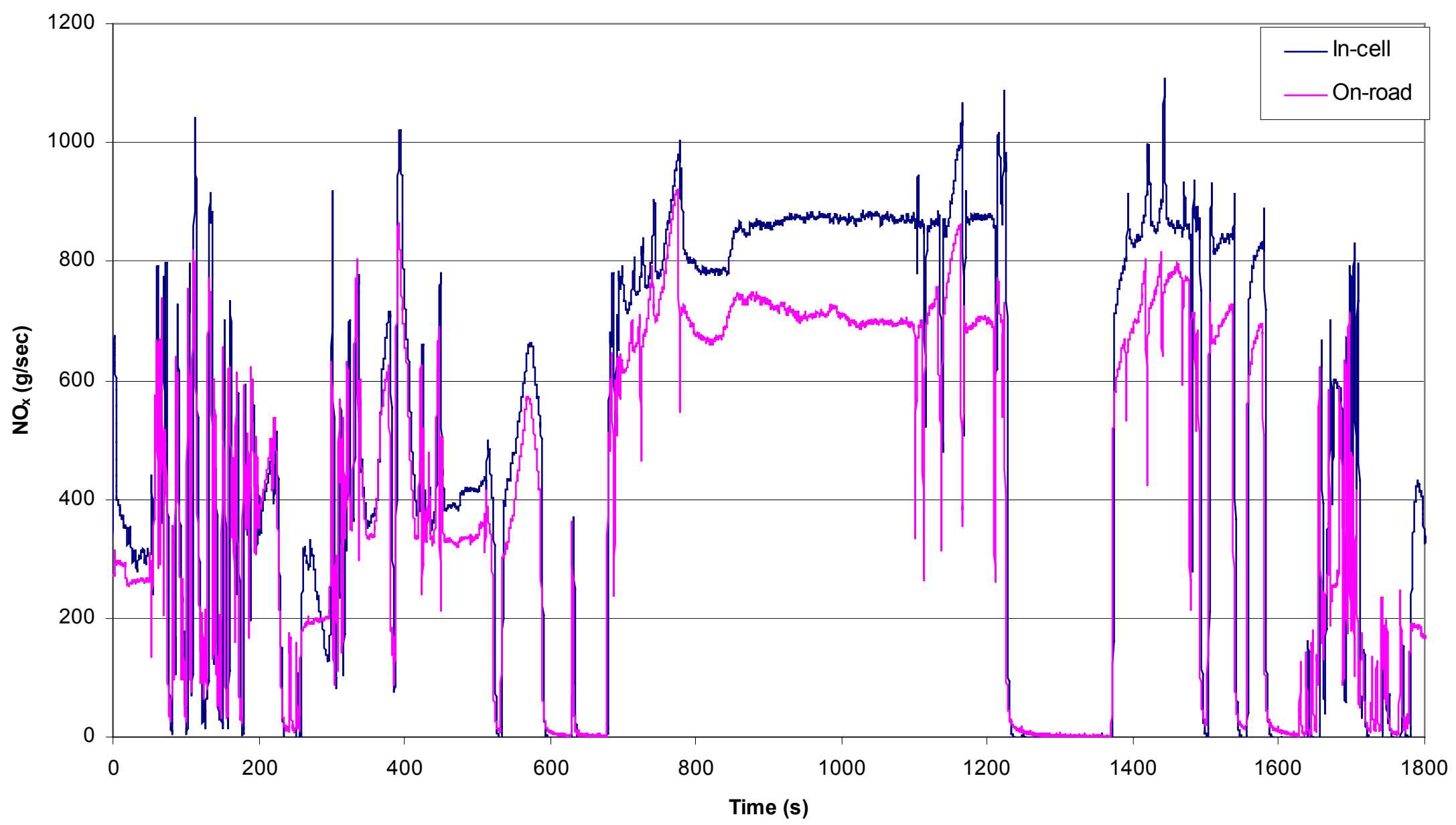

Figure F-7: Uncorrected Continuous NO$_{x}$ Emission In-use Versus In-cell Sab2BM 


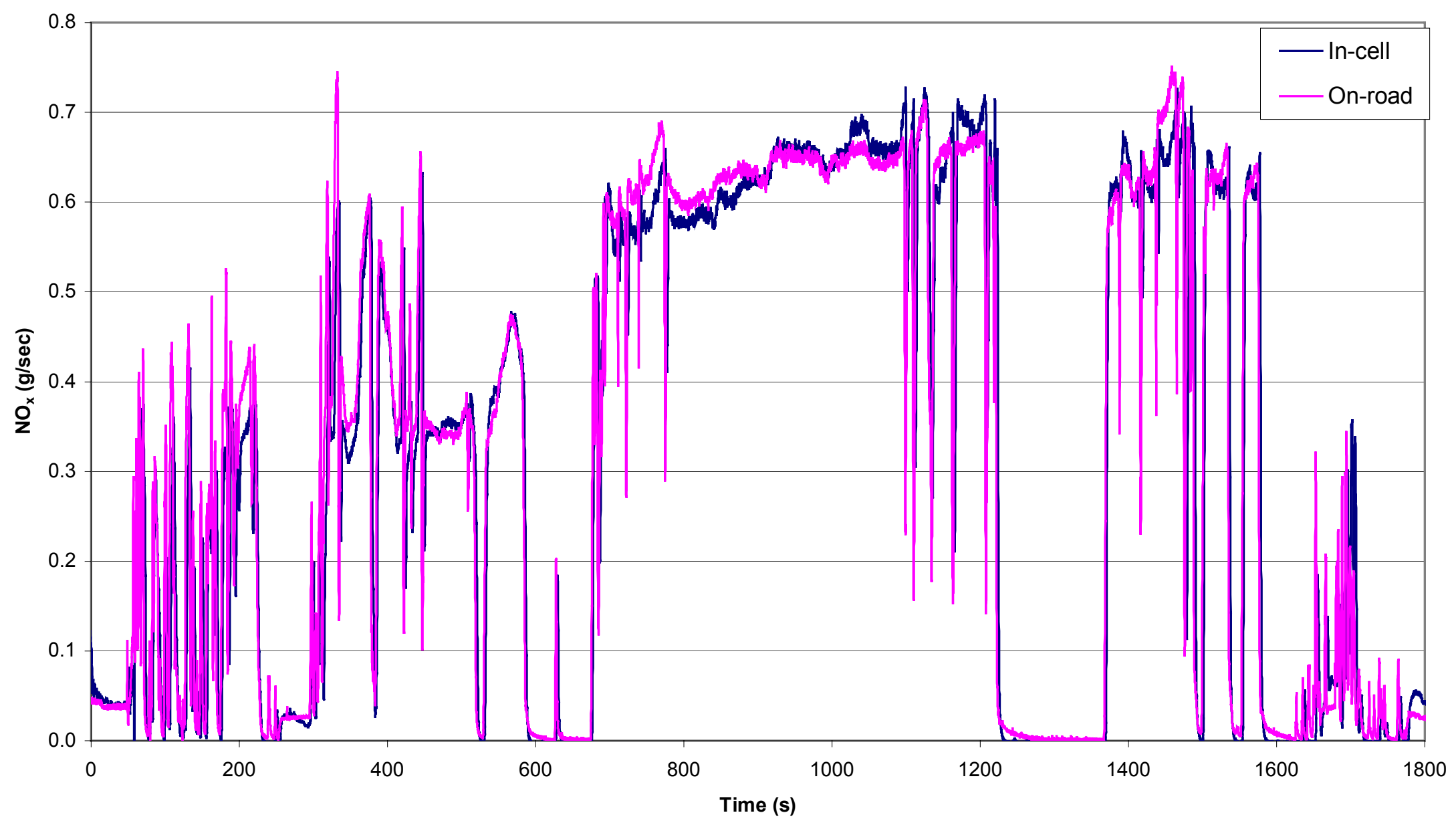

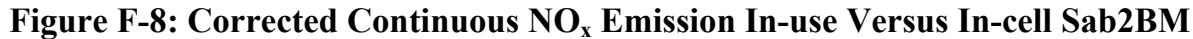

